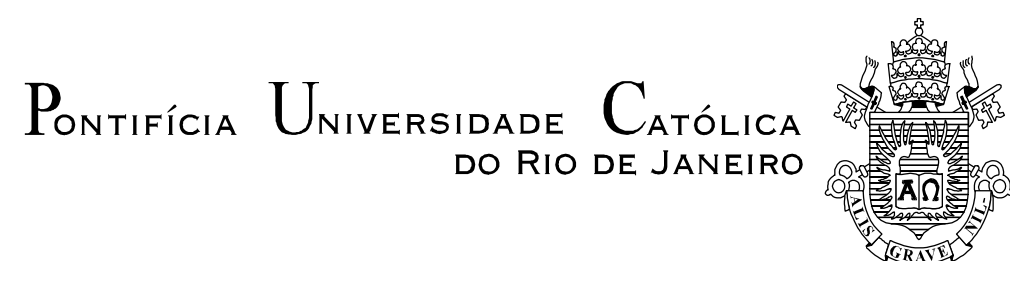

Jean Santarelli Monteiro de Castro

\title{
A Influência da Alteração Hidrotermal na Estabilidade de Escavações Subterrâneas no Rio de Janeiro
}

Dissertação apresentada como requisito parcial para obtenção do título de Mestre pelo Programa de Pós-Graduação em Engenharia Civil da PUCRio.

Orientador: Prof. Eurípedes do Amaral Vargas Junior Co-orientador: Prof. Rubem Porto Junior 


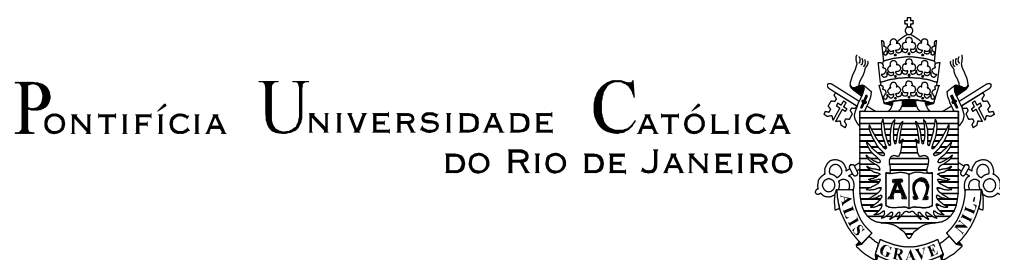

Jean Santarelli Monteiro de Castro

\title{
A Influência da Alteração Hidrotermal na Estabilidade de Escavações Subterrâneas no Rio de Janeiro
}

\begin{abstract}
Dissertação apresentada como requisito parcial para obtenção do título de Mestre pelo Programa de PósGraduação em Engenharia Civil da PUC-Rio. Aprovada pela Comissão Examinadora abaixo assinada.
\end{abstract}

Prof. Eurípedes do Amaral Vargas Junior Orientador Departamento de Engenharia Civil - PUC-Rio

Prof. Rubem Porto Junior Departamento de Geociências - UFRRJ

Prof. Cláudio Palmeiro do Amaral Departamento de Geociências - UERJ

Dr. Franklin dos Santos Antunes Consultor Independente

Prof. Márcio da Silveira Carvalho Coordenador Setorial do Centro Técnico Científico - PUC-Rio 
Todos os direitos reservados. É proibida a reprodução total ou parcial do trabalho sem autorização da universidade, do autor e do orientador.

\section{Jean Santarelli Monteiro de Castro}

Graduou-se em geologia pela Universidade Federal Rural do Rio de Janeiro em 2013. Ingressou no mestrado de engenharia civil em 2014, na Pontifícia Universidade Católica do Rio de Janeiro, desenvolvendo Dissertação na linha de pesquisa de Geotecnia em Escavações Subterrâneas.

Ficha Catalográfica

Castro, Jean Santarelli Monteiro de

A influência da alteração hidrotermal na estabilidade de escavações subterrâneas no Rio de Janeiro / Jean Santarelli Monteiro de Castro ; orientador: Eurípedes do Amaral Vargas Júnior. ; co-orientador: Rubem Porto Júnior. - 2016.

105 f. : il. color. ; $30 \mathrm{~cm}$

Dissertação (mestrado) - Pontifícia Universidade Católica do Rio de Janeiro, Departamento de Engenharia Civil, 2016.

Inclui bibliografia

1. Engenharia civil - Teses. 2. Alteração hidrotermal. 3. Geologia de engenharia. 4. Maciços rochosos. 5. Petrografia. 6. Mineralogia.. I. Vargas Júnior, Eurípedes do Amaral. II. Porto Júnior, Rubem. III. Pontifícia Universidade Católica do Rio de Janeiro. Departamento de Engenharia Civil. IV. Título. 
"Na vida temos a ânsia de dar e fazer pelo outro sempre alguma coisa, porém na maioria das vezes "o outro" não quer que você faça, ele quer apenas que você seja". (Padre Fábio de Melo)

Dedico este trabalho primeiramente a Deus que tem me sustentado em todos os momentos, dando sempre paz ao meu coração e a minha família que sempre me apoiou nessa nova etapa da minha vida. 


\section{Agradecimentos}

Agradeço primeiramente a Deus porque até aqui tem me ajudado, pois tem me dado forças e paz ao meu coração para que eu possa trilhar o meu caminho.

Aos meus pais, Eurico e Doris, por todo o amor, dedicação e carinho que sempre tiveram comigo em todos os momentos, me apoiando e me fazendo acreditar que com humildade é possível chegar nos meus objetivos. Custumo dizer que vocês fazem parte do meu currículo e são o melhor livro que eu já li na minha vida e tem sido muito especial conviver com vocês todo esse tempo.

A minha irmã Juliana Santarelli pela amizade, confiança e todo amor para comigo.

A minha namorada Gabriela por todo companheirismo, amor e pela capacidade que só ela tem de mesmo longe se fazer presente dentro de mim.

Ao Professor Eurípedes Vargas, orientador do presente trabalho, as interessantes sugestões, os ensinamentos, o permanente estímulo e disponibilidade demostrado durante a realização desse trabalho. Obrigado pela compreensão e amizade, emprestando seus ouvidos, me aconselhando e principalmente me tratado com humildade, seriedade e respeito.

Ao Professor Rubem Porto, por todo o ensinamento nesses sete anos de amizade, isso extrapola a relação dentro do ambiente acadêmico. Muito obrigado pelos conselhos e sugestões, foram uma contribuição valiosa para a minha formação pessoal e profissional. A sua ética e humanitarismo, assim como o seu grande profissionalismo e competência, fazem de ti uma referência importante na minha vida pessoal e acadêmica.

Ao grande Professor Franklin Antunes, os preciosos ensinamentos sobre mineralogia, os quais, muito facilitaram o reconhecimento das transformações estudadas no presente trabalho. Além dos vários conselhos e conversas que muito me enriqueceram para ser um ser humano cada vez melhor.

Ao professor Claudio Amaral pelos ensinamentos, conselhos e sugestões durante o trabalho. 
A todos os amigos que fiz durante o curso pela amizade que construímos, em particular aqueles que estavam sempre ao meu lado, Andreia, Rodrigo Tamoyo, Natália, Gabrielle, Renato (carechimba), Rodrigo, Ian, Malko, Mauro, por todos os momentos que passamos esses anos, de muito estudo, companheirismo e também muitas brincadeiras e risadas. Uma grande famíliade fato.

À Professora Michelle que participou indiretamente desse trabalho, ajudando no meu crescimento acadêmico, me aconselhando e motivando nos momentos mais difíceis. Obrigado pela amizade, paciência e compreensão oferecida por todo esse tempo.

Ao pessoal do Laboratório de Geotecnia da PUC, em especial, Edson e Victor que me ajudaram em todos os momentos.

À Thais por se mostrar uma pessoa de extrema gentileza e companheirismo.

Aos meus amigos de longa data, Xuenki e Bruno, pela ajuda durante a realização desse trabalho.

Ao CETEM por ter realizado as análises de DRX, em especial ao Professor Luiz Carlos Bertolino, por quem tenho muito respeito e admiração.

À Capes e à PUC-Rio, pelos auxílios concedidos, sem os quais este trabalho não poderia ter sido realizado. 


\section{Resumo}

Castro, Jean Santarelli Monteiro; Junior, Eurípedes Vargas do Amaral; Porto Jr. Rubem. A Influência da Alteração Hidrotermal na Estabilidade de Escavações Subterrâneas no Rio de Janeiro. Rio de janeiro, 2016. 105 p. Dissertação de Mestrado - Departamento de Engenharia Civil, Pontifícia Universidade Católica do Rio de Janeiro.

Com base nos frequentes relatos de problemas associados à alteração hidrotermal, durante a escavação de túneis na cidade do Rio de Janeiro, com destaque para a ação de argilas expansivas e/ou minerais secundários, decidiu-se estudar profundamente os aspectos petrográficos-genéticos básicos das rochas que afloram num túnel da região de Jacarepaguá e avaliar até que ponto a influência da alteração hidrotermal favorece as modificações de resistência dos maciços que afloram naquela região. Para isso foram realizadas investigações detalhadas das amostras coletadas dentro do túnel e no "bota fora". No laboratório as amostras foram submetidas à análise petrográfica na lupa e microscópio, análises por difração de raios-x e ensaio de resistência. Foram estabelecidas correlações entre as transformações químicas mineralógicas ocorridas nos litotipos que afloram no túnel com a sua resistência. Com os resultados obtidos foi constatada a importância da alteração hidrotermal nos projetos de túneis e desta forma pode-se concluir que pequenas abordagens geológicas podem minimizar vários problemas de engenharia.

\section{Palavras-chave}

Alteração hidrotermal; Geologia de engenharia; Maciços rochosos; Petrografia; mineralogia. 
Castro, Jean Santarelli Monteiro; Junior, Eurípedes Vargas do Amaral; Porto Jr., Rubem (Advisor). The Influence of Hydrothermal Alteration in the Stability Underground Excavation in Rio de Janeiro. Rio de Janeiro, 2015. 105 p. MSc. Dissertation - Departamento de Engenharia Civil, Pontifícia Universidade Católica do Rio de Janeiro.

Based on the frequent problems of reports associated with hydrothermal alteration, during the excavation of tunnels in the city of Rio de Janeiro, especially the action of swelling clays and/or secondary mineral, it decided to deeply study the basic aspects petrographic-genetic this rocks appear in the tunnel of Jacarepaguá region and assess to what extent the influence of hydrothermal alteration favors changes massive resistance that appear in the region. For that were conducted detailed investigations of the samples collected in the tunnel and the "slag heap". In the laboratory, the samples were subjected to petrographic analysis on the magnifying glass and microscope, analysis by diffraction of x-rays and strength test. Correlations were established between the mineralogical chemical transformations in rock types that appear in the tunnel with their resistance. With the results, it was found the importance of hydrothermal alteration in the projects of tunnels and thus it can be concluded that small geological approaches can minimize various engineering problems.

\section{Keywords}

Hydrothermal alteration; Engineering geology; Rock mass; Petrography; Mineralogy. 


\section{Sumário}

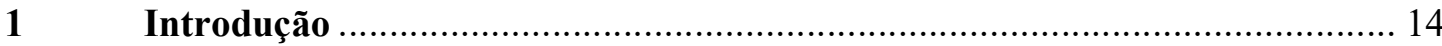

1.1 Justificativa do estudo ........................................................................... 15

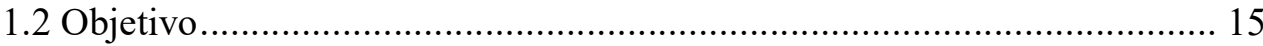

1.3 Organização da dissertação .................................................................... 15

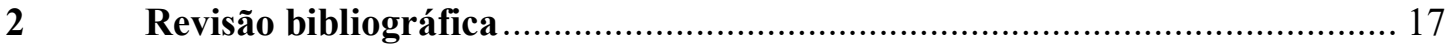

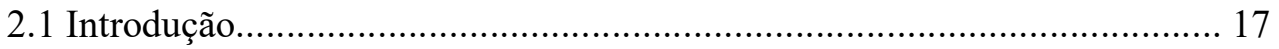

2.2 A alteração hidrotermal e os demais processos de alteração nos

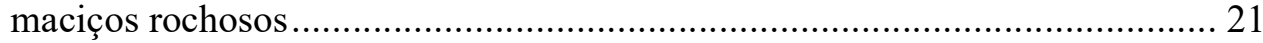

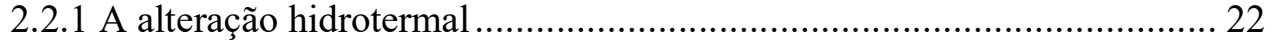

2.2.2 Formação dos argilominerais por alteração hidrotermal....................... 28

2.2.3 Efeitos da alteração de interesse geotecnico ...................................... 35

3 Materiais e métodos utilizados na avaliação da alteração hidrotermal ......... 39

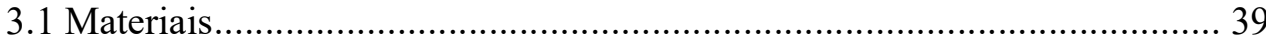

3.1.1 Contexto geológico local.............................................................. 41

3.2 Caracterização dos materiais ............................................................... 44

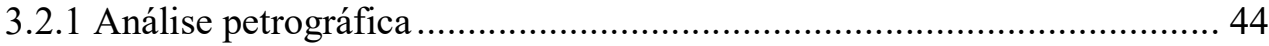

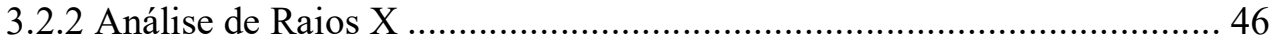

3.2.3 Resistência à compressão puntiforme ................................................. 48

4

Resultados

4.1 Caracterização da alteração hidrotermal nas rochas do túnel da

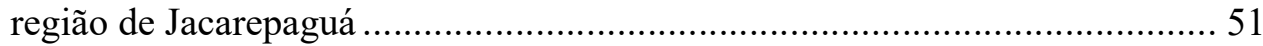

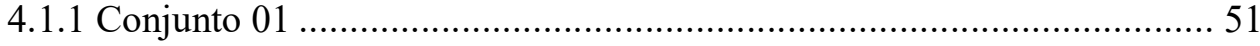

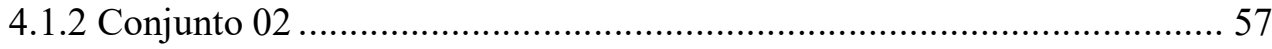

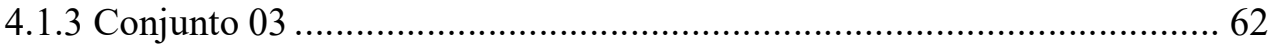

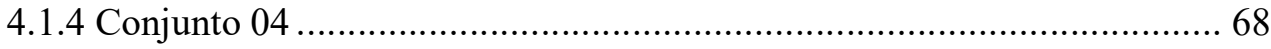

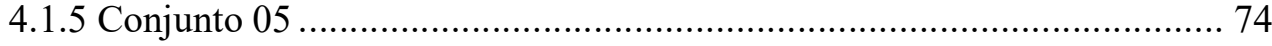

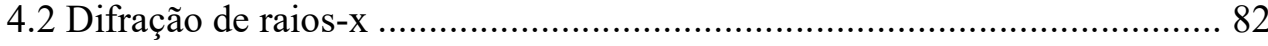

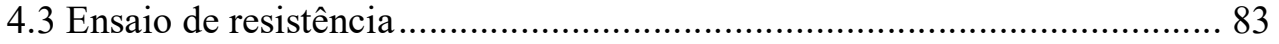




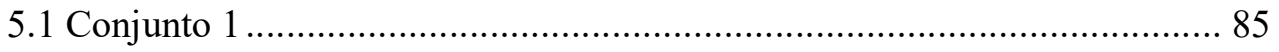

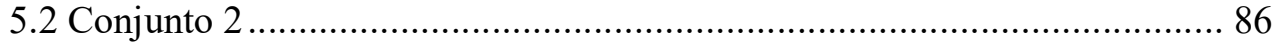

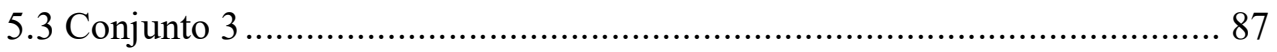

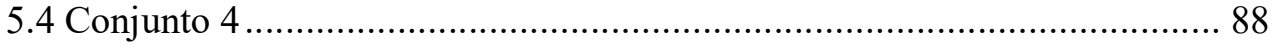

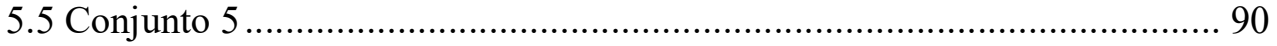

5.6 Resistência à compressão Puntiforme...................................................... 91

5.7 Considerações a respeito das classificações geomecânicas ........................ 94

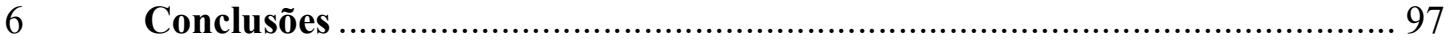

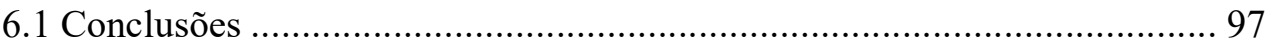

6.2 Sugestões para trabalhaos futuros........................................................ 99

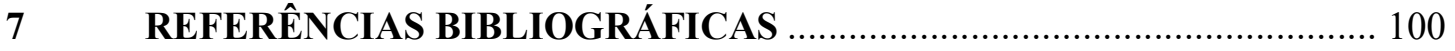




\section{ÍNDICE DE FIGURAS}

FIGURA 1- (A) Evolução de um sistema hidrotermal como função da temperatura e das

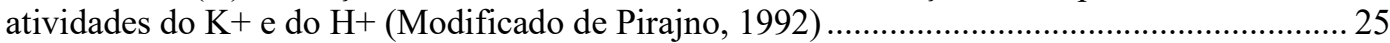

FIGURA 2 - Estrutura de base da caulinita (Grim, 1968) ....................................................... 30

FIGURA 3 - Esquema estrutural da muscovita. A ilita se assemelha a essa estrutura

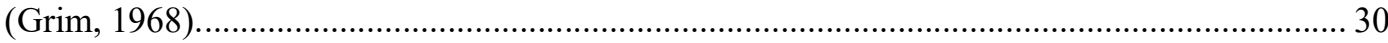

FIGURA 4 - Estrutura dos argilominerais do grupo da esmectita e da clorita (Mitchell,

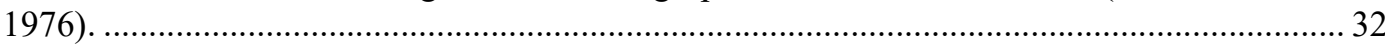

FIGURA 5 - Aspecto do gnaisse kinzigitico no campo. Vale resaltar a grande quantidade

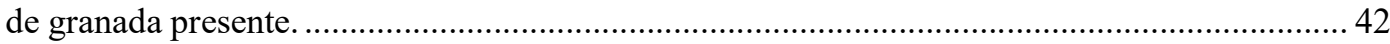

FIGURA 6 - Aspecto da paragenese do biotita gnaisse (esquerda) e porfiroblásto de microclina em biotita gnaisse (direita).

FIGURA 7 - Aspecto dos equipamentos de análise microscópica de rochas do laboratório de geotecnia da PUC-Rio.

FIGURA 8 - Equipamento resistência a compressão puntiforme (Point Load Test)

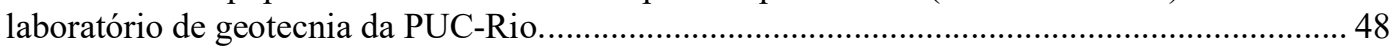

FIGURA 9 - Forma da amostra e tipo de compressão puntual indicado. (ISRM, 1985)............ 49

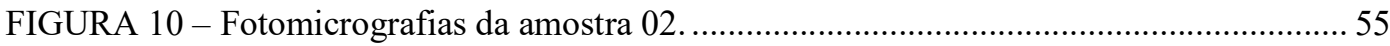

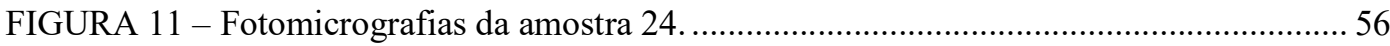

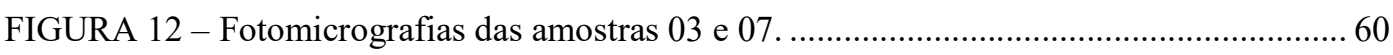

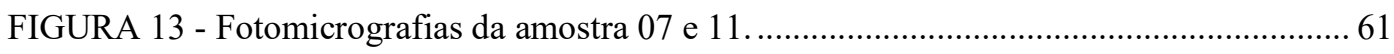

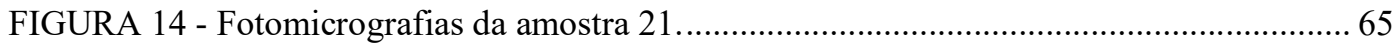

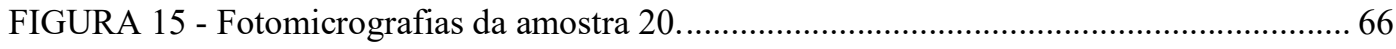

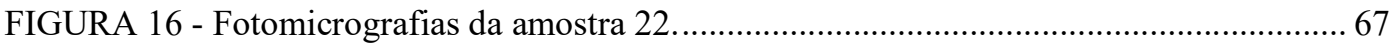

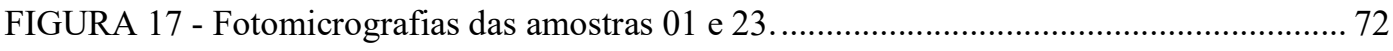

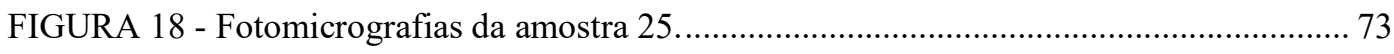

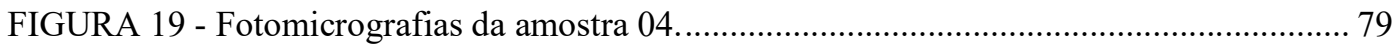

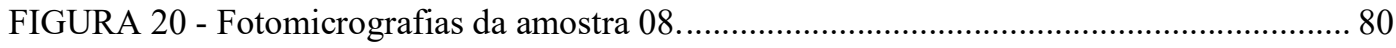

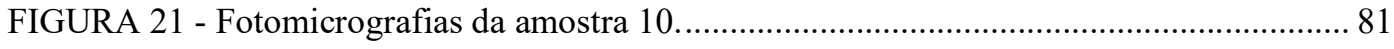

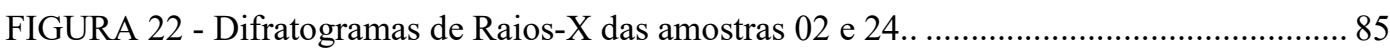

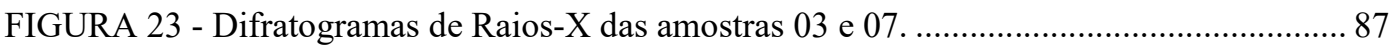

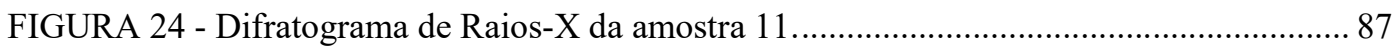

FIGURA 25 - Difratogramas de Raios-X das amostras 20 e 21 ................................................. 88

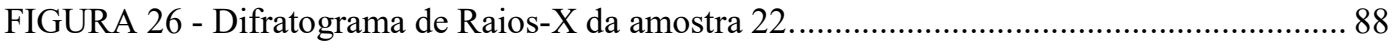

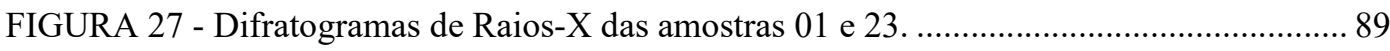

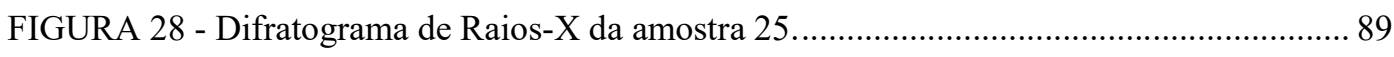

FIGURA 29 - Difratogramas de Raios-X das amostras 04, 08 e 10, ......................................... 91 


\section{ÍNDICE DE TABELAS}

TABELA 1 - Principais reações envolvendo minerais primários e seus prováveis produtos na alteração hidrotermal.

TABELA 2 - Reações secundárias de alteração de minerais primários magmáticos (Wernick, 2004).

TABELA 3 - Principais constituíntes dos argilominerais (modificado de Velde, 1992).

TABELA 4 - Formação de minerais secundários por alteração hidrotermal (Misas, 2010)

TABELA 5 - Métodos para avaliação da alteração e alterabilidade de rochas. Maia (2001).

TABELA 6 - Graus de alteração de rocha (IPT, 1984, apud Serra Junior e Ojima, 1988)

TABELA 7 - Identificação das amostras coletadas no campo, bem como sua alteração a vista desarmada de acordo com a classificação do IPT, 1984.

TABELA 8 - Procedimento para identificação de argilominerais por difratometria de raio X (modificada de Frazão, 2012).

TABELA 9 - Valor geral de C em função do De (ASTM, 1995) ................................. 50

TABELA 10 - Composição mineralógica das amostras analisadas............................... 82

TABELA 11 - Classificação proposta pela ISRM, que em função do grau de

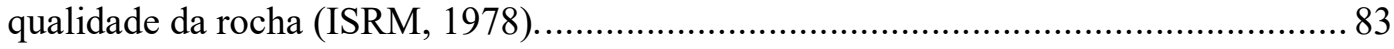

TABELA 12 - Resultados da resistência a compressão puntiforme ............................ 84

TABELA 13 - Resistência das amostras do CONJUNTO 01 .................................. 91

TABELA 14- Resistência das amostras do CONJUNTO 02 ........................................ 92

TABELA 15- Resistência das amostras do CONJUNTO 03 .......................................93

TABELA 16- Resistência das amostras do CONJUNTO 04 …....................................93

TABELA 17- Resistência das amostras do CONJUNTO 05 ........................................ 94 


\section{SÍMBOLOS E ABREVIAÇÕES}

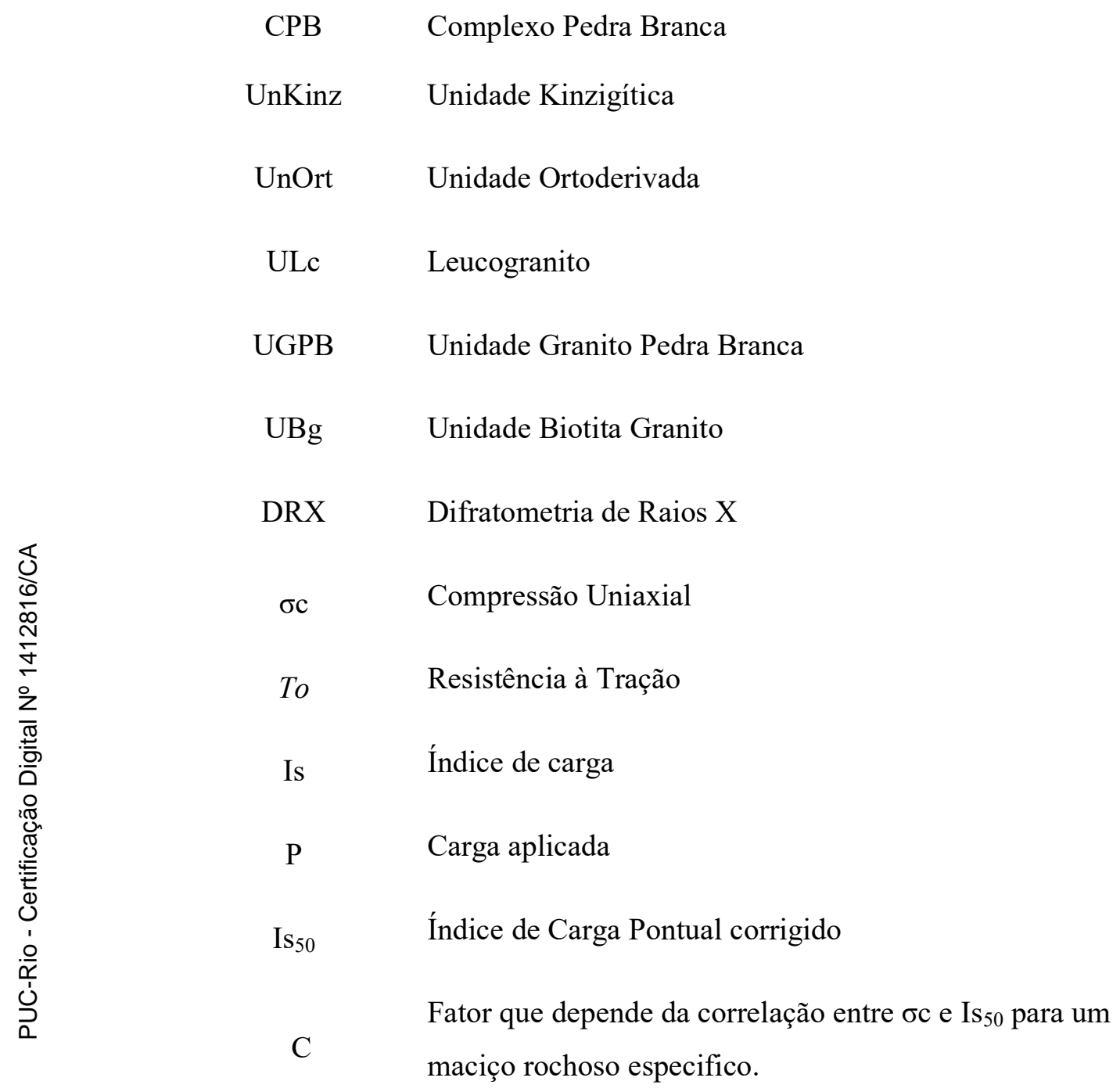




\section{INTRODUÇÃO}

Normalmente, o assunto principal nas investigações preliminares de projetos de túneis é a previsão de sua estabilidade. As obras subterrâneas se deparam com vários fatores que precisam ser muito bem avaliados e que exigem um entendimento entre as partes técnica e econômica. A geologia possui um papel importante nesse balanceamento entre custos e eficiência das soluções, bem como na definição da segurança contra acidentes e gestão do risco. A geologia tanto ajuda na definição dos melhores processos de escavação quanto nos melhores tratamentos dos maciços rochosos escavados.

Parte dos acidentes registrados em túneis no Estado do Rio de Janeiro está relacionada à presença de feições associadas a alterações hidrotermais das rochas e a consequente redução da qualidade/resistência do maciço rochoso escavado. Essas alterações hidrotermais correspondem a transformações mineralógicas condicionadas por petrotramas estruturais, e impõem, também, uma alterabilidade elevada das rochas, tornando-as mais susceptíveis à ação dos agentes intempéricos.

Apesar destes condicionantes geológicos na instabilidade das obras subterrâneas, em especial, túneis, já terem sido destacados por vários autores no passado (Geo-Rio, 2001; Silva, 2001) e acidentes registrados em diversos túneis do Rio de Janeiro (Guandú, Rebouças, Santa Bárbara, Joá, São Conrado, Grota Funda) tendo sido relacionados à presença de feições associadas à alteração hidrotermal e à consequente redução da qualidade/resistência do maciço rochoso escavado, a verdade é que o seu reconhecimento como importante, e o seu devido diagnóstico, continuam desconsiderados ou esquecidos nas fases de projeto. Parte da explicação para este "esquecimento" está no fato de que a alteração hidrotermal é, em geral, de difícil identificação a vista desarmada e, em função disto, exige a realização de análises de lâminas petrográfica e de ensaios de difração de raios-x no material fino. 
A cidade do Rio de Janeiro é neste momento um importante foco de transformações do meio urbano, em função da realização em 2014 da Copa do Mundo e neste ano das Olímpiadas (Agosto, 2016). Como resultado, diversas obras foram realizadas na cidade pela Prefeitura do Rio de Janeiro, com o intuito de melhorar o movimento no espaço urbano, como corte de taludes para estradas, abertura de túneis, etc.

Este trabalho pretende contribuir para que se confira à alteração hidrotermal e à alterabilidade a importância devida no desenvolvimento dos projetos de túneis, e para dirimir a incompreensão quanto ao custo, à extensão, à aplicação e ao benefício que a execução de uma correta investigação geológica pode trazer à segurança dos túneis ao longo de sua operação.

\subsection{JUSTIFICATIVA DO ESTUDO}

Com base nos frequentes relatos de problemas associados à alteração hidrotermal, durante a escavação de túneis na cidade do Rio de Janeiro, com destaque para a ação de argilas expansivas e/ou minerais secundários, decidiu-se estudar profundamente os aspectos petrográficos-genéticos básicos das rochas que afloram num túnel da região de Jacarepaguá.

\subsection{OBJETIVO}

O objetivo principal desta pesquisa é avaliar até que ponto a influência da alteração hidrotermal favorece as modificações de resistência dos diferentes litotipos que afloram num túnel da regiãode Jacarepaguá, zona oeste da cidade do Rio de Janeiro, criando padrões de separação de transformações químico mineralógicas no campo de eventos geológicos (alterações hidrotermais e retrometamorfismo) a outros de interesse mais especifico no campo geotécnico (intemperismo).

\subsection{ORGANIZAÇÃO DA DISSERTAÇÃO}

Este trabalho está dividido em cinco capítulos, de acordo com as etapas de pesquisa realizadas, iniciando com este capítulo introdutório (Capítulo 1), seguido do Capítulo 2, onde é apresentada uma revisão da literatura existente, 
compreendendo os tópicos referentes aos principais assuntos abordados nesta pesquisa.

No Capítulo 3 é descrito detalhadamente o programa experimental como também é apresentada uma descrição dos materiais utilizados, dos equipamentos e dos métodos de ensaios.

O Capítulo 4 consiste na apresentação e análise dos resultados, considerando aspectos referentes à petrografia, caracterização mineralógica e resistência dos materiais estudados.

No Capítulo 5 são apresentadas as discussões a respeito dos resultados obtidos no capítulo anterior.

No Capítulo 6 são apresentadas as principais conclusões que representam a síntese do conhecimento adquirido durante a realização deste trabalho, onde se encontram também as sugestões para futuros trabalhos. 
2

\section{REVISÃO BIBLIOGRÁFICA}

\subsection{INTRODUÇÃO}

O conhecimento das características petrográficas das rochas, bem como de suas propriedades físicas e físico-mecânicas, permitem uma melhor previsão de seu comportamento frente às obras civis e de meio ambiente, gerando prognósticos e desenvolvimento de medidas preventivas ou reparadoras de riscos geológicos, e aumentando sua segurança.

O estudo das transformações mineralógicas das rochas e a consequente perda de resistência mecânica dos maciços rochosos são temas que integram a linha de pesquisa do Professor Rubem Porto Junior desde 2000, mas outros autores nacionais também se dedicaram ao tema, e têm merecido atenção de diversos pesquisadores devido a muitos insucessos e a repetição de casos de comportamento indesejado. Esses insucessos poderiam ter sido evitados se tivesse havido um maior conhecimento das propriedades destes materiais e um melhor entendimento de seu comportamento ante as diferentes solicitações em serviço. A alteração das rochas tem grande influência na segurança, economia e estética da obra que elas fazem parte.

Ao referir-se à alteração das rochas, Minette (1982) afirma que uma rocha pode passar a solo em poucos dias, meses ou anos, principalmente quando o clima proporciona uma taxa de alteração elevada e o estado de alteração é acentuado ou as tensões a que a rocha está submetida ou atacada são elevadas.

Na cidade do Rio de Janeiro, segundo Carvalho (1998), a grande maioria das obras subterrâneas em maciços rochosos foram implantadas em domínio dos litotipos leptinito e gnaisse facoidal, sendo que algumas delas apresentaram intercalações de biotita-gnaisse e kinzigito (túneis Sá Freire Alvim, Santa Barbara, Rebouças, Dois Irmãos e Covanca). Quando da presença dessas outras litologias (biotita gnaisse, principalmente), normalmente ocorreram condicionantes geológico-geotécnicas de destaque nas escavações, como rocha alterada, falhas, 
diques e zonas fraturadas ocasionando, inclusive, sérios acidentes (túneis Santa Bárbara e Rebouças).

Carvalho (1998) relata que sérios acidentes nos túneis Santa Bárbara e Rebouças, estiveram associados à presença de rocha alterada, falhas, diques e zonas de fraturadas. No túnel de adução do sistema Guandú, diques, zonas pegmatíticas, milonitos e argilas expansivas ocasionaram quedas de blocos, fissuramentos e deformações no revestimento.

Barroso (1993) relata que o biotita gnaisse, litotipo no qual se desenvolvem os solos residuais mais espessos, possui elevada alterabilidade, correlacionando-a a processos de alteração hidrotermal e ao intemperismo.

Silva (2011) e Geo-Rio (2001) estudaram as rochas dos emboques do Túnel da Grota Funda, devido grande parte do maciço rochoso a ser escavado não apresentar características geológicas homogêneas, detalhando claramente os mecanismos de alteração hidrotermal que influenciaram na resistência das rochas do túnel.

Campos (2007) associou o problema de instabilidade do túnel do Joá à alteração hidrotermal e ao grau de fraturamento em trechos extensos do túnel, condicionantes estas que foram desconsideradas na classificação geomecânica do maciço feito à época da sua construção.

Brito (1981) e Sertã (1986) evidenciaram nas análises petrográficas dos perfis de alteração no Campus da PUC - Rio, processos de alteração hidrotermal associados à transformação de k-feldspato em caulinita (caulinitização), já que não havia material com sinais de oxidação que evidenciariam atividade intempérica intensa. Polivanov (1998) constatou na biotita gnaisse do Maciço da Tijuca à presença de caulinita formada por produtos de alteração hidrotermal, favorecendo a sua alteração de forma acelerada.

Silva (1997) descreveu testemunhos de sondagens em perfis de intemperismo do leptinito em Laranjeiras e Botafogo, nos quais identificou transformações químicas e mineralógicas de origem hidrotermal, que favoreciam a alteração intempérica mais rápida da rocha.

Oliveira (2006) caracterizando um perfil de alteração de rocha granitognáissica da cidade de Curitiba no Paraná, constatou na petrografia que a esmectita encontrada no solo alterado não é um mineral neoformado, mas sim um mineral de origem hidrotermal que já se encontrava na rocha matriz, justificando a 
importância de uma boa análise petrográfica nas obras de engenharia geotécnica a fim de prever o comportamento geotécnico dos materias resultantes dos diferentes graus de alteração a que eles sofreram.

Em nível internacional, Farran e Thénoz (1965), descrevem um caso onde rochas graníticas muito resistentes e compactas, perderam suas qualidades em poucos meses, desagregando-se e formando solos sem coesão.

Thuro (2003) descreve as zonas de intemperismo e de alteração hidrotermal do maciço rochosos granítico no qual foi construído o Túnel Konigshainer Berge, na Alemanha. O autor conclui que a alteração hidrotermal induz ao aumento da porosidade do maciço rochoso, e que este, exposto, rapidamente se altera.

Hasegawa (2006) apresenta o projeto do Túnel da via expressa da região de Shikoku no Japão, com destaque para os resultados da difração de Raios-X que apontaram a presença de esmectita de origem hidrotermal. Segundo o autor, as argilas expansivas causaram deslocamentos durante a escavação do túnel, razão pela qual é importante o monitoramento antes e durante a sua construção.

Frolova (2014) chama à atenção para os efeitos da alteração hidrotermal nas propriedades físicas e mecânicas de rochas na ilha do arco de KurilKamchatka, próximo a Rússia. O seu estudo mostrou que os fluídos de alta temperatura causam a consolidação e fortalecimento da rocha, diminuindo sua porosidade e permeabilidade. Essa tendência é observada independente da composição química dos fluídos. Em contrapartida, fluídos de baixas temperaturas, em geral mais próximos da superfície causam diminuição da densidade, resistência, módulo de elasticidade e formação de porosidade secundária. Portanto, zonas com intensa atividade hidrotermal podem causar diversos efeitos na integridade de fundações e instabilidade de maciços rochosos.

Tu (2005) mostra o comportamento induzido por alteração hidrotermal em granito e a sua implicação na escavação do túnel da usina de Heimifeng na China. Essa rocha reconhecida como meio ideal na maioria das vezes para a escavação subterrânea mostrou, no entanto, que existem expansões induzidas pela alteração do granito causando hidratação de minerais e consequentemente a desintegração dos blocos. O estudo mostrou que a alteração hidrotermal do granito deu origem a minerais secundários como montmorilonita, clorita, caulinita, evidenciando que são as principais causas para o comportamento de 
expansão do granito. Tu (2005) diz que as características da rocha alterada devido à expansão são um grande desafio para os suportes e revestimentos durante as fases de construção e operação, devendo esses estar em vigor imediatamente após a escavação.

Zhang (2010) apresenta as propriedades de rochas alteradas e suas implicações na construção de túneis integrantes da Ferrovia Yunnan-Tibet, em Sanjiang, sudoeste da China. Segundo o autor, nas cinco zonas de rochas alteradas há montmorilonita formada por ação hidrotermal, com alto potencial de expansão e elevada atividade físico-química, razão pela qual devem ser adotadas medidas preventivas durante a sua construção.

Nishimoto (2009) investigou os efeitos da alteração hidrotermal nas transformações mineralógicas numa profundidade de 200 metros nas fraturas de um granito. A observação ao microscópio, DRX, FRX, entre outras, mostrou a ocorrência deilita, quartzo e pirita e que um halo em volta da fratura pode ser subdividido numa zona fílica adjacente à fratura, rodeada por uma zona propilítica em que filossilicatos estão presentes. Os processos que resultam nessas mudanças ocorreram em três fases sucessivas: 1) dissolução parcial de plagioclásio com cloritização parcial da biotita; 2) dissolução da biotita e precipitação de $\mathrm{Fe}$ filossilicato nos poros da dissolução; 3) dissolução do K-feldspato e $\mathrm{Fe}$ filossilicatos e precipitação da ilita associado com o desenvolvimento de micro fissuras. Essas alterações hidrotermais do granito procedem principalmente por um processo de dissolução-precipitação resultante da infiltração de fluído hidrotermal ao longo de microfissuras. Essa infiltração provoca localmente elevada mobilidade de Al e aumenta a proporção de líquido no halo de alteração. Estes resultados contribuem para a compreensão de como rocha granítica se altera em campos orogênicos tais como o arco da ilha japonesa.

Junior (1983) catalogou diversos acidentes causados por materiais expansivos em obras civis, procurando mostrar as maneiras pelas quais estes materiais expansivos podem ocorrer e se comportar. Farjallat (1969) citado por Junior (1983) relata que um basalto compacto, homogêneo e são, utilizado no enrocamento do aterro da Ponte do Rio Sucuriú, em poucos meses começou a apresentar numerosas fissuras, atribuindo grande fragilidade no material. Segundo esse autor, basaltos compactos e sãos podem se desagregar rapidamente quando expostos às variações das águas superficiais e também mostra que a desagregação 
está relacionada com o conteúdo de minerais secundários expansivos devido a alterações deutéricas ou hidrotermais.

Junior (1983) cita a ocorrência de minerais expansivos preenchendo zonas de falhas e fissuras causando escorregamentos no túnel da usina hidrelétrica de Hemsil I, no sul da Noruega. Partes do túnel que foram consideradas perigosas foramrevestidos com concreto projetado, o que funcionou por um período de oito meses, aonde o material veio a escorregar devido a filmes de clorita entre duas falhas as quais continham montmorilonita. Ao mecanismo de escorregamento foi dada a seguinte interpretação: o concreto projetado não havia impedido o acesso da água e não foi capaz de resistir à pressão de expansão do material montmorilonítico e combinada com a baixa coesão das fissuras cloríticas, levou ao escorregamento propriamente dito.

Devido a isto, está claramente demonstrado que alguns fatores responsáveis pelo enfraquecimento do maciço rochoso com o passar do tempo estão intimamente ligados à perda das propriedades geomecânicas intrínsecas dos maciços rochosos causadas por transformações químicas e mineralógicas. Esse fenômeno, muitas vezes difícil de compreender e, mais ainda de quantificar, explica que muitas estruturas rochosas dão, por períodos longos, uma falsa sensação de estabilidade mecânica, ao passo que na verdade, elas continuam a evoluir, por vezes quase imperceptível a sofrer uma ruptura súbita, geralmente difícil de prever.

\subsection{A ALTERAÇÃO HIDROTERMAL E OS DEMAIS PROCESSOS DE ALTERAÇÃO NOS MACIÇOS ROCHOSOS}

De acordo com Aires-Barros (1971) a alteração de uma rocha é a sua desagregação e decomposição por agentes físicos e químicos naturais, que transformam essa rocha em outro produto natural, agora em equilíbrio físicoquímico com o meio ambiente.

Os processos de alteração atuam em duas fases distintas, isoladamente ou em conjunto, dependendo das condições ambientais. Uma fase é a desagregação, que se reflete na perda de coesão da rocha e na progressiva individualização dos seus constituintes minerais sem que haja alteração química significativa de seus componentes. A outra é a decomposição, fase a qual se reflete na modificação 
progressiva da natureza dos minerais, por meio de remoção iônica, onde o resultado é a formação dos minerais secundários ou residuais (Saunders \& Fookes, 1970). Apesar de esses mecanismos serem analisados separadamente, esta separação é puramente superficial, pois eles ocorrem de maneira simultânea durante a alteração. O que se destaca é a intensidade que um se impõe em relação ao outro, de acordo com o ambiente geológico e climático.

A taxa que uma rocha vai se alterar vai depender de vários fatores mineralógicos, dentre os quais podemos citar sua estrutura e composição, superfície específica, sistema de cristalização, irregularidade na superfície cristalina, acessibilidade aos agentes e lixiviação. Esses fatores associados à temperatura, pressão, presença de voláteis, tipo de ligação entre os elementos químicos, dentre outros, são características essenciais da massa em cristalização.

Minette (1982) diz que a continuidade de um mecanismo de alteração é definida pela possibilidade do agente de alteração circular no contato com os minerais, provocando desequilíbrio pela possibilidade de remoção dos produtos de alteração. Sendo a disposição espacial dos átomos uma característica essencial da facilidade ou dificuldade desses agentes terem acesso aos minerais.

\subsubsection{A ALTERAÇÃO HIDROTERMAL}

O termo hidrotermal está intimamente associado à atividade de fluidos relativamente quentes originados por atividades magmáticas (ou mesmo metamórfica) ou por atividade ígnea residual. Assim, processos hidrotermais associam-se à atividade ígnea e envolvem águas aquecidas ou superaquecidas.

A alteração hidrotermal define-se então como a substituição química dos minerais originais de uma rocha por um conjunto de novos minerais mais estáveis sob as condições hidrotermais de temperatura, pressão e, principalmente, composição do fluído (Rose \& Burt, 1979; Reed, 1997). A sua compreensão é importante porque fornece subsídios para a definição dos atributos químicos e físicos responsáveis pela formação de depósitos minerais, comportamento eruptivo nos sistemas vulcânicos, propriedades geofísicas do manto e, principalmente no que diz respeito esse trabalho, na influência de maneira significativa no fraturamento, alteração e deformação das rochas. 
A alteração hidrotermal de uma rocha e mineral é fruto das transformações químicas, mineralógicas e texturais resultantes da interação de fluídos tipicamente dominados por água quente com a rocha a temperaturas que vão desde $<100^{\circ} \mathrm{C} \mathrm{a}>500^{\circ} \mathrm{C}$, sob determinadas condições físico-químicas, com rochas nas quais percola homogeneamente ou em fissuras (Pirajno, 1992). O estágio da atividade hidrotermal está associado ao resfriamento magmático ou ao incremento no grau metamórfico, quando são possíveis de ser acumulada fase residual de voláteis. Os limites exatos referentes a estes estágios são variáveis e, dependendo do autor, podem ser definidos por assembleias minerais presentes na rocha, por estimativa de temperatura, pela composição dos fluídos atuantes dentre outros. Portanto a alteração mineralógica documenta a história pós-formação da rocha e as informações que tem implicâncias práticas, como informações sobre o reservatório e características do fluído e a evolução do sistema de energia geotérmica.

Há ainda aquilo que se define como metamorfismo hidrotermal. Este tipo é causado pela percolação de fluidos ou de soluções de gases aquecidos por entre fraturas e/ou foliações e que causam mudanças de fases mineralógicas presentes. Atividades no campo do hidrotermalismo associadas a padrões estruturais (zonas de cisalhamento, por exemplo) são bastante frequentes.

O único fator de separação entre os processos de caráter hidrotermal e processos retrometamórficos, é o fato de que, quando a substituição se dá de forma total, esta se associa ao retrometamorfismo, enquanto que quando a substituição é parcial, tanto processos hidrotermais quanto o próprio retrometamorfismo podem ser os causadores.

Depósitos hidrotermais são agregados minerais formados por precipitação e que ocorrem, principalmente, relacionados a processos de substituição mineral em planos de fraturas, brechas, planos de falhas, espaços intergranulares. Esta atividade envolve processos que ocorrem entre 50 e 600 graus Celsius, sendo mais bem caracterizados no intervalo entre 50 e 400 graus Celsius em pressões variando entre 1 e 3 kbars.

Como resultado de sua ação, a presença de rochas em algum nível alterado é comum. Sua ocorrência e estudo são quase desconhecidos no ambiente da Geotecnia. Alguns eventos magmáticos, metamórficos de alta temperatura, penetração de água subterrânea em áreas profundas e zonas de cisalhamento são 
capazes de gerar uma variação termal nas rochas que estão envolvidas nesses processos.

Os fluídos hidrotermais agem nas rochas através de seus condutos, brechas, fraturas primárias ou secundárias, foliações, sendo esta ação dependente da permeabilidade do maciço. Alguns elementos dissolvidos e/ou minerais produzidos depositados sofrem ação de líquidos e soluções de alta temperatura gerando o processo de alteração hidrotermal, o qual age diretamente na rocha e forma argilominerais através da deposição de soluções quentes.

As diferentes interações dos fluidos hidrotermais com as rochas sob diferentes condições de temperatura e razão $\mathrm{aK}^{+} / \mathrm{aH}^{+}$(atividade de potássio e hidrogênio no sistema), como mostrado na figura 1 têm importante papel nos processos de alteração hidrotermal e são capazes de gerar alguns dos principais processos, como:
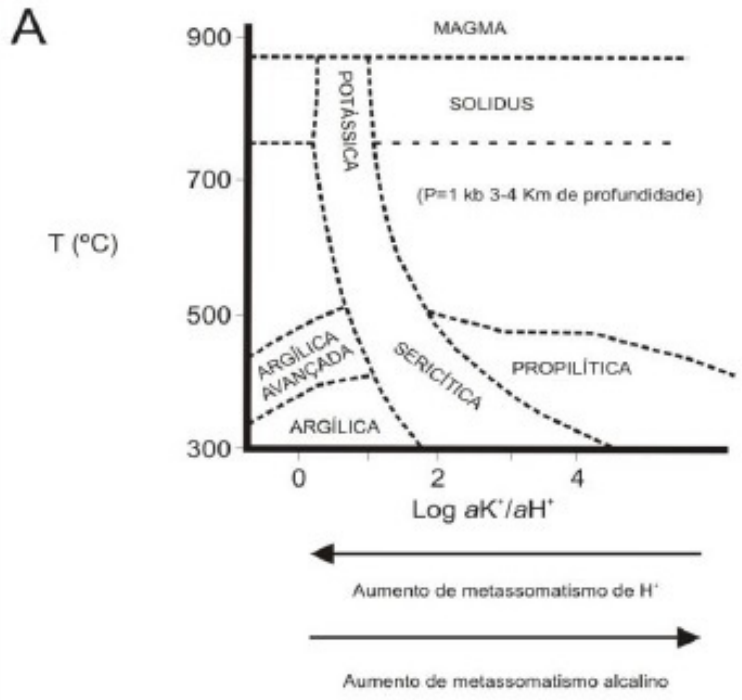
B

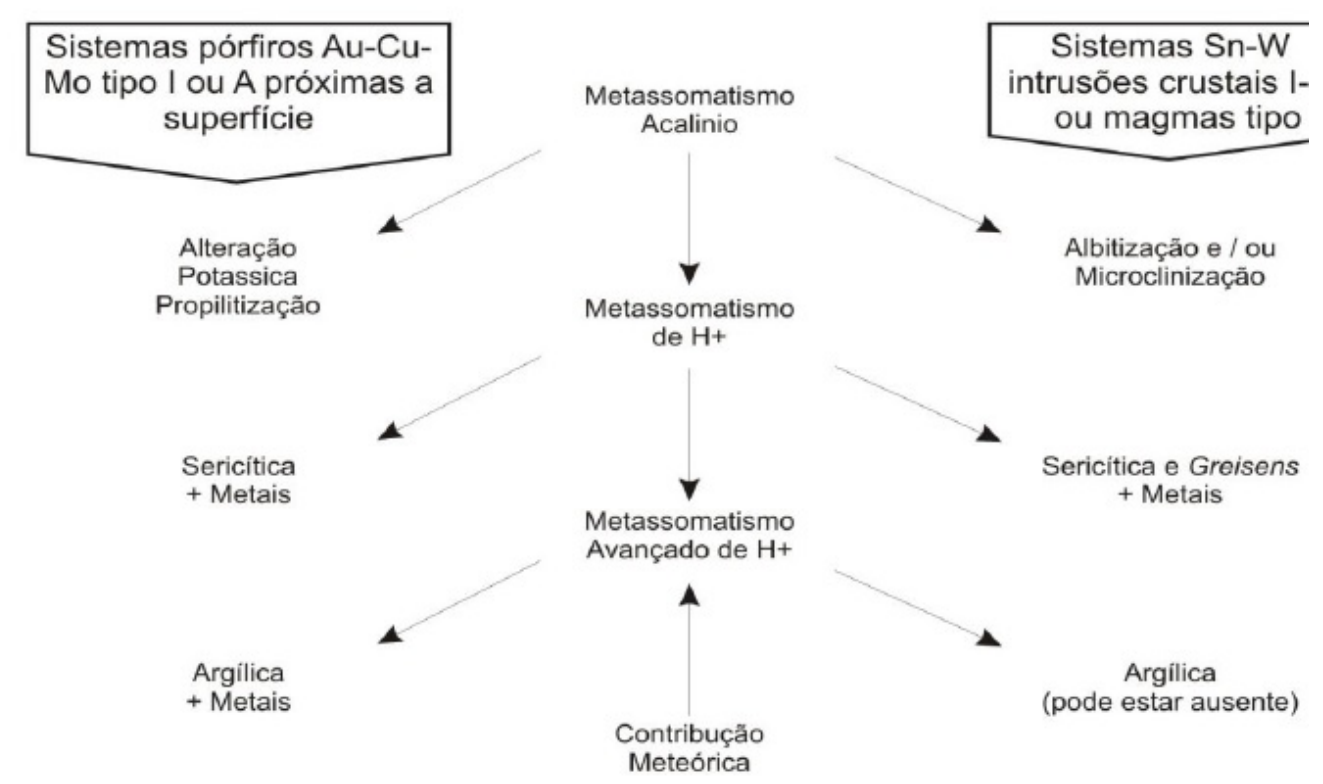

FIGURA 1 - (A) Evolução de um sistema hidrotermal como função da temperatura e das atividades do $\mathrm{K}^{+}$e do $\mathrm{H}^{+}$(Modificado de Pirajno, 1992). À medida que o sistema evolui para temperaturas e pressões mais baixas há um progressivo aumento de $\mathrm{H}^{+}$e uma evolução progressiva do tipo de alteração alcalina para argílica. (B) $\mathrm{O}$ metassomatismo alcalino libera $\mathrm{H}^{+}$havendo, como consequência, uma diminuição na razão álcalis/ $\mathrm{H}^{+}$, com subsequente desestabilização dos feldspatos e micas e crescimento de novas fases minerais (zonas de alteração greisen e sericitica). Um intenso metassomatismo de $\mathrm{H}^{+}$devese à entrada de água meteórica no sistema, provocando mais oxidação e produção de $\mathrm{H}^{+}$. A este processo podem ser associadas às zonas de alteração argílica e lixiviação ácida. (Pirajno, 1992).

Cloritização: É a alteração de qualquer mineral para clorita, em geral biotita e anfibólio. Clorita é um filosilicato muito hidratado, e normalmente substitui os minerais máficos menos hidratados a temperaturas baixas quando a água esta disponível. Piroxênios, hornblendas e biotitas são frequentemente observadas em seção delgada em vários estágios de alteração para clorita. Como em outras alterações deutéricas, a hidratação atua principalmente da margem para o centro do mineral, de modo que a clorita comumente substitui as bordas ou planos preferenciais dos minerais alterados. 
Exemplo:

Biotita $+(\mathrm{CI}, \mathrm{F})+\mathrm{H}_{2} \mathrm{O}+\mathrm{CO}_{2 \rightarrow \text { clorita }}+\mathrm{K}(\mathrm{CO} 2, \mathrm{CI}, \mathrm{F})$

Sericitização: É o processo pelos quais minerais félsicos ricos em $\mathrm{K}^{+}(\mathrm{K}$ feldspato e Plagioclásio alcalino) são hidratados para produzir sericita. Estágios iniciais podem ser reconhecidos por uma aparência empoeirada fina de feldspatos. Em estágios mais avançados da alteração, os feldspatos aparecem salpicados com micas finas com cor de interferência amarelada e com cristais grossos e alta birrefringência. O processo de Sericitização de plagioclásios envolve a liberação de $\mathrm{K}^{+}$, tal íon pode ser fruto de cloritização de biotita nas proximidades do plagioclásio.

Saussuritização: É o processo onde os plagioclásios mais

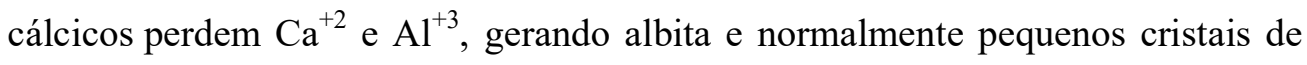
epidoto, sericita, carbonato e, às vezes também clorita, gerando aspecto poiquilítico, recebendo o nome de saussurita. Os plagioclásios são susceptíveis à ação de soluções hidrotermais, sendo as variedades mais sódicas mais resistentes, porém menos que a microclina. A alteração também pode gerar escapolita, prehnita, zeólitas, alofano, montmorillonita e caulinita. Equação que explica esse processo:

Plagioclásio $+(\mathrm{CI}, \mathrm{F})+\mathrm{H}_{2} \mathrm{O}+\mathrm{CO}_{2} \rightarrow$ sericita $+\mathrm{SiO}_{2}+\mathrm{Ca}\left(\mathrm{CO}_{2}, \mathrm{CI}, \mathrm{F}\right)$

Muscovitização: É a formação de muscovita e/ ou sericita em minerais máficos (biotita) e félsicos (K-feldspato);

$$
\begin{aligned}
& 3 \mathrm{~K} \mathrm{AI} \mathrm{Si}_{3} 0_{8}+2 \mathrm{HCI} \rightarrow \mathrm{K} \mathrm{Al}_{2} \mathrm{Si}_{3} \mathrm{O}_{10}(\mathrm{OH})_{8}+6 \mathrm{SiO}_{2}+2 \mathrm{KCI} \text { ou } \\
& \text { Microclina (3K AI Si } \left.{ }_{3} 0_{8}\right)+\mathrm{OH} \rightarrow \text { muscovita }+ \text { quartzo. }
\end{aligned}
$$

Caulinização: Processo de decomposição de determinados silicatos aluminosos, em que ocorre a dissolução parcial de minerais, como os feldspatos, produzindo-se sílica dissolvida e minerais de argila, como a caulinita. Em geral ocorre em minerais félsicos (plagioclásio e k-feldspato). A equação química que traduz esta reação é: 
$2 \mathrm{KAlSi}_{3} \mathrm{O}_{8}+\mathrm{H}_{2} \mathrm{CO}_{3}+\mathrm{H}_{2} \mathrm{O}_{\rightarrow} \mathrm{K}_{2} \mathrm{CO}_{3}+\mathrm{Al}_{2} \mathrm{Si}_{2} \mathrm{O}_{5}(\mathrm{OH})_{4}+4 \mathrm{SiO}_{2}$ na qual $2 \mathrm{KAlSi}_{3} \mathrm{O}_{8}$ é o feldspato e $\mathrm{Al}_{2} \mathrm{Si}_{2} \mathrm{O}_{5}(\mathrm{OH})_{4}$ a caulinita.

Epidotização: Atuante em minerais máficos (biotita e anfibólio) e félsicos (plagioclásio);

Oxidação: Atuante em minerais opacos (óxidos e sulfetos) e ocorrendo como resíduo em alguns dos processos anteriores;

$$
4 \mathrm{FeSiO}_{3} \text { (piroxênio) }+\mathrm{O}_{2} \rightarrow 2 \mathrm{~F}_{2} \mathrm{O}_{3} \text { (hematita) }+4 \mathrm{SiO}_{2} \text { (dissolvido) }
$$

Carbonatização: Atuante em minerais félsicos (K-feldspato e plagioclásio).

$$
2 \mathrm{KAlSi}_{3} \mathrm{O}_{8}+2 \mathrm{H}_{2} \mathrm{CO}_{3}+\mathrm{H}_{2} \mathrm{O} \rightarrow \mathrm{Al}_{2} \mathrm{Si}_{2} \mathrm{O}_{5}(\mathrm{OH})_{4}+4 \mathrm{SiO}_{2}+2 \mathrm{~K} 1+2 \mathrm{HCO}_{3}
$$

(íon bicarbonato)

Serpentinização: Atuante em minerais máficos (olivinas e piroxênios).

Olivina + Piroxênio $+\mathrm{H}_{2} \mathrm{O}+\mathrm{O}_{2 \rightarrow}$ Serpentina + Brucita + Magnetita

TABELA 1- Principais reações envolvendo minerais primários e seus prováveis produtos na alteração hidrotermal.

\begin{tabular}{|l|l|}
\hline Reação de minerais primários & \multicolumn{1}{c|}{ Alteração hidrotermal } \\
\hline Olivina & Serpentina + Óxidos de Ferro (magnetita) \\
\hline Augita e Diopsídio & $\begin{array}{l}\text { Clorita + Serpentina + Talco + Oxidos de } \\
\text { Ferro }\end{array}$ \\
\hline Hornblenda & Clorita + Carbonato \\
\hline K-feldspato & Sericita + Caulinita + Muscovita \\
\hline Plagioclásio & Epidoto + Calcita + Sericita + Caulinita \\
\hline Biotita & Muscovita + Clorita \\
\hline
\end{tabular}

A intensidade da alteração hidrotermal que afeta uma rocha pode ser definida como fraca, moderada e forte (intensa) e são relacionadas com o estado de substituição das fases da rocha e do estado de destruição das texturas.

As alterações hidrotermais ou deutéricas ocorrem em grau variável na maioria das rochas intrusivas, em algumas rochas vulcânicas e em espessos 
depósitos de cinzas vulcânicas (a desvitrificação de vidros vulcânicos pode ser considerada também como um tipo de alteração hidrotermal). Em muitos casos essa alteração confere à rocha um aspecto lixiviado, desbotado, e pode frequentemente, levar o obscurecimento quase total da mineralogia e textura primaria (Wernick, 2004).

Como se pode perceber, alguns processos de formação dos minerais secundários recebem nomes específicos tais como carbonatização, cloritização, caulinitização, serpentinização e etc. $\mathrm{Na}$ tabela 2 constam algumas reações secundárias de alteração de minerais magmáticos primários.

TABELA 2 - Reações secundárias de alteração de minerais primários magmáticos (Wernick, 2004).

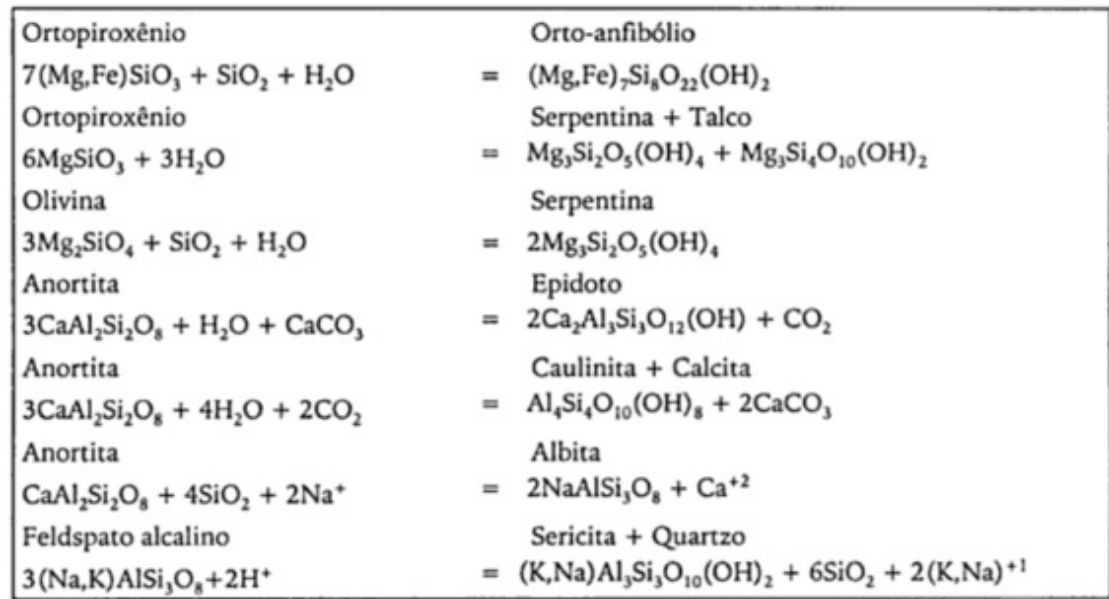

\subsubsection{FORMAÇÃO DOS ARGILOMINERAIS POR ALTERAÇÃO HIDROTERMAL}

Os argilominerais são constituídos basicamente por silício, alumínio, ferro, magnésio e íons de $\mathrm{O}^{2}$ e $\mathrm{OH}^{-}$. A estrutura dos argilominerais é formada por grupos tetraédricos e octaédricos de íons de $\mathrm{O}^{2}$ e $\mathrm{OH}^{-}$ao redor de cátions de silício, alumínio, ferro ou magnésio. Esses grupos estão ligados entre si formando uma folha contínua, tetraédrica ou octaédrica (Velde, 1992). A tabela 3 apresenta os principais constituintes dos diferentes argilominerais. 
TABELA 3 - Principais constituintes dos argilominerais (modificado de Velde, 1992).

\begin{tabular}{c|c|c}
\hline \hline \multicolumn{2}{c|}{ Argilomineral } & Constituintes principais \\
\hline \hline \multirow{2}{*}{$\begin{array}{c}\text { Expansivos } \\
\text { (esmectita) }\end{array}$} & montmorilonita & $\mathrm{Al}\left(\mathrm{Mg}, \mathrm{Fe}^{2+}\right.$ reduzido $)$ \\
\cline { 2 - 3 } & nontronita & $\mathrm{Fe}^{3+}$ \\
\hline \multirow{2}{*}{$\begin{array}{c}\text { Não expansivos } \\
\text { (caulinita) }\end{array}$} & ilita & $\mathrm{k}, \mathrm{Al}(\mathrm{Fe}, \mathrm{Mg}$ reduzido $)$ \\
\cline { 2 - 3 } & clorita & $\mathrm{Mg}, \mathrm{Fe}, \mathrm{Al}$ \\
\cline { 2 - 3 } & haloisita & $\mathrm{Al}$ \\
\cline { 2 - 3 } & caulinita & $\mathrm{Al}$ \\
\hline
\end{tabular}

O grupo da caulinita compreende dois subgrupos (caulinita e serpentina). A caulinita (figura 2) é constituída por uma camada de tetraedro e uma de octaedro, formando um mineral 1:1. Em geral não existem substituições por cátions dentro da estrutura cristalina, a qual é eletricamente neutra. Este fato é preponderante no comportamento mecânico da caulinita, formando um mineral bastante estável, sem a capacidade de adsorção, sendo o argilomineral mais comum nos solos residuais maduros. Devido a esses fatores a caulinita não caracteriza o solo como problemático, principalmente quanto à característica de plasticidade e expansão. (Carvalho, 1997).

As camadas estruturais ligam-se entre si, por pontes de hidrogênio entre átomos $\mathrm{O}^{2}$ e por grupos de $\mathrm{OH}^{-}$de planos atômicos justapostos. Sua fórmula é representada por $(\mathrm{OH})_{8} \mathrm{Si}_{4} \mathrm{Al}_{4} \mathrm{O}_{10}$. 


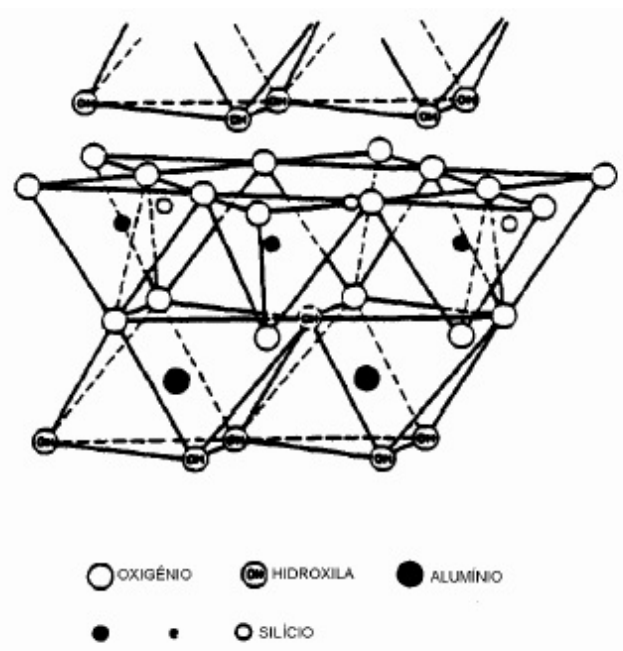

FIGURA 2 - Estrutura de base da caulinita (Grim, 1968)

Os argilominerais do grupo das micas são os minerais mais frequentes nas argilas. As ilitas fazem parte desse grupo e sua estrutura assemelha-se a elas, das quais derivam em regra, por divisão física e alteração química. As ilitas são constituídas por uma folha octaédrica intercalada a duas folhas tetraédricas, sendo as camadas estruturais ligadas por cátions monovalentes, normalmente $\mathrm{K}^{+}$, possuindo espaçamento basal de 1,0 nm (Grim 1968).

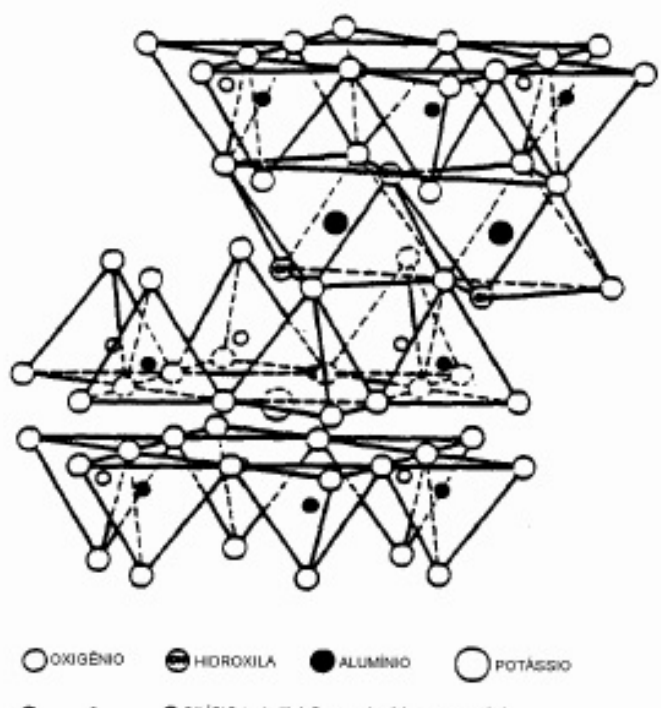

FIGURA 3- Esquema estrutural da muscovita. A ilita se assemelha a essa estrutura (Grim, 1968). 
O que difere a ilita da montmorilonita, é que a ilita não apresenta expansibilidade intracristalina, devido à forte ligação iônica gerada pelos íons $\mathrm{K}^{+}$ entre as camadas estruturais. Entretanto, pelo menor número de íons potássio, carga negativa estar na folha octaédrica e devido à maior distância dos íons $\mathrm{K}^{+}$ originando forças eletrostáticas mais fracas, a montmorilonita $\mathrm{K}^{+}$apresenta expansibilidade intracristalina. (Grim, 1968).

A ilita possui maior carga elétrica negativa por unidade de superfície do que a montmorilonita e a carga negativa da ilita está localizada na folha tetraédrica, ou seja, mais próxima dos cátions intercalares. Em contrapartida, na montmorilonita a carga está mais concentrada na folha octaédrica. Assim, as forças estruturais intercaladas na ilita são mais fortes, e a água e outros líquidos polares não conseguem penetrar em suas camadas.

Os argilominerais do grupo das esmectitas são filossilicatos constituídos pela justaposição de uma camada octaédrica de $\mathrm{Al}^{3+}$ entre duas camadas tetraédricas de $\mathrm{Si}^{4+}$. Estas três camadas formam uma unidade básica tripla, classificada como 2:1. Nos argilominerais esmectíticos a fórmula estrutural pode ser considerada como intermediária entre as fórmulas estruturais do talco e da pirofilita. O grau de hidratação entre as camadas 2:1 provoca o inchamento macroscópico e depende do cátion e da composição química da esmectita, segundo Grim (1968). À distância interplanar basal das esmectitas em estado normal de hidratação é de $14 \AA$. Estes minerais apresentam grande capacidade de trocas catiônicas e de absorção de água. Isso faz das esmectitas minerais com grande potencial de expansão. O principal mineral do grupo é a montmorilonita $\left(\mathrm{AL}_{2} \mathrm{O}_{3} \cdot 4 \mathrm{SiO}_{2} \cdot \mathrm{H}_{2} \mathrm{O}\right)$, onde o magnésio substitui o alumínio e íons monovalentes no espaço interlamelar e balanceiam as cargas. As montmorilonitas ocorrem em veios hidrotermais como produto da alteração de feldspatos sódico-cálcicos e de biotitas.

O grupo das cloritas possue estrutura básica semelhante aos minerais do grupo da esmectita. No entanto, a substituição de cátions de cargas diferentes ocorre principalmente nas camadas tetraédricas, onde em cada quatro tetraedros, três são ocupados por $\mathrm{Si}^{4+}$ e uma por $\mathrm{Al}^{3+}$. Esta característica também é típica dos argilominerais do grupo das micas. Nos espaços interlamelares, as cloritas, ao invés de cátions livres, apresentam uma camada de brucita $\left(\mathrm{Mg}[\mathrm{OH}]_{2}\right)$. A constituição da brucita é semelhante à de uma camada octaédrica. Assim, o grupo 
da clorita é classificado como 2:1:1. Os principais cátions octaédricos são $\mathrm{Mg}^{2+} \mathrm{e}$ $\mathrm{Fe}^{2+}$. A carga residual, resultante da substituição de $\mathrm{Si}^{4+}$ por $\mathrm{Al}^{3+}$, é balanceada pela substituição de $\mathrm{Mg}^{2+}$ por $\mathrm{Al}^{3+}$ na camada de brucita. A estrutura destes minerais é mais estável que a das esmectitas. As cloritas possuem baixa capacidade de troca catiônica e de absorção de água, sendo assim, minerais pouco expansíveis.

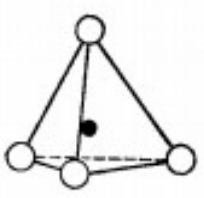

Tetraedro de silicio $\left(\mathrm{SiO}_{4}\right)$

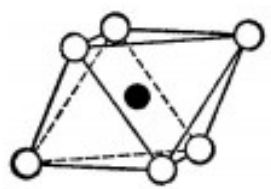

Octaedro de aluminio $\left[\mathrm{Al}_{2}(\mathrm{OH})_{6}\right]$ ou magnésio $\left[\mathrm{Mg}(\mathrm{OH})_{6}\right]$

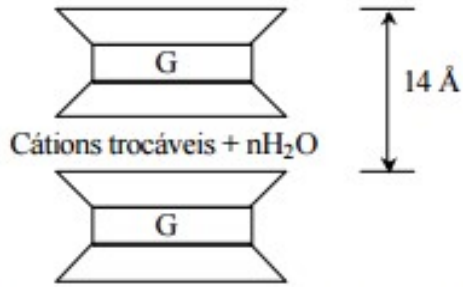

Estrutura dos argilominerais do grupo das esmectitas

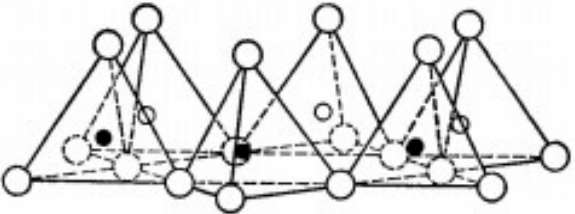

Folha em arranjo hexagonal de tetraedro de silício

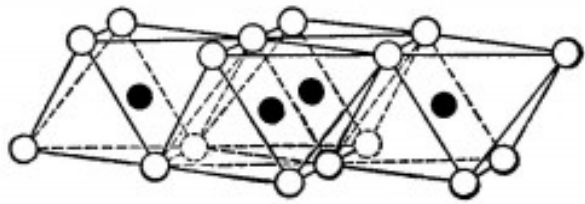

Folha em arranjo hexagonal de octaedros de alumínio ou magnésio

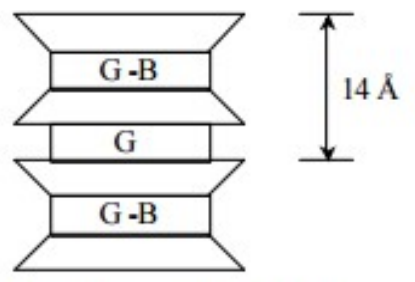

Estrutura dos argilominerais do grupo das cloritas

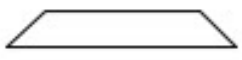

Representação esquemátic folhas de tetraedro de sili

\begin{tabular}{|c|}
\hline $\mathrm{G}$ \\
\hline $\mathrm{e}$ \\
\hline $\mathrm{B}$ \\
\hline
\end{tabular}

Representações esquemáti follas de octaédro de alumi (gibsita), e de magnésio B (b

Legenda:

$O$ ou $\hat{O}$... átome oxigênio para os tetrac oxidrilas para os octaédros O ou ... átomos de silíci -... átomos de alı magnésio, etc.

FIGURA 4 - Estrutura dos argilominerais do grupo da esmectita e da clorita (Mitchell, 1976).

O grupo da Vermiculita $(2: 1)$ possui expansão mais limitada que a montmorilonita na presença de água e outras moléculas polares. A vermiculita apresenta uma capacidade expansiva um pouco menor que a montmorilonita na presença de cátions bivalentes, sendo que para cátions monovalentes é variável, semelhante no caso do $\mathrm{Li}^{+}$, muito inferior para o $\mathrm{Na}^{+}$e inexistente para $\mathrm{o} \mathrm{K}$. $\mathrm{O}$ espaçamento basal é de $14 \mathrm{~nm}$, podendo variar de acordo com o cátion de troca e do estado de hidratação do cristal. A vermiculita pode resultar da alteração 
hidrotermal de biotita ou flogopita. Ocorre também em solos normalmente e interestratificados com clorita ou com mica do tipo ilita.

O grupo dos argilominerais interestratificados compreende modelos estruturais variados que são intermediários ou mistos dos grupos anteriores. Os que ocorrem com maior frequência são: montmorilonita-clorita, montmorilonitailita, clorita-vermiculita, ilita-vermiculita e vermiculita-clorita. Sendo a montmorilonita-vermiculita o que apresenta o maior potencial expansivo.

Os minerais pertencentes ao grupo dos silicatos, exceto o quartzo, podem ser transformados em argilominerais, conhecidos como minerais secundários. Os argilominerais também podem ser chamados de minerais neoformados ou de neoformação. Neste caso, são resultantes da precipitação ou combinação de substâncias resultantes do intemperismo de outros minerais.

A ação de gases (especialmente o vapor d'água) e soluções aquosas com temperatura superior à do ambiente, sobre os minerais primários das rochas, podem causar a sua transformação em argilominerais.

Os produtos de alteração hidrotermal são frequentemente encontrados associados com jorros quentes e geysers em vesículas nas rochas ígneas e em fraturas.

Segundo Grim (1968), se a alteração hidrotermal for intensa, como resultado de altas temperaturas e concentrações, longa e contínua, então todos os minerais originais devem ser afetados, e se há um considerável transporte dos elementos, os produtos de alteração poderão tender a serem indiferentes dos da rocha mãe, exceto em rochas carboníferas e quartizíferas. No caso de siltito, a tendência e a silicificação, mas a reação entre o magnésio e a sílica algumas vezes formam argilominerais ricos em magnésio, como é o caso das esmectitas do depósito Hector, Califórnia.

Se a alteração hidrotermal é relativamente ligeira, o caráter dos minerais primários determina os produtos de alteração. Em alterações muito ligeiras, os minerais ricos em magnésio como hornblenda e biotita tendem a mudar para clorita. Em processo de alteração ligeira e em presença de elementos alcalinos e alcalinos terrosos, exceto, o potássio, das micas, os minerais ferromagnesianos e os feldspatos plagioclásios vão provavelmente formar esmectita. A presença do potássio, dos feldspatos ou micas primárias favorece o desenvolvimento de micas 
secundárias, como é o caso de um riolito adjacente a um andesito, dando ilita como produto de alteração a qual mais tarde altera-se em esmectita.

Os argilominerais do grupo das Caulinitas podem-se formar de quaisquer constituintes se os elementos alcalinos e alcalinos terrosos forem removidos tão rapidamente quanto liberados da rocha mãe ou se o ambiente de formação for ácido e a temperatura moderada. Quando o cálcio está presente na formação dos argilominerais do grupo das caulinitas sua formação é tardia.

Kerr (1956, apud Grim, 1968), cita que a permeabilidade, a porosidade e a maneira com o fluído penetra são importantes no processo de alteração.

Tooker (1956, in Grim, 1968), enfatiza que as características da rocha hospedeira (encaixante) são de extrema importância na localização e no arranjo zonal de alteração.

Sales e Meyer (1948, apud Grim, 1968), Ross e Hendricks (1945, apudGrim, 1968), e outros tem mostrado que os argilominerais se alteram formando outros argilominerais se as condições hidrotermais variarem. Sob o ponto de vista geotécnico, o processo hidrotermal é relevante nas escavações em maciços rochosos na estabilidade de taludes e na utilização de rochas para agregados.

TABELA 4 - Formação de minerais secundários por alteração hidrotermal (Misas, 2010).

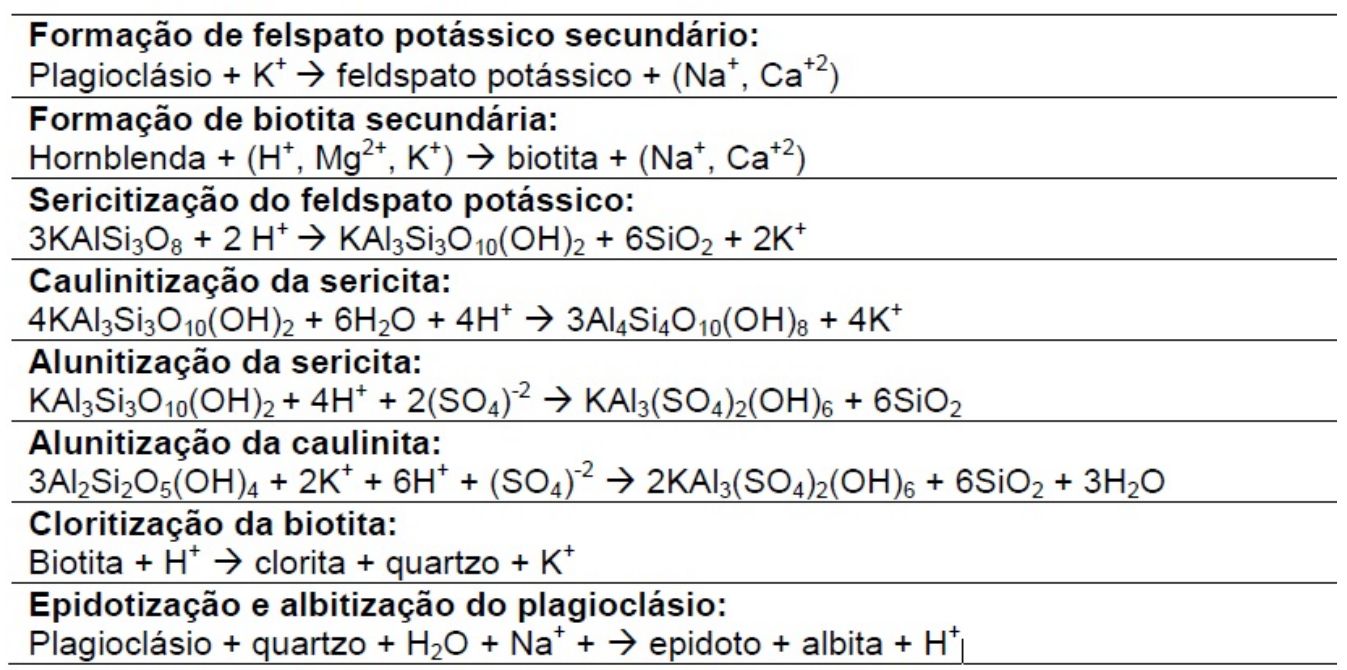




\subsubsection{EFEITOS DA ALTERAÇÃO DE INTERESSE GEOTECNICO}

Segundo Frazão (2012), na engenharia civil têm sido numerosos os problemas provocados pelas modificações das características iniciais das rochas por processos de alteração que podem levar a sua degradação, ou quando não, a consequências que afetam negativamente seu desempenho em serviço.

As características que traduzem a qualidade dos meios rochosos, do ponto de vista de seu aproveitamento em engenharia civil, associam-se, fundamentalmente à litologia, ao estado de alteração, à coerência e às descontinuidades.

Os principais problemas relatados na literatura do efeito da alteração nas rochas podem ser resumidos em:

a) Modificação da distribuição granulométrica dos minerais.

b) Aumento da porosidade e da capacidade de absorção de água.

c) Diminuição da resistência mecânica e aumento da deformabilidade.

d) Prejuízos da aderência e adesividade.

Frazão (2002) diz que o grau de alteração e alterabilidade podem ser avaliados por análises petrograficas e mineralógicas e por ensaios físicos e físicosmecânico. Existem diversos procedimentos sugeridos na literatura, por diversos pesquisadores para esse fim, segue abaixo alguns dos métodos:

a) Relação entre minerais sãos e minerais alterados, estado microfissural e minerais secundários

b) Balanço iônico

c) Evolução dos valores de massa especifica aparente, de porosidade aparente e da absorção de água

d) Variação da velocidade de propagação de ondas longitudinais

e) Variação granulométrica

f) Variação de resistência

g) Variação da granulometria conjugada à variação de resistência

Maia (2001) apresenta uma síntese de alguns índices de qualidade mais utilizados para avaliação de alterabilidade das rochas. Estes índices foram 
desenvolvidos para materiais rochosos por diversos pesquisadores com base em análises e ensaios de rotina laboratorial. $\mathrm{Na}$ tabela 5, pode-se perceber a importância da petrografia na análise de uma rocha alterada.

TABELA 5 - Métodos para avaliação da alteração e alterabilidade de rochas. Maia (2001).

\begin{tabular}{|c|c|c|}
\hline Referências & Métodos Sugeridos & $\begin{array}{l}\text { Critérios de avaliação do estado de } \\
\text { alteração ou dealterabilidade }\end{array}$ \\
\hline Rego e Santos (1938) & Porosidade aparente & $\begin{array}{l}\text { Para um mesmo tipo petrográfico: maior } \\
\text { porosidade, maior grau de alteração }\end{array}$ \\
\hline Pichler (1942) & $\begin{array}{l}\text { Petrografia e absorção } \\
\text { d'água }\end{array}$ & $\begin{array}{l}\text { Se a petrografia indicar minerais } \\
\text { alterados e a absorção for maior que } \\
0,5 \% \text {, a rocha deve ser rejeitada }\end{array}$ \\
\hline Day (1962) & $\begin{array}{l}\text { Petrografia } \quad \text { (basaltos), } \\
\text { ensaioDeval modificado e } \\
\text { granulometriados finos }\end{array}$ & $\begin{array}{l}\text { Teores de minerais alterados e variação } \\
\text { dagranulometria em relação à amostra } \\
\text { original }\end{array}$ \\
\hline Hamrol(1962) & $\begin{array}{l}\text { Absorção d'água e índice de } \\
\text { vazios }\end{array}$ & $\begin{array}{l}\text { Relação entre variação de absorção e do } \\
\text { índice de vazios, para o tempo } \\
\text { considerado }\end{array}$ \\
\hline Farran e Thénoz (1965) & $\begin{array}{l}\text { Permeabilidade ao ar e } \\
\text { superfície específica }\end{array}$ & $\begin{array}{l}\text { Para permeabilidade }>0,1 \mathrm{~m} / \mathrm{s} \text {, a } \\
\text { alterabilidade cresce com o aumento da } \\
\text { superfície específica }\end{array}$ \\
\hline Iliev (1966) & $\begin{array}{l}\text { Velocidade de propagação } \\
\text { de } \\
\text { Ultrassom }\end{array}$ & $\begin{array}{l}\text { Índice que relaciona velocidade de } \\
\text { ultrassom da rocha fresca e da rocha } \\
\text { alterada }\end{array}$ \\
\hline $\begin{array}{l}\text { Mendes et al. (1966) e } \\
\text { Barros (1969) }\end{array}$ & $\begin{array}{l}\text { Análise petrográfica } \\
\text { microscópica modal e } \\
\text { ensaios mecânicos }\end{array}$ & $\begin{array}{l}\text { Índice de alteração obtido pela relação } \\
\text { entre o teor de minerais sãos e a soma } \\
\text { dos teores de minerais alterados e de } \\
\text { vazios relacionado com o módulo de } \\
\text { deformação ou tensão de ruptura na } \\
\text { compressão }\end{array}$ \\
\hline $\begin{array}{c}\text { Talobre em } 1967 \\
\text { (citado em Yoshida, } \\
\text { 1972) }\end{array}$ & $\begin{array}{l}\text { Sanidade de amostras em pó } \\
\text { eem corpos de prova ao } \\
\text { HsSO4 }\end{array}$ & $\begin{array}{l}\text { Perdas em massa não devem ultrapassar } \\
18 \% \text { para amostra em pó e } 100 \mathrm{mg} \text { para } \\
\text { os corpos de prova }\end{array}$ \\
\hline $\begin{array}{l}\text { Schneider e Rocha } \\
\text { (1968) }\end{array}$ & petrográfica & $\begin{array}{l}\text { Teores em minerais secundários e em } \\
\text { argilominerais, expansivos e não- } \\
\text { expansivos, permitem avaliar estadode } \\
\text { alteração e indicar a necessidade ou não } \\
\text { de ensaios adicionais para material em } \\
\text { rodovias }\end{array}$ \\
\hline $\begin{array}{l}\text { Krauskopf (citado em } \\
\text { Loughnan, 1969) }\end{array}$ & Análise química & $\begin{array}{l}\text { Índice que relaciona os teores em } \\
\text { óxidos alcalino e alcalinos terrosos e a } \\
\text { soma destes com os de } \mathrm{Si}, \mathrm{Al} \text { e } \mathrm{Fe}\end{array}$ \\
\hline Struillou (1969) & $\begin{array}{l}\text { Imersão de fragmentos de } \\
\text { rocha de } 10-20 \mathrm{~mm} \text { em } \\
\mathrm{H} 2 \mathrm{O} 2 / 110 \text { vol. }\end{array}$ & $\begin{array}{l}\text { Comparação da porcentagem de } \\
\text { material passante na malha de abertura } \\
8 \mathrm{~mm} \text { com aquela apresentada por } \\
\text { material de desempenho conhecido }\end{array}$ \\
\hline HRB (1970) & $\begin{array}{lr}\text { Ensaio de abrasão } \\
\text { codificadoconjugado } \\
\text { compactação }\end{array}$ & $\begin{array}{l}\text { Comparação entre granulometria, } \\
\text { limites de Atterberg e equivalente de } \\
\text { areia para material ensaiado e o material } \\
\text { original }\end{array}$ \\
\hline Farjallat (1971) & $\begin{array}{l}\text { Ensaio de alteração por } \\
\text { lixiviação em extrator } \\
\text { Soxhlet associado a ensaio } \\
\text { de abrasão Los Angeles }\end{array}$ & $\begin{array}{l}\text { Índice de alterabilidade definido pela relação entre } \\
\text { porcentagem de material desagregado no ensaio } \\
\text { de alteração, com a porcentagem de perdas por } \\
\text { abrasão. }\end{array}$ \\
\hline
\end{tabular}




\begin{tabular}{|c|l|l|}
\hline Rocha (1971) & $\begin{array}{l}\text { Lixiviação contínua em } \\
\text { extrator Soxhlet em amostras } \\
\text { moídas }\end{array}$ & $\begin{array}{l}\text { Perdas de massa para tempos } \\
\text { restabelecidos de alteração no } \\
\text { laboratório }\end{array}$ \\
\hline $\begin{array}{c}\text { Scott (citado em } \\
\text { Farjallat 1971) }\end{array}$ & $\begin{array}{l}\text { Análise petrográfica } \\
\text { (basaltos) }\end{array}$ & $\begin{array}{l}\text { Teor em minerais secundários } \\
\text { superiores a 20\% sugere que a rocha } \\
\text { não deve ser especifica para uso na } \\
\text { construção civil }\end{array}$ \\
\hline Yoshida (1972) & $\begin{array}{l}\text { Ensaio de impacto Treton } \\
\text { associado a diferentes } \\
\text { ensaios de alteração no no } \\
\text { laboratório }\end{array}$ & $\begin{array}{l}\text { Indices de alteração obtidos pela } \\
\text { comparação entre os resultados dos } \\
\text { ensaios de impacto da rocha alterada e } \\
\text { da sã }\end{array}$ \\
\hline $\begin{array}{l}\text { Wylde (1980,1982) } \\
\text { determinação de um fator } \\
\text { petrográfico a nível }\end{array}$ & $\begin{array}{l}\text { Avaliação da desagregação de basaltos } \\
\text { usados como base de pavimentos } \\
\text { através da observação das ligações entre } \\
\text { partículas }\end{array}$ \\
\hline $\begin{array}{l}\text { Ladeira e Minette } \\
\text { (1984) }\end{array}$ & $\begin{array}{l}\text { Ensaios de resistência e de de alteração obtidos pela } \\
\text { deformabilidade }\end{array}$ & $\begin{array}{l}\text { comparação entre os resultados dos } \\
\text { ensaios mecânicos da rocha alterada e } \\
\text { dasã }\end{array}$ \\
\hline
\end{tabular}

Devido os maciços rochosos sofrerem diversas mudanças de características, diferindo de local para local, função da história geológica de sua formação, é necessário se fazer uma caracterização geológica geotécnica, a fim de evidenciar os atributos do meio rochoso que, isoladamente ou conjuntamente, condicionam o seu comportamento ante as solicitações impostas pela obra. $\mathrm{O}$ ato de hierarquizar essas características e organizá-las individualmente em grupos ou classes, as quais possa se associar comportamentos diferenciados do meio rochoso é denominado de classificação geomecânica do maciço.

Apesar da existência de inúmeras classificações geomecânicas na bibliografia especializada, atualmente apenas as classificações de Bieniawski (1979) (Sistema RMR), e a de Barton et al. (1974) (Sistema Q), são corriqueiramente as mais utilizadas. Tanto o "Q" como o "RMR" se utilizam de parâmetros geológicos, geométricos e de solicitações do projeto de engenharia, com o objetivo de obter um valor quantitativo, que descreva a qualidade geomecânica do maciço.

Segundo Bieniawski (1989), as classificações geomecânicas não devem ser tomadas por um substituto do projeto de engenharia, pois elas representam uma abordagem empírica, sendo necessária uma abordagem observacional e analítica de todo o projeto.

As classificações geomecânicas fornecem uma boa aproximação das condições de qualidade do maciço rochoso, prevendo o tipo de tratamento necessário para cada setor das escavações e emque quantidade, porém não 
antecipam problemas mais pontuais, sendo necessária uma abordagem mais detalhada das características geológico geotécnicas do maciço, realizada por observações de campo em conjunto com análise petrográfica, análise do material fino eanálise das características geomecânicas do maciço. 
3

MATERIAIS E MÉTODOS UTILIZADOS NA AVALIAÇÃO DA ALTERAÇÃO HIDROTERMAL DAS ROCHAS DE UM TÚNEL NO BAIRRO DE JACAREPAGUÁ

O presente capítulo apresenta os procedimentos experimentais realizados durante o trabalho, que tem como objetivo investigar a influência das alterações químico mineralógicas na resistência dos maciços rochosos. Todos os ensaios foram realizados no Laboratório de Geotecnia e Meio Ambiente da PUC - Rio e no Centro Tecnologia Mineral do Rio de Janeiro (CETEM).

\subsection{MATERIAIS}

Para o estudo e a avaliação do comportamento dos diferentes níveis de alterações foram utilizadas amostras de um túnel no bairro de Jacarepaguá. Durante os trabalhos de campo foram visitados diversos pontos na frente de escavação e nas áreas adjacentes ao túnel, onde foram coletadas diversas amostras tanto na parte de dentro do túnel e por vezes no "bota fora", cuidando-se para obter um conjunto representativo dos variados litotipos presentes na área de escavação, em diferentes estágios de alteração, tal como mostrado na tabela 7. No trabalho de campo foram coletadas diversas amostras de diferentes litotipos, que foram divididas em cinco conjuntos, tentando representar diferentes graus de alteração para um mesmo litotipo (sã, medianamente alterada e alterada). Porém, devido à complexidade da obra e a dificuldade de se obter amostras dentro do túnel, alguns litotipos não puderam ser amostrados dessa forma, contando apenas com uma amostra sã ou uma amostra medianamente alterada ou uma amostra alterada.

As amostras foram coletadas na frente de escavação, no emboque e no "bota fora", devido à velocidade de conclusão da obra não foi possível um controle estrutural desse material dentro do túnel, sendo assim as amostras não puderam ser localizadas espacialmente a não ser de uma maneira puramente descritiva das diferentes estruturas primarias e secundárias. 
Na tabela 7 são apresentadas as identificações das amostras estudadas bem como sua classificação com base no grau de alteração segundo o IPT, 1984 (tabela 6).

TABELA 6 - Graus de alteração de rocha (IPT, 1984, apud Serra Junior e Ojima, 1988)

\begin{tabular}{|c|c|}
\hline Denominação & Caracteristicas da rocha \\
\hline $\begin{array}{c}\text { Sã ou } \\
\text { praticamente sã }\end{array}$ & $\begin{array}{c}\text { Apresenta minerais primários sem vestigios de alterações ou com } \\
\text { alteraçóes fisicas e quimicas insipientes. Neste caso a rocha é } \\
\text { ligeiramente descolorida. }\end{array}$ \\
\hline $\begin{array}{c}\text { Moderadamente } \\
\text { alterada }\end{array}$ & $\begin{array}{c}\text { Apresenta minerais moderadamente alterados e a rocha é bastante } \\
\text { descolorida. }\end{array}$ \\
\hline $\begin{array}{c}\text { Muito alterada } \\
\text { Extremamente } \\
\text { alterada }\end{array}$ & $\begin{array}{c}\text { Apresenta minerais muito alterados, por vezes pulverulentos e } \\
\text { friáveis. }\end{array}$ \\
\hline
\end{tabular}

TABELA 7 - Identificação das amostras coletadas no campo, bem como sua alteração a vista desarmada de acordo com a classificação do IPT, 1984.

\begin{tabular}{|c|c|c|c|}
\hline CONJUNTO & $\begin{array}{c}\text { IDENTIFICAÇÃO } \\
\text { DAS AMOSTRAS }\end{array}$ & LITOTIPO & GRAU DE ALTERAÇÃO \\
\hline \multirow{2}{*}{1} & 02 & Diorito & Rocha sã \\
\hline & 24 & Diorito & Rocha alterada \\
\hline \multirow{3}{*}{2} & 03 & Basalto & Rocha sã \\
\hline & 07 & Basalto & Rocha medianamente alterada \\
\hline & 11 & Traquito & Rocha alterada \\
\hline \multirow{3}{*}{3} & 21 & Granodiorito gnaisse & Rocha sã \\
\hline & 20 & Granodiorito gnaisse & Rocha medianamente alterada \\
\hline & 22 & Granodiorito gnaisse & Rocha alterada \\
\hline \multirow{3}{*}{4} & 01 & $\begin{array}{l}\text { Biotita granada } \\
\text { gnaisse }\end{array}$ & Rocha sã \\
\hline & 23 & $\begin{array}{l}\text { Biotita granada } \\
\text { gnaisse }\end{array}$ & Rocha medianamente alterada \\
\hline & 25 & $\begin{array}{l}\text { Biotita granada } \\
\text { gnaisse }\end{array}$ & Rocha alterada \\
\hline \multirow{3}{*}{5} & 04 & Anfibolito & Rocha alterada \\
\hline & 08 & Granito & Rocha sã \\
\hline & 10 & Biotita gnaisse & Rocha alterada \\
\hline
\end{tabular}




\subsubsection{CONTEXTO GEOLÓGICO LOCAL}

Por conta dos cortes realizados para a abertura da via e do túnel a geologia local poderia ser feita de forma privilegiada. Entretanto, a velocidade de avanço das obras e a complexidade de se trabalhar e se manter dentro da área de execução da obra, não permite que se tenha um mapeamento geológico satisfatório e um controle estrutural sobre as amostras. Entretanto, a região limítrofe a via nos permite verificar, estudar e aprender sobre a geologia local, através do exame de afloramentos e frentes de pedreiras ativas e inativas da região.

Segundo Porto Jr. (2004), a sequência gnáissica atravessada pelo túnel no bairro de Jacarepaguá, bem como as áreas adjacentes, integra totalmente o Complexo Pedra Branca (CPB).

Esta sequência gnáissica foi subdividida em duas unidades de mapeamento: Unidade Kinzigítica (UnKinz), composta por um biotita-granada gnaisse com subordinadas lentes de rochas calcissilicáticas e Unidade Ortoderivada (UnOrt), compreendida por gnaisses semifacoidais de composições que variam de quartzo-diorítica/ tonalítica a granítica (Esteves et al. 2001).

Assim é possível se definir a presença de um conjunto gnáissico compreendido por litotipos de cor cinza predominante, foliados a bandados e de variações texturais e composicionais conspícuas. Estes litotipos foram estratigraficamente assim definidos do mais antigo para o mais recente: biotitagranada gnaisse, com rochas calcissilicáticas subordinadas (UnKinz), plagioclásio gnaisse, diorito gnaisse, microclima gnaisse e tonalito glomeroporfirítico (UnOrt) (Almeida, 1999 apud Porto Jr, 2004).

Dioritos e quartzo dioritos (Diorito Sulacap) apresentam restrita distribuição areal. É mais bem observado em afloramentos no flanco norte da Serra do Engenho Velho (Antiga Pedreira Embrasa em área ocupada hoje, parcialmente pelo supermercado Carrefour), sob a forma de um corpo tabular com cerca de 40 metros de largura, e de "plugs", entrecortado por veios félsicos aplíticos. Apresenta ampla variação textural e ocorre intrudindo os gnaisses ortoderivados ali representados, por biotita gnaisse (quartzo diorito gnaisse) e pelos gnaisses semifacoidais a plagioclásio e microclima (Valeriano et al., 2012). 
Associados a estas rochas, ocorrem xenólitos anfibolíticos e rochas granitóides intrusivas em estágios cronologicamente distintos. Estas últimas correspondentes aos litotipos: leucogranito (ULc), facies pegmatítica e nebulítica, Granito Pedra Branca (UGPB) facies pegmatítica e Biotita Granito, facies equigranular (UBg). Diques centimétricos a métricos de fonolito e/ou traquito e diabásio foram observados cortando todo o conjunto.

\section{ASPECTOS DE CAMPO DA UNIDADE KINZIGÍTICA}

Segundo Porto Jr. (2004), a UnKinz, isolada no interior da Unidade Ortoderivada, possui expressão areal e volumétrica restrita. É predominantemente composta pelo biotita-granada gnaisse (Kinzigítico), leuco a mesocrático, granoblástico a granoporfiroclástico, foliado a bandado, e de variações texturais conspícuas (Figura 5). Sua composição mineral é dada pela presença de plagioclásio, quartzo, biotita e microclima. Almandina, zircão, apatita, minerais opacos, titanita e espinélio ocorrem como minerais acessórios.

Essa rocha pode apresentar localmente enriquecida em porfiroclastos centimétricos de almandina de até $3 \mathrm{~cm}$, dispersos de maneira irregular na matriz, ou preferencialmente associada à leucossomas granatíferos de origem possivelmente anatética.

A intercalação de leucossomas granatíferos "boudinados" e venulações quartzo-feldspáticas, com bandas máficas ricas em biotita refratária, conferem um padrão migmatítico do tipo "schollen" ao conjunto.

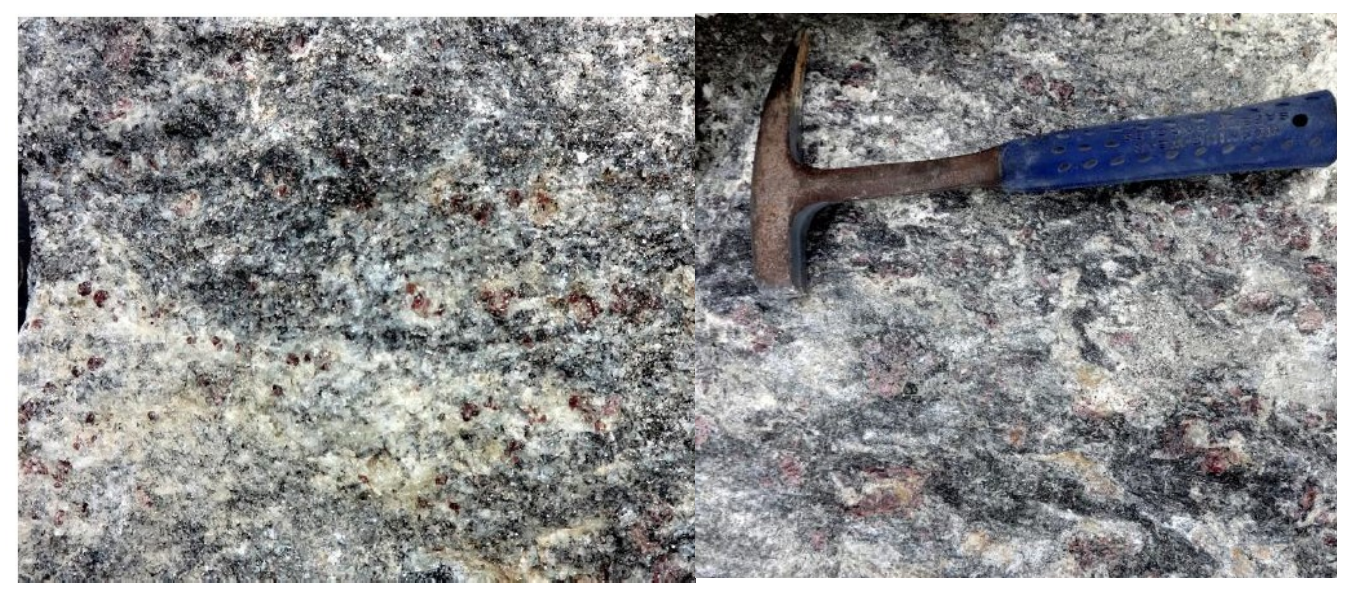

FIGURA 5 - Aspecto do gnaisse kinzigitico no campo. Vale ressaltar a grande quantidade de granada presente. 


\section{ASPECTOS DE CAMPO DA UNIDADE ORTODERIVADA}

Esta série foi definida como correspondendo a um conjunto de rochas gnáissicas e migmatíticas de caráter magmático, incluindo gnaisses de composição básica à intermediária foliada.

Porto Jr. (2004) aponta para um padrão estratigráfico definido onde, da base para o topo, ocorre biotita gnaisse (composição quartzo diorítica a diorítica) intensamente deformado e migmatizado, apresentando dobras intrafoliais apertadas, com padrões de interferência de dobramentos e com conspícua transposição da foliação. Trata-se de rocha fortemente bandada, migmatizada e, considerando-se o intenso nível de deformação, pode ser assumido que o bandamento, com segregação de leitos félsicos e máficos, seja fruto de diferenciação metamórfica. A paragênese metamórfica mais comum é composta de quartzo + plagioclásio + hornblenda + biotita $(+/-$ ortoclásio/microclima) (Figura 6).

Feições de anatexia são evidentes em associação a este litotipo. Quando na região de contato com as rochas graníticas (granito Pedra branca) é comum o aparecimento de estruturas fantasmas, "schilierens", estruturas "schollen", zonas nebulíticas e zonas de enclaves xenolíticos, que apresentam variados graus de assimilação. Ainda na região de contato, processos de migmatização podem ser intensos o suficiente para gerar uma homogeneização completa dos materiais envolvidos. Cisalhamentos são bastante comuns, estando, em geral, seus planos preenchidos por material pegmatítico ou aplítico proveniente da intrusão Pedra Branca, bem como por leucossomas produzidos durante a migmatização.

Subindo na estratigrafia, tem-se um ortoclásio (microclima-quartzo gnaisse de composição granodioritica, de tons acinzentados, cuja paragênese metamórfica principal é quartzo + ortoclásio + plagioclásio + biotita com eventual granada. Tem indiscutível origem magmática, pois são observados diversos enclaves de biotita gnaisse em seu domínio. Menos deformado, ainda assim apresenta foliação bastante evidenciada. Cisalhamentos localizados e dobras suaves são identificados. Apresenta esparsos porfiroblástos de microclina (figura 6) sombras de pressão e sobressaem a uma matriz de granulometria média e homogênea, onde predominam o quartzo e o plagioclásio com biotita e ortoclásio em volumes subordinados, não apresentando anfibólio. Intrusivo nos conjuntos 
anteriormente descritos ocorrem rochas anfibolíticas. Estas ocorrem sob duas formas distintas: a) como melanossoma de migmatitos e b) sob forma de pequenos diques e soleiras intrusivos nas rochas migmatizadas interestratificadas nos gnaisses mais antigos, apresentando-se em geral, "boudinados", milonitizados e estirados ao longo dos planos de foliação principal dos gnaisses hospedeiros. As paragêneses metamórficas mais comuns na este litotipo são: plagioclásio + hornblenda (+/- quartzo) e quartzo + plagioclásio + hornblenda + biotita (+/ortoclásio/microclina).

O tipo gnáissico mais jovem tem composição quartzo diorítica a tonalítica, tons claros, sendo caracteristicamente rico em grumos de material máfico (textura glomeroporfiroblástica) o que lhe confere em aspecto mosqueado, sendo a biotita o mineral máfico mais abundante. A paragênese metamórfica típica é composta de quartzo + plagioclásio + biotita (+/- ortoclásio/microclima). É o tipo menos deformado dentre os gnaisses e também o de ocorrência mais restrita na área.

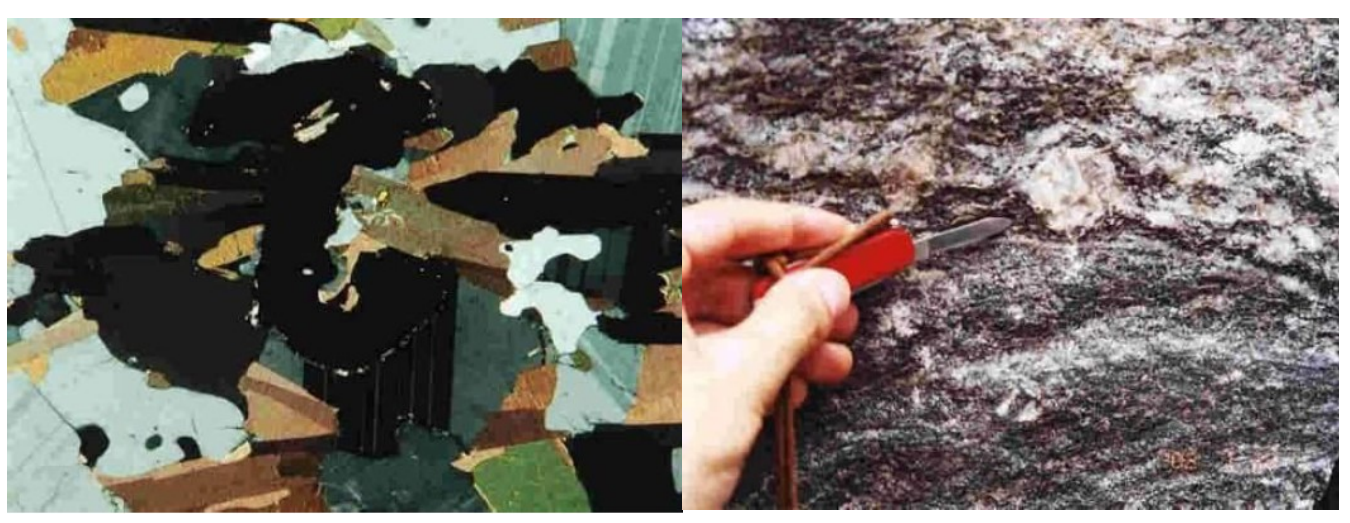

FIGURA 6 - Aspecto da paragênese do biotita gnaisse (esquerda) e porfiroblásto de microclina em biotita gnaisse (direita).

\subsection{CARACTERIZAÇÃO DOS MATERIAIS}

\subsubsection{ANÁLISE PETROGRÁFICA}

A caracterização mineralógica, química e textural têm grande importância nos estudos das propriedades e comportamento geotécnico de maciços rochosos, 
devido à natureza de diversas alterações que esses maciços sofreram ao longo do tempo geológico.

O estudo petrográfico é fundamental para a compreensão do comportamento físico-mecânico e de susceptibilidade à alteração, dentre outras (Costa, 2007). Portanto, quanto mais diversificados os métodos usados na investigação mineralógica, melhores serão as interpretações dos resultados de caracterização tecnológica, o que facilita a solução de problemas que porventura venham a surgir antes, durante ou após a escavação de maciços rochosos.

Nesta parte do trabalho, as amostras foram enviadas para o laboratório de laminação da faculdade de geologia da Universidade Federal do Rio de Janeiro (UFRJ) para confecção das lâminas petrográficas.

A. Em seguida as amostras foram analisadas macroscopicamente com utilização de lupa 10/20x e microscopicamente através de microscópio ótico com luz polarizada da marca Olympus, modelo CX31 com câmera (SC-30) acoplada para geração de imagens diretamente do microscópio no laboratório de Geotecnia da PUC-RJ (figura 7).

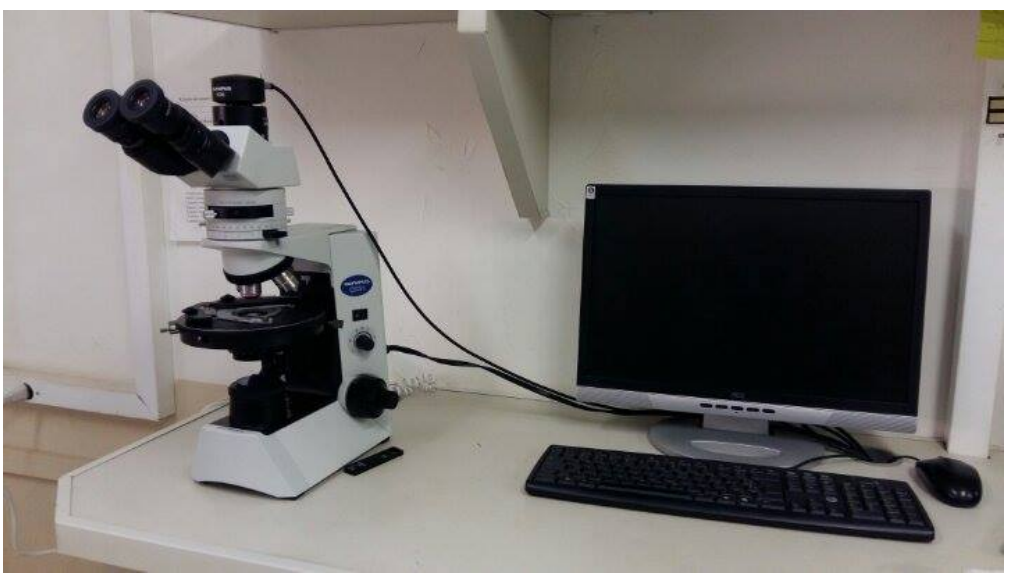

FIGURA 7 - Aspecto do equipamento de análise microscópica de rochas do laboratório de Geotecnia da PUC - Rio.

B. Em cada lâmina petrográfica foram efetuadas análises de 20 pontos, visando basicamente definir a descrição da composição mineralógica, tamanho dos minerais, forma e relação dos contatos e os vários tipos de alteração associados, que compreendeu na 
aquisição de fotomicrografias e contagem modal seguida de classificação litológica.

\subsubsection{ANÁLISE DE RAIOS $X$}

A difratometria de Raios-X corresponde a uma das principais técnicas de caracterização microestrutural de materiais cristalinos, encontrando aplicações em diversos campos do conhecimento, mais particularmente na engenharia e ciências de materiais, engenharias metalúrgicas, química e de minas, além de geociências, dentre outros.

Através da difratometria de raios-x (DRX) foram identificados os componentes minerais das amostras, basicamente minerais argilosos frutos de alterações hidrotermais.

Para isto, o material argiloso foi isolado dasamostras por diversos procedimentos citados a seguir:

1) Primeiramente as amostras foram destorroadas no almofariz de ágata, para evitar contaminação.

2) Logo após destorroar as amostras, elasforam passadas na peneira ABNT $\mathrm{n}^{\circ} 200$ (abertura de $0,074 \mathrm{~mm}$ ) e submetidas às seguintes condições de tratamentos: aquecimento na mufla a $350^{\circ}$ e $550^{\circ}$ Celsius e caso haja dúvidas a respeito de algumas fases mineralógicas, especialmente as fases expansivas, será feito o uso da adição de etileno glicol.

O etileno glicol provoca expansão das camadas de alguns angstroms $(1 \AA$ $=10^{-8} \mathrm{~mm}$ ), em alguns argilominerais enquanto o aquecimento provoca contração das camadas em outros. Os comportamentos nestas condições são comparados com o comportamento do material ao natural, a fim de ter uma melhor interpretação das fases mineralógicas existentes. A tabela 8 apresenta uma síntese simplificada do comportamento dos argilominerais mais frequentes ante esta técnica de identificação. (Modificado de Frazão, 2012). 
TABELA 8 - Procedimento para identificação de argilominerais por difratometria de raios-x (modificada de Frazão, 2012).

\begin{tabular}{|l|c|c|c|c|}
\hline \multirow{2}{*}{ GRUPO } & \multicolumn{4}{c|}{ TRATAMENTOS } \\
\cline { 2 - 5 } & Natural* & Etilenoglicol* & $\begin{array}{c}\text { Aquec. } \\
350 \% / 3,5 \mathrm{~h}^{*}\end{array}$ & $\begin{array}{l}\text { Aquec. } \\
550^{\circ} / 3,5 \mathrm{~h}^{*}\end{array}$ \\
\hline Caulinita & $\sim 7 \AA$ & $\sim 7 \AA$ & $\sim 7 \AA$ & amorfização \\
\hline Ilita & $\sim 10 \AA$ & $\sim 10 \AA$ & $\sim 10 \AA$ & $\sim 10 \AA$ \\
\hline Clorita & $\sim 14 \AA$ & $\sim 14 \AA$ & $\sim 14 \AA$ & $\sim 14 \AA$ \\
\hline Vermiculita & $\sim 14 \AA$ & $\sim 14 \AA$ & $\sim 10 \AA$ & $\sim 10 \AA$ \\
\hline Esmectita & $\sim 14 \AA$ & $\sim 17 \AA$ & $\sim 10 \AA$ & $\sim 10 \AA$ \\
\hline
\end{tabular}

*Nota: Espaçamentos interplanares; $\AA$ : Angstrom $\left(1 \AA=10^{-8} \mathrm{~mm}\right)$

Utilizou-se os equipamentos de Difração de Raios-X do Centro de Tecnologia Mineral (CETEM) e do Laboratório da PUC-RJ. Os difratogramas das amostras, obtidas pelo método do pó, foram coletados em um equipamento Bruker-D4 endeavor, nas seguintes condições de operação: radiação Co $\mathrm{K} \alpha(40$ $\mathrm{Kv} / 40 \mathrm{~mA}$ ), velocidade do goniômetro de $0,02^{\circ} 2 \theta$ por passo com tempo de contagem de 0,5 segundos por passo e coletados de 5 a $80^{\circ} 2 \theta$, com detector sensível à posição Iynxeye. As interpretações qualitativas de espectro foram efetuadas por comparação com padrões contidos no banco de dados PDF02 (ICDD, 2006) em software BrukerDiffrac ${ }^{\text {Plus }}$.

A identificação dos minerais é feita por intermédio de picos produzidos pela difração, que são registrados em gráficos e correspondem a vários ângulos de um goniômetro, a partir dos quais o espaçamento cristalográfico do mineral pode ser calculado pela lei de Bragg. Esta determinação pode ser feita por tabelas ou programas de bancos de dados, nesse trabalho optou-se em trabalhar com os dois métodos.

Analisando-se os difratogramas obtidos optou-se por realizar aquecimento nas amostras $03,04,07,10,11,24,25$. O aquecimento foi feito na mufla em duas etapas: $350^{\circ} \mathrm{C}$ por 3,5 horas e $550^{\circ} \mathrm{C}$ por 3,5 horas. A técnica de aquecimento foi suficiente para caracterizar a maioria das fases de argilominerais presentes, porém duas amostras necessitavam da confirmação com tratamento por etileno glicol para se tirar a dúvida em relação a sua fase mineralógica. Por conta 
do prazo de apresentação do trabalho, essa análise ficou programada para posteriormente a apresentação.

\subsubsection{RESISTÊNCIA À COMPRESSÃO PUNTIFORME}

Segundo Rusnak (2000) a resistência à compressão puntiforme (Point Load Test) é um método simples, rápido e barato para a obtenção de valores de resistência das rochas (figura 8). Muitos pesquisadores relataram diversos trabalhos a respeito do processo do ensaio, o efeito de diferentes configurações de cargas, tamanho das amostras e a necessidade de fatores de correção de tamanho.

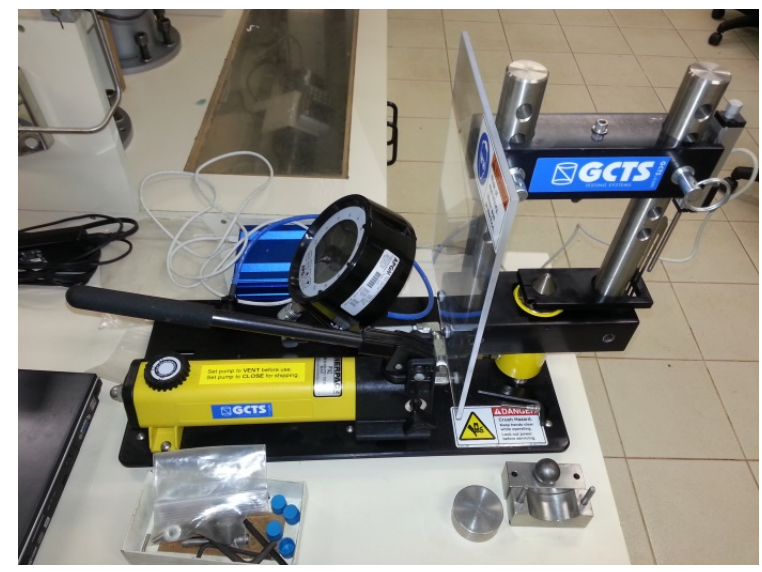

FIGURA 8 - Equipamento de resistência à compressão puntiforme (Point Load Test) do laboratório de geotecnia da PUC - Rio.

Publicações de Broch e Franklin (1972), Guidicini et al. (1973) e Bieniawski (1975) definiram o método de resistência à compressão puntiforme como um método conveniente para a classificação de resistência das rochas. Em particular, a investigação abrangente por Broch e Franklin (1972) provou que este método seja de tal potencial na mecânica das rochas e geologia de engenharia que foram tomadas medidas para padronizar os procedimentos de análise por parte da Sociedade Internacional de Mecânica das Rochas (ISRM de 1973).

Os ensaios obedeceram à norma técnica americana da ASTM D5731-95 e foram realizados no Laboratório de Geotecnia e Meio Ambiente da PUC-RJ.

O teste é uma consequência de experimentos com a compressão de amostras cilíndricas ou irregulares de rocha, na qual se constatou que a magnitude 
da carga aplicada no instante de ruptura esta relacionada tanto com a resistência à tração $(T o)$ quanto com a resistência à compressão uniaxial $(\sigma c)$.

O ensaio é em geral realizado no campo, em amostras de rochas despreparadas, por ser um equipamento simples e de fácil locomoção. Em essência, este teste envolve a compressão de um pedaço de rocha entre dois pontos. O ponto de índice de carga (Is) é calculado como a razão entre a carga aplicada $\mathrm{P}$ para o quadrado da distância $\mathrm{D}$ entre os pontos de carga. As dimensões do carregamento "pontos" são padronizadas (ASTM, 1995).

$$
I s=P / D^{2}
$$

Portanto o ensaio é usado para calcular o índice de tensão de carga pontual (Is) e também para se estimar a tensão de compressão de uma amostra de rocha $(\sigma c)$.

DIAMETRAL

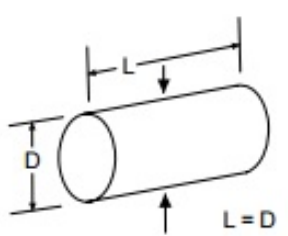

AXIAL

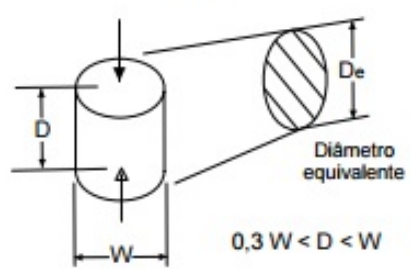

BLOCO

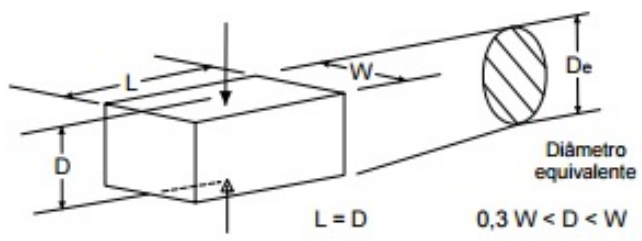

IRREGULAR

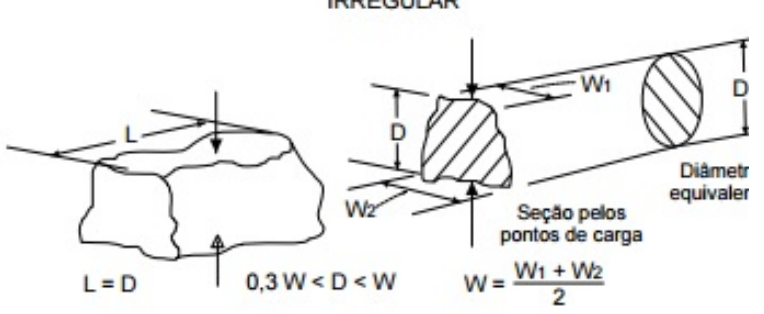

FIGURA 9 - Forma da amostra e tipo de compressão puntual indicado. (ISRM, 1995)

Com o intuito de se obter um valor único de Is para diversos corpos de provas de dimensões diferentes, há a necessidade de se determinar o fator de correção de tamanho (F) com o qual, obtém-se o Índice de Carga Pontual 
corrigido $\left(\mathrm{Is}_{50}\right)$. O Is $\mathrm{I}_{50}$ de um corpo de prova qualquer é definido como o valor de Is para uma medida diametral de $50 \mathrm{~mm}(\mathrm{De}=50 \mathrm{~mm})$ e pode ser obtido de acordo com a equação abaixo.

$$
\mathrm{F}=(\mathrm{De} / 50)^{1 / 2}
$$

Estima-se o valor da tensão de compressão uniaxial do material através da relação:

$$
\sigma \mathrm{c}=\mathrm{C} . \operatorname{Is}(50)
$$

Onde: $\sigma c=$ Tensão de compressão uniaxial

$\mathrm{C}=$ Fator que depende da correlação entre $\sigma \mathrm{c}$ e $\mathrm{Is}_{50}$ para um maciço rochoso especifico.

TABELA 9 - Valor geral de C em função do De (ASTM, 1995)

\begin{tabular}{|c|c|}
\hline $\mathbf{D}_{\text {e médio }}(\mathbf{m m})$ & $\mathbf{C}$ \\
\hline 20 & 17,5 \\
\hline 30 & 19 \\
\hline 40 & 21 \\
\hline 50 & 23 \\
\hline 54 & 24 \\
\hline 60 & 24,5 \\
\hline
\end{tabular}


4

RESULTADOS

\subsection{CARACTERIZAÇÃO DA ALTERAÇÃO HIDROTERMAL NAS ROCHAS DO TÚNEL DA REGIÃO DE JACAREPAGUÁ}

Neste subcapítulo são apresentados os resultados referentes às condições de alteração do conjunto de amostras, com o objetivo de tentar correlacionar as condições de alteração que o conjunto sofreu através dos aspectos gerais da textura, granulação e das estruturas penetrativas.

As amostras da parte interna do túnel, separadas em cinco conjuntos, não apresentaram sinais de transformação intempérica, portanto assume-se que toda alteração tenha sido proveniente de transformações de interações hidrotermais associados a padrões estruturais impostos à rocha. A seguir segue a descrição dos conjuntos, junto com o padrão de transformação a eles observados. Os dados da tabela de alteração hidrotermal serão compilados segundo campos (2007). De acordo com o aspecto tátil e visual que a amostra apresenta e fazendo uso da tabela de graus de alteração de rocha (IPT, 1984, apud Serra Junior e Ojima, 1988), as rochas foram classificadas como sã, medianamente alterada e alterada.

\subsubsection{Conjunto 01 - Amostras Unidade Ortoderivada}

As amostras da Unidade Ortoderivada, que compunham o Conjunto 01, de acordo com o aspecto tátil visual foram classificadas como rocha sã (02) e rocha alterada (24). Com base na análise microscópica sua composição é dada por plagioclásio, biotita, hornblenda, microclina e quartzo como minerais essenciais, apatita, zircão, titanita e minerais opacos como minerais acessórios principais, carbonato, muscovita e argilominerais, induzidos por ação hidrotermal e/ou deformação dinâmica. Ambos os litotipos foram classificados como Diorito. 


\section{\#Amostra 02}

\section{Microscopia}

As principais alterações no litotipo (02) mostram que alguns grãos de plagioclásio apresentam Saussuritização que é um processo de alteração hidrotermal onde o plagioclásio, por hidratação, se transforma em um agregado formado por uma mistura de calcita, sericita ou epidoto. É possível ainda observar alteração do plagioclásio em sericita (sericitização), onde a transformação se dá preferencialmente, a partir de planos de geminação (controlados pela Lei da Albita) e pelos planos de clivagem em muito poucos cristais observa-se formação de muscovita. A biotita mostra-se pouco alterada, porém alguns grãos apresentam alta cor de interferência o que pode apontar para a possibilidade da rocha ter sofrido processos de alterações hidrotermais incipientes

As fases secundárias formadas por processos de transformação mineral surgem a partir da transformação da biotita em muscovita que cresce preferencialmente nos planos de clivagens. Em poucos casos, microfissuras nos grãos de plagioclásio favorecem a percolação de fluídos alterando-os. Sendo assim, existe a tendência desse grão de plagioclásio se transformar, inicialmente de maneira pontual, em minerais como mica branca (ilita $\rightarrow$ sericita $\rightarrow$ muscovita), carbonato e epidoto. O que definirá a presença de grãos individualizados de cada uma dessas fases secundárias é a intensidade do processo. Assim para a amostra estudada pode ser afirmado que se trata de um processo de baixa intensidade hidrotermal, visto que poucos são os grãos com tais características.

A fase mineral carbonática (calcita) apresenta volume restrito, preenchendo as microfissuras nos grãos de plagioclásio.

\begin{tabular}{|lll|c|}
\hline $\begin{array}{l}\text { Processo } \\
\text { Observado }\end{array}$ & \multicolumn{1}{c|}{ Transformação Observada } & $\begin{array}{l}\text { Grau de } \\
\text { Intensidade }\end{array}$ \\
\hline & Muscovitização: & $\begin{array}{l}\text { Plagioclásio } \rightarrow \text { Muscovita } \\
\text { Biotita } \rightarrow \text { Muscovita }\end{array}$ & $\begin{array}{l}\text { Fraco } \\
\text { Fraco }\end{array}$ \\
& Sericitização: & Plagioclásio $\rightarrow$ Sericita & Fraco \\
& Carbonatização: & Plagioclásio $\rightarrow$ Carbonato & Fraco \\
\hline
\end{tabular}




\section{\#Amostra 24}

\section{Microscopia}

As principais alterações no litotipo (24) mostram que diversos grãos de plagioclásio não apresentam geminação, devido a processos de forte alteração predominantemente por argilização, sericitização e sausuritização, por vezes substituindo totalmente o grão restando apenas pseudomorfos dos mesmos. Podese notar duas fases de cristalização da biotita, uma primeira de aspecto límpido sem inclusões ou transformações e uma segunda com padrão conhecido como "birds eyes" que caracteriza o início do processo de transformação pela entrada de água nos retículos de sua estrutura. Chama-se atenção para a grande quantidade de minerais opacos e/ou inclusões formados pela ação hidrotermal nos grãos de biotita, sendo considerável a transformação de biotita para clorita (cloritização). A hornblenda ocorre parcialmente alterada para clorita e poucos casos sendo substituída por biotita.

As fases secundárias formadas por processos de transformação mineral ocorrem a partir da transformação do plagioclásio em sericita, epidoto e saussurita. Devido à intensidade da alteração foram gerados grãos pseudomorfos, sendo comum a perda da geminação do grão. A muscovita cresce nos planos de clivagens, plano preferencial para migração de fluídos de forma intracristalina, e nas bordas de grãos de biotita e na substituição de grãos de plagioclásio por alteração hidrotermal (muscovitização), desta forma, fases mineralógicas menos estáveis se transformam à medida que esses fluídos penetram. Argilominerais também se formam a partir da alteração do anfibólio gerando grãos pseudomorfos, onde a hornblenda é substituída intensamente por clorita e sericita. Observa-se grande perda da mineralogia e textura primária, gerando um aspecto desbotado em sua matriz. 


\begin{tabular}{|l|ll|c|}
\hline $\begin{array}{l}\text { Processo } \\
\text { Observado }\end{array}$ & \multicolumn{2}{|c|}{ Transformação Observada } & Grau de Intensidade \\
\hline & Muscovitização: & $\begin{array}{l}\text { Plagioclásio } \rightarrow \text { Muscovita } \\
\text { Biotita } \rightarrow \text { muscovita }\end{array}$ & $\begin{array}{c}\text { Moderado } \\
\text { Fraco a Moderado }\end{array}$ \\
& Sericitização: & $\begin{array}{l}\text { Plagioclásio } \rightarrow \text { sericita } \\
\text { Anfibólio } \rightarrow \text { sericita }\end{array}$ & $\begin{array}{c}\text { Intenso } \\
\text { Moderado }\end{array}$ \\
Hidrotermal & Cloritização: & $\begin{array}{l}\text { Biotita } \rightarrow \text { clorita } \\
\text { Anfibólio } \rightarrow \text { clorita }\end{array}$ & $\begin{array}{c}\text { Intenso } \\
\text { Intenso }\end{array}$ \\
& Epidotização: & Plagioclásio $\rightarrow$ Epidoto & Moderado a intenso \\
\hline
\end{tabular}



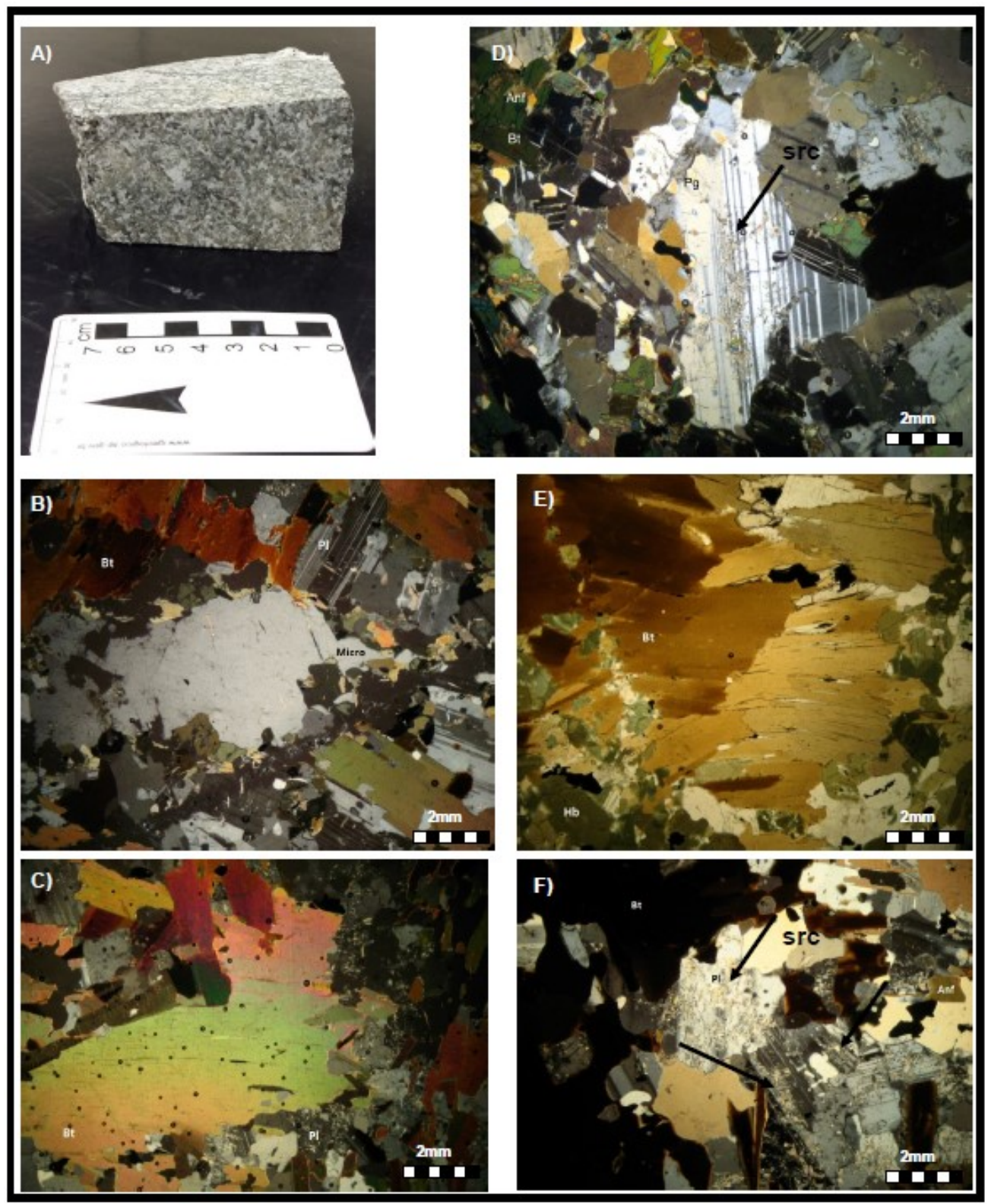

FIGURA 10 - Fotomicrografias da amostra 02. a) Litotipo 02 (diorito sã); b) Grão de microclina límpido, sem alterações, luz polarizada; c) início da transformação do grão de biotita, luz polarizada; d) Início do processo de sausuritização no grão de plagioclásio, luz polarizada; e) grãos de biotita deformados, causados provavelmente por processos intracristalinos, induzidos por "stress", luz natural; f) detalhe da alteração dos grãos de plagioclásio (sausuritização) formando calcita, sericita e epidoto, luz polarizada. Legenda: pl: plagioclásio; ms: muscovite; hb/anf: hornblenda ou anfibólio; clr: clorita; bt: biotita; micro: microclina; src: sericita. 


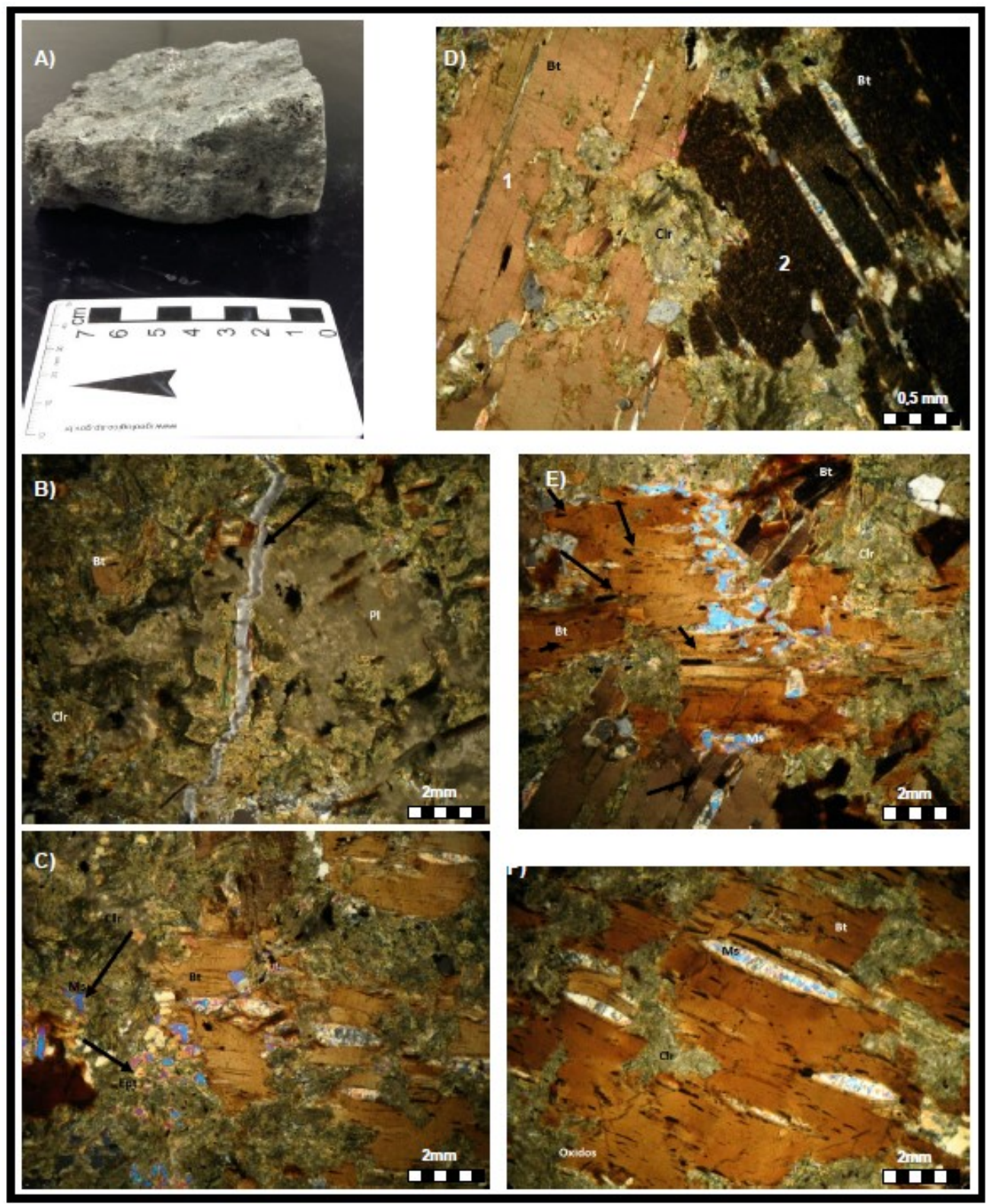

FIGURA 11 - Fotomicrografias da amostra 24. a) Litotipo 24 (diorito alterado);

b) aspecto geral da matriz alterada com microfratura preenchida por silica, luz polarizada; c) intensa alteração do plagioclásio, hornblenda e biotita, luz polarizada; d) diferentes estágios de transformação dos grãos de biotita. 1) grão levemente alterado; 2) grão com formação de "birds eyes" (entrada de água) dando inicio ao processo de transformação para clorita/ sericita, tais processos estão associados a hidrotermalismo progressivo, luz polarizada; e) observar grande quantidade de óxidos nos planos de clivagem da biotita, luz polarizada; f) formação de muscovita nos grãos de plagioclásio, geração de clorita e óxidos através da alteração da hornblenda e biotita apontando para a intensidade do 
processo hidrotermal, luz polarizada. Legenda: pl: plagioclásio; ms: muscovite; ept: epidoto; clr: clorita; bt: biotita.

\subsubsection{CONJUNTO 02 - Amostras Unidade de rochas vulcânicas básicas}

Três amostras foram examinadas para litotipo e de acordo com o aspecto tátil visual foram classificadas como rochanão alterada (03), rocha medianamente alterada (07) e rocha alterada (11). A seguir segue a descrição detalhada de suas características.

\section{\#Basalto 03}

\section{Microscopia}

Há uma paragênese de alteração hidrotermal marcante, definida por minerais opacos, sericita, serpentina e epidoto. O plagioclásio com frequência apresenta-se sausuritizado (carbonato) tanto no centro quanto em sua borda, sendo frequente a inclusão parcial e ocasionalmente sobrecrescimento de alguns grãos de piroxênio. O piroxênio ocasionalmente apresenta-se com bordas de reação formadas por anfibólio (uralitização) e se encontra alterado para clorita, serpentina, talco e óxido/hidróxido de ferro. Os minerais opacos se manifestam de duas maneiras: uma geração primária com hábito subédrico, formato arredondado e sobrecrescido no piroxênio e muitas vezes formando pseudomorfos desse mineral e uma secundária quando ele apresenta hábito esqueletal preenchendo os espaços intersticiais da rocha.

As fases secundárias aparecem nas raras transformações do grão de plagioclásio em sericita que tem hábito acicular e granulação fina, ocorre preenchendo microfissuras ao longo dos planos de clivagens e planos de geminação, além de sausuritização em grãos fissurados. Epidoto anédrico ocorre raramente associado à sericita como produto da sausuritização do plagioclásio. Os grãos de piroxênio por vezes estão substituídos por grãos de hornblenda (uralitização). 


\section{\#Basalto 07 e Traquito11}

\section{Microscopia amostra (07)}

A rocha apresenta textura holocristalina intergranular, definida por cristais granulares de piroxênio e finos cristais de plagioclásio de hábito tabular dispostos aleatoriamente na matriz junto com minerais opacos. É possível identificar algumas microfissuras cortando a rocha, geralmente preenchidas por materiais amorfos ou secundários de cor amarelada.

O plagioclásio em geral apresenta-se alterado perdendo suas propriedades óticas inerentes. É possível observar o crescimento de muscovita e epidoto como subproduto da alteração parcial dos seus grãos. Raros fenocristais são observados, alguns são cortados por microfissuras preenchidas por material amorfo. Parte dos grãos de piroxênio está alterada com cores de interferência amarelo amarronzadas sugerindo a ocorrência de fases minerais como a biotita, alguns grãos aparecem escuros devido à oxidação e alguns transformados para serpentina (serpentinização).

As fases secundárias formadas por processos de transformação mineral surgem a partir da transformação do plagioclásio em muscovita que cresce preferencialmente nos planos de clivagens junto com epidoto (epidotização), ocorre também transformações nas bordas e planos de clivagens de alguns grãos de piroxênios sugerindo o aparecimento de fases de biotita e serpentina como produto dessa alteração. A rocha apresenta microfissuras preenchidas por material marrom amarelado.

\begin{tabular}{|ll|l|}
\hline $\begin{array}{l}\text { Processo } \\
\text { Observado }\end{array}$ & \multicolumn{1}{c|}{ Transformação Observada } & $\begin{array}{l}\text { Grau de } \\
\text { Intensidade }\end{array}$ \\
\hline & Muscovitização: Plagioclásio $\rightarrow$ Muscovita & Fraco a Moderado \\
& Epidotização: Plagioclásio $\rightarrow$ Epidoto & Moderado \\
& Carbonatização: Plagioclásio $\rightarrow$ Carbonato & Fraco a Moderado \\
& Serpentinização: Piroxênio $\rightarrow$ Serpentina & Fraco a Moderado \\
\hline
\end{tabular}




\section{Microscopia amostra (11)}

Rocha constituída basicamente por ortoclásio, plagioclásio, biotita e piroxênio como minerais essenciais, minerais opacos como acessórios e argilominerais como produtos de alteração secundária.

A rocha é composta quase que exclusivamente por ortoclásio (feldspato alcalino). O plagioclásio ocorre em grãos pouco visíveis, em geral são incolores não apresentando mais geminação. Muscovita, carbonato e sericita aparecem como subproduto de alteração parcial (sausuritização) do plagioclásio. Chama-se atenção para a grande quantidade de minerais opacos formados ao redor dos grãos de biotita e dispersos em toda a rocha.

As fases secundárias são compostas por caulinita e sericita que são produtos da alteração do ortoclásio e plagioclásio ocorrendo por toda a matriz da rocha. A rocha foi substituída quase que totalmente por minerais secundários, fruto da alteração ocorrida, restando apenas pseudomorfos, óxidos e/ou hidróxidos preenchendo suas fraturas. Os aspectos texturais (desbotado) sugerem que a alteração é hidrotermal de alta intensidade.

\begin{tabular}{|l|l|l|}
\hline $\begin{array}{l}\text { Processo } \\
\text { Observado }\end{array}$ & \multicolumn{1}{c|}{ Transformação Observada } & Grau de Intensidade \\
\hline & $\begin{array}{c}\text { Sericitização: Plagioclásio } \rightarrow \text { sericita } \\
\text { Ortoclásio } \rightarrow \text { sericita }\end{array}$ & $\begin{array}{l}\text { Moderado a intenso } \\
\text { Moderado a intenso }\end{array}$ \\
Hidrotermal & Caulinização: Ortoclásio $\rightarrow$ caulinita & Moderado a intenso \\
& Carbonatização: Plagioclásio $\rightarrow$ carbonato & Moderado \\
\hline
\end{tabular}




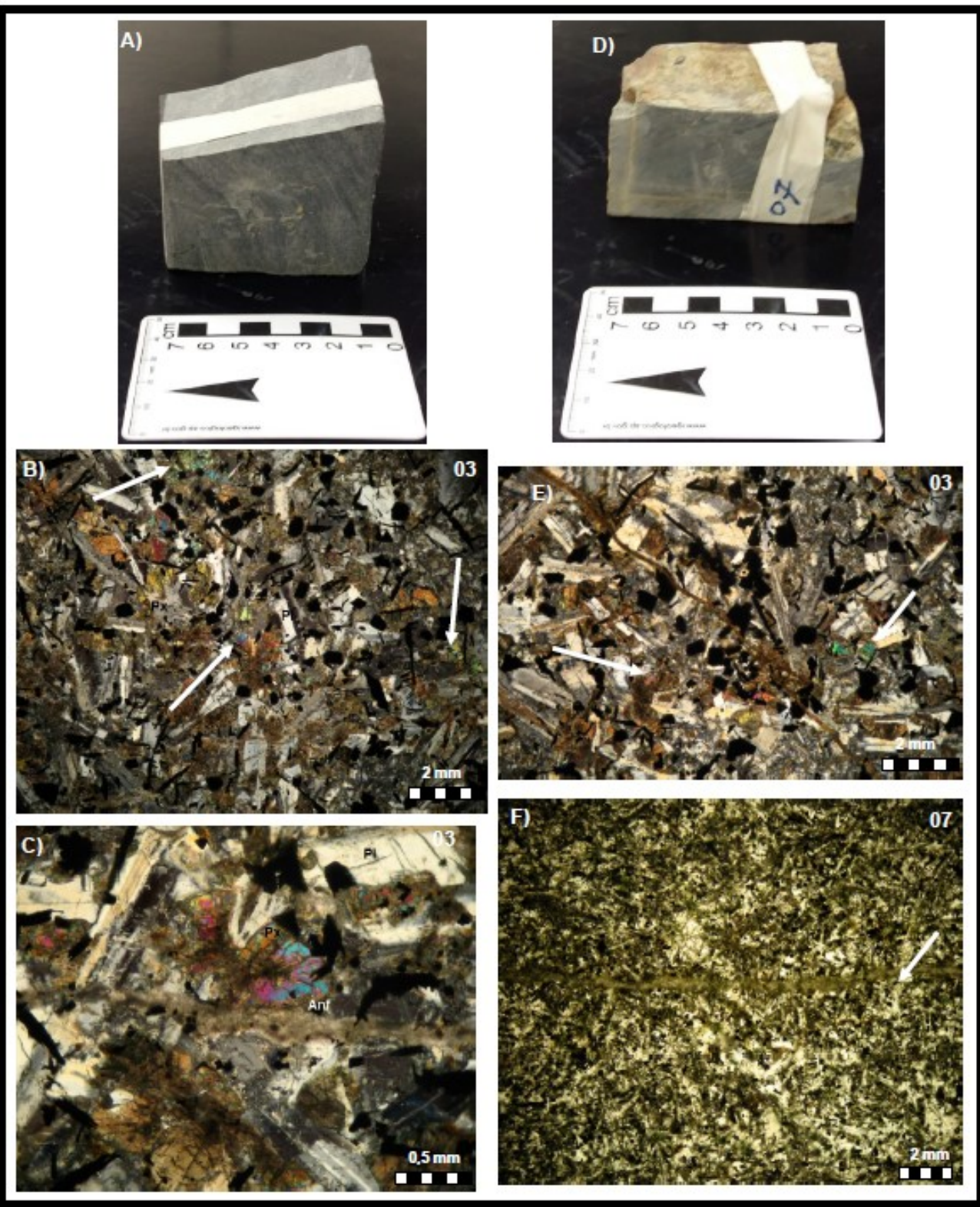

FIGURA 12 - Fotomicrografias das amostras 03 e 07. a) Aspecto macroscópico do Litotipo 03 (basalto); b) aspecto geral da textura subofítica, onde grãos de piroxênio por vezes estão substituídos por hornblenda (uralitização), luz polarizada; c) substituição de piroxênio por hornblenda junto com geração de fases minerais oxidadas e microfratura preenchida por material amorfo, ambos são frutos do resíduo da alteração hidrotermal, luz polarizada; d) aspecto macroscópico do litotipo 07 ; e) grãos de piroxênio alterados e microfissura cortando os minerais, luz polarizada; f) microfissura preenchida por material amorfo, grãos de piroxênio serpentinizados e hornblenda cloritizada, luz polarizada, litotipo 07. Legenda: Px: piroxênio; Pl: plagioclásio; Anf: Anfibólio. 

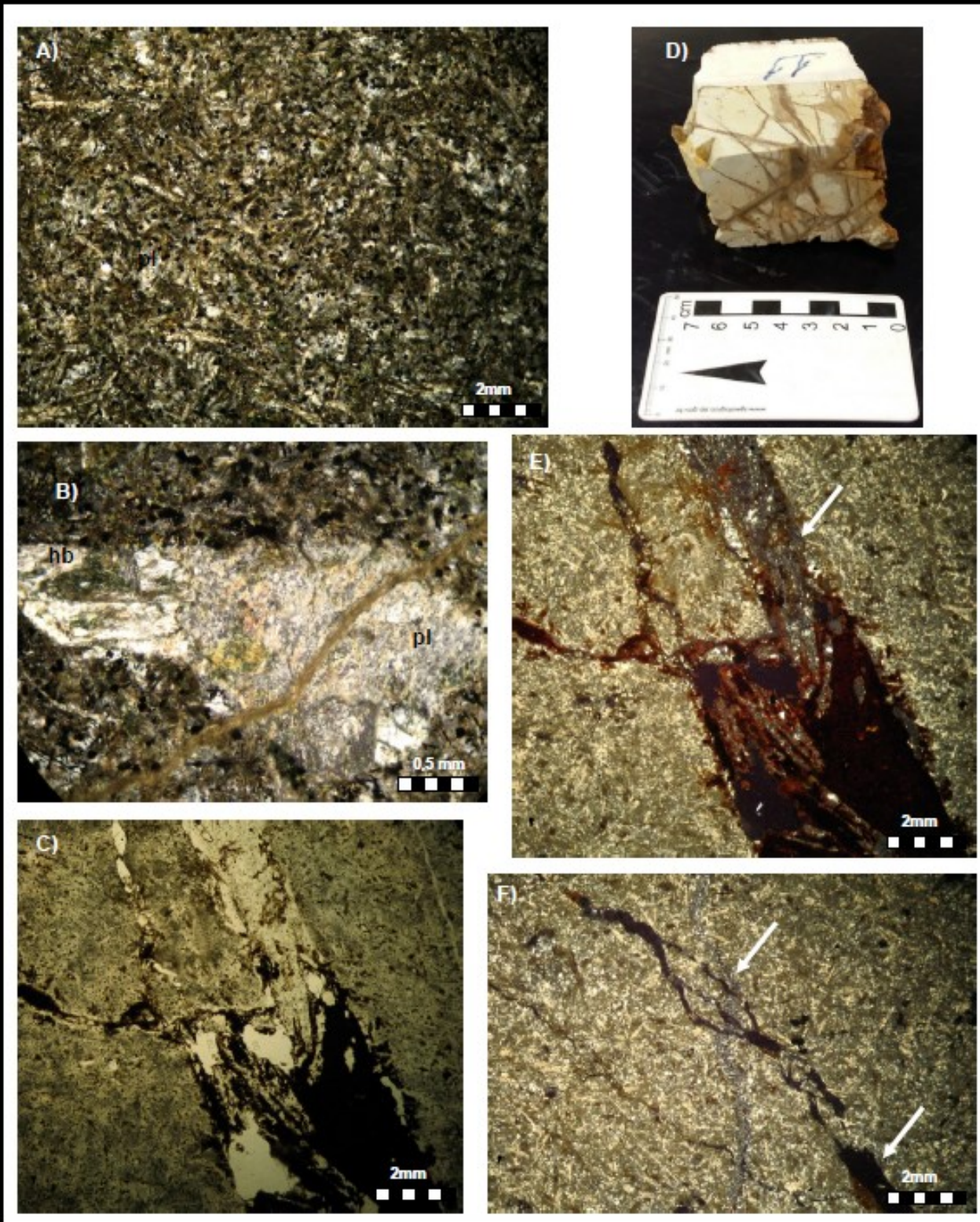

FIGURA 13 - Fotomicrografias da amostra 07 e 11. a) grande quantidade de óxidos, plagioclásio alterado e hornblenda cloritizada (amostra 07), luz polarizada; b) fenocristal de plagioclásio intensamente sausuritizado, sendo substituído por epidoto, sericita e calcita, cortado por microfissura preenchida por material amorfo, luz polarizada; c) aspecto da textura granular com matriz totalmente transformada, sugerindo alta intensidade hidrotermal do litotipo 11, luz natural; d) aspecto macroscópico do lito-tipo 11; e) fratura preenchida por material marrom avermelhado e silica, luz polarizada; f) substituição quase total da paragênese primária, fratura preenchida por sílica e material amorfo, luz polarizada. Legenda: Pl: plagioclásio; hb: hornblenda. 


\subsubsection{CONJUNTO 03 - Amostras Unidade Ortoderivada}

Três amostras foram examinadas para este litotipo e de acordo com o aspecto tátil visual foram classificadas como rocha não alterada (21), a rocha medianamente alterada (20) e rocha alterada (22). Abaixo segue a descrição detalhada das características das amostras.

\section{\#Granodiorito gnaisse 21}

\section{Microscopia}

Rocha constituídabasicamentepor plagioclásio, microclina, quartzo e biotita como minerais essenciais, apatita, zircão, granada e minerais opacos como acessórios principais, carbonato, muscovita, sericita e argilominerais como produtos de alteração secundária.

O plagioclásio apresenta perfeita geminação (lei da albita). Alguns poucos grãos estão transformados (sausuritização) tanto no núcleo quanto nas bordas, porém à grande maioria mostram-se límpidos e não alterados. Raras são às vezes em que o grão se mostra substituído por muscovita e epidoto. Podem-se perceber duas fases de cristalização do plagioclásio, onde a primeira se mostra com grãos grossos, bem formados, límpidos com geminação bem marcada. Numa segunda fase, os grãos se mostram com textura granular, alguns inclusos em cristais de microclina, evidenciando uma geração tardia de crescimento, talvez durante o processo de deformação. A microclina com geminação bem formada do padrão "Tartan", apresentam contornos hidioblásticosa xenoblásticos. Alguns grãos se mostram fraturados e recristalizados sendo preenchidos por material carbonático e sericítico. A biotita mostra-se pouco transformada por fases de crescimento tardio por atuação de processos hidrotermais como muscovita, clorita e minerais opacos. Algumas predominam o padrão "birds eyes" que significa entrada de água nos retículos de sua estrutura.

As fases secundárias foram identificadas pelas raras substituições da biotita por muscovita (muscovitização) e clorita (cloritização), processos de sausuritização e seritização ocorrem nos núcleos e microfissuras de poucos grãos de plagioclásio. 


\section{\#Granodiorito gnaisse 20 e 22}

\section{Microscopia}

A rocha apresenta textura idioblástica e sua foliação não é tão marcante, sendo definida e orientada pelos grãos de biotita e plagioclásio. Possui textura lepido-granoblástica, por vezes ocorrendo contatos poligonizados, chegando a observar pontos tríplices e texturais em mosaico. Aspectos texturais de mirmequita e pertita também foram encontrados.

Os minerais que compõem a trama mineralógica mostram composição variando de granodiorítica a tonalítica.

O plagioclásio apresenta perfeita geminação polissintética (lei da albita). Alguns grãos estão sausuritizados tanto no núcleo quanto em suas bordas em contato com microclina e quartzo. Alguns grãos mostram inclusões em grande parte por quartzo e biotita. Por vezes os grãos de plagioclásio estão micro fissurados sendo substituídos por muscovita, sericita e calcita. A microclina apresenta geminação incipiente ou mal formada do padrão tipo "Tartan". Alguns grãos se mostram fraturados sendo preenchidos por material carbonático. A biotita mostra-se em geral transformada para muscovita e clorita, algumas predominam padrão "birds eyes" que significa entrada de água nos retículos de sua estrutura. As fases acessórias formadas por apatita, zircão, granada e minerais opacos ocorrem em volume restrito dispersas pela matriz da rocha.

As fases secundárias foram identificadas pela substituição da biotita por muscovita (muscovitização) e clorita (cloritização). Grãos de plagioclásio são substituídos por grãos de muscovita, em geral em seus planos de geminação e clivagens, por ação hidrotermal. Processos de sausuritização e seritização foram observados nas microfissuras dos grãos de plagioclásio. Carbonato foi observado tanto em grãos de plagioclásio quanto em grãos de microclina normalmente preenchendo as microfraturas. Em geral os produtos de alteração da microclina estão restritos as microfissuras e as inclusões, onde os grãos apresentam total limpidez, diferentemente dos grãos de plagioclásio. 


\begin{tabular}{|c|c|c|c|}
\hline $\begin{array}{l}\text { Processo } \\
\text { Observado }\end{array}$ & \multicolumn{2}{|c|}{ Transformação Observada } & $\begin{array}{l}\text { Grau de } \\
\text { Intensidade }\end{array}$ \\
\hline Hidrotermal & $\begin{array}{l}\text { Cloritização: } \\
\text { Muscovitização: } \\
\text { Sericitização: } \\
\text { Carbonatização: }\end{array}$ & $\begin{array}{l}\text { Biotita } \rightarrow \text { Clorita } \\
\text { Plagioclásio } \rightarrow \text { muscovita } \\
\text { Biotita } \rightarrow \text { muscovita } \\
\text { Plagioclásio } \rightarrow \text { sericita } \\
\text { Plagioclásio } \rightarrow \text { carbonato } \\
\text { Microclina } \rightarrow \text { carbonato }\end{array}$ & $\begin{array}{l}\text { Fraco } \\
\text { Fraco } \\
\text { Fraco } \\
\text { Fraco } \\
\text { Fraco } \\
\text { Fraco }\end{array}$ \\
\hline $\begin{array}{l}\text { Retro- } \\
\text { metamorfismo }\end{array}$ & $\begin{array}{l}\text { Biotita } \rightarrow \\
\text { Plagioclásio } \rightarrow \\
\text { Plagioclásio } \rightarrow \\
\text { Biotita } \rightarrow\end{array}$ & $\begin{array}{l}\text { Muscovita } \\
\text { Sericita } \\
\text { Muscovita } \\
\text { Clorita }\end{array}$ & $\begin{array}{l}\text { Fraco } \\
\text { Fraco } \\
\text { Fraco } \\
\text { Fraco }\end{array}$ \\
\hline
\end{tabular}




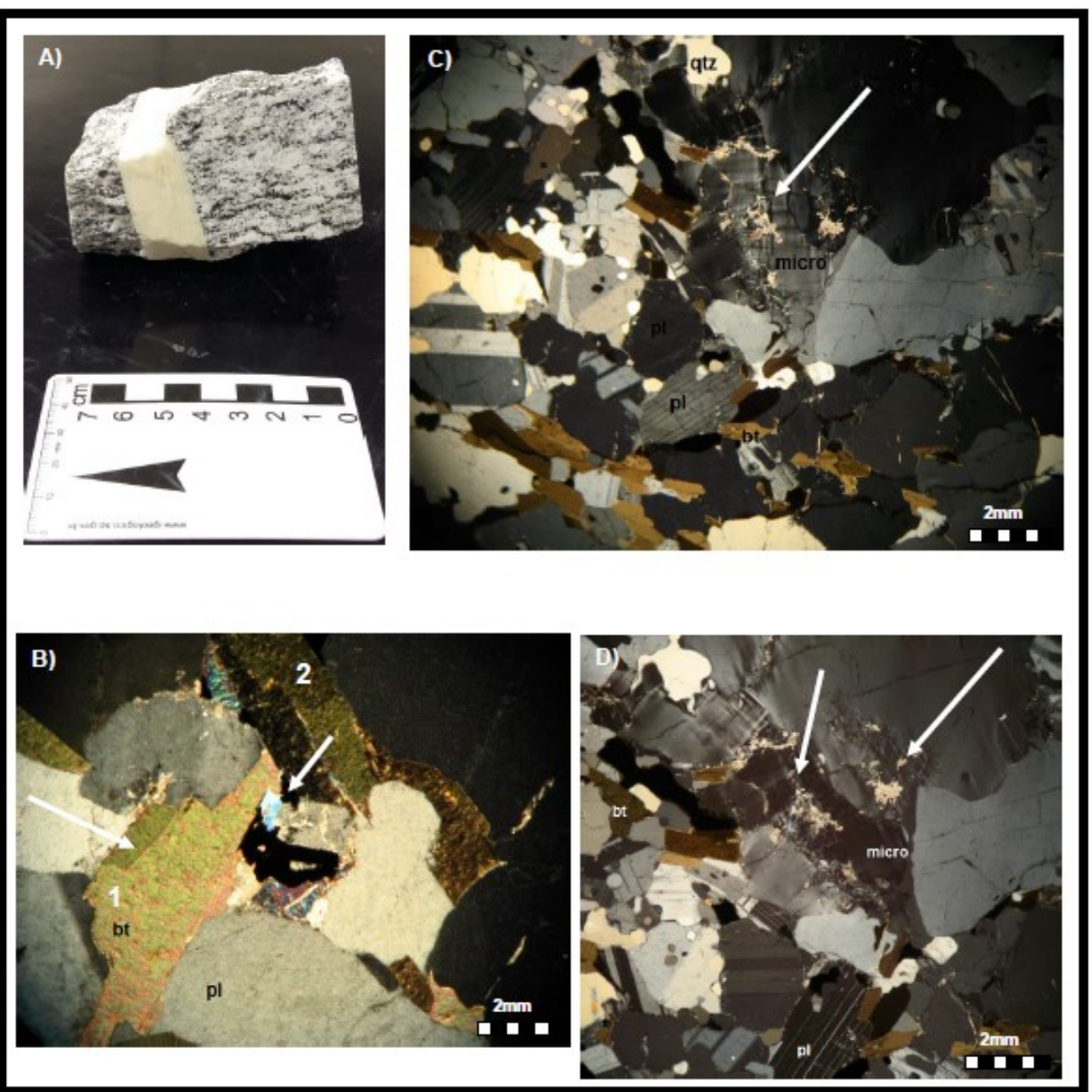

FIGURA 14 - Fotomicrografias da amostra 21. a) aspecto macroscópico do litotipo 21 ; b) observar os estágios de alteração da biotita: 1) grão de biotita levemente alterado para clorita e muscovita; 2) grão com padrão "birds eyes" marcando a transformação; grãos de plagioclásio inalterados, luz polarizada; c) aspecto geral da textura da rocha, vale ressaltar o preenchimento por material carbonático nas fraturas do grão de microclina, luz polarizada; d) grãos de microclina preenchidos por material carbonático, luz polarizada. Legenda: $\mathrm{Pl}$ : plagioclásio; bt: biotita; micro: microclina. 


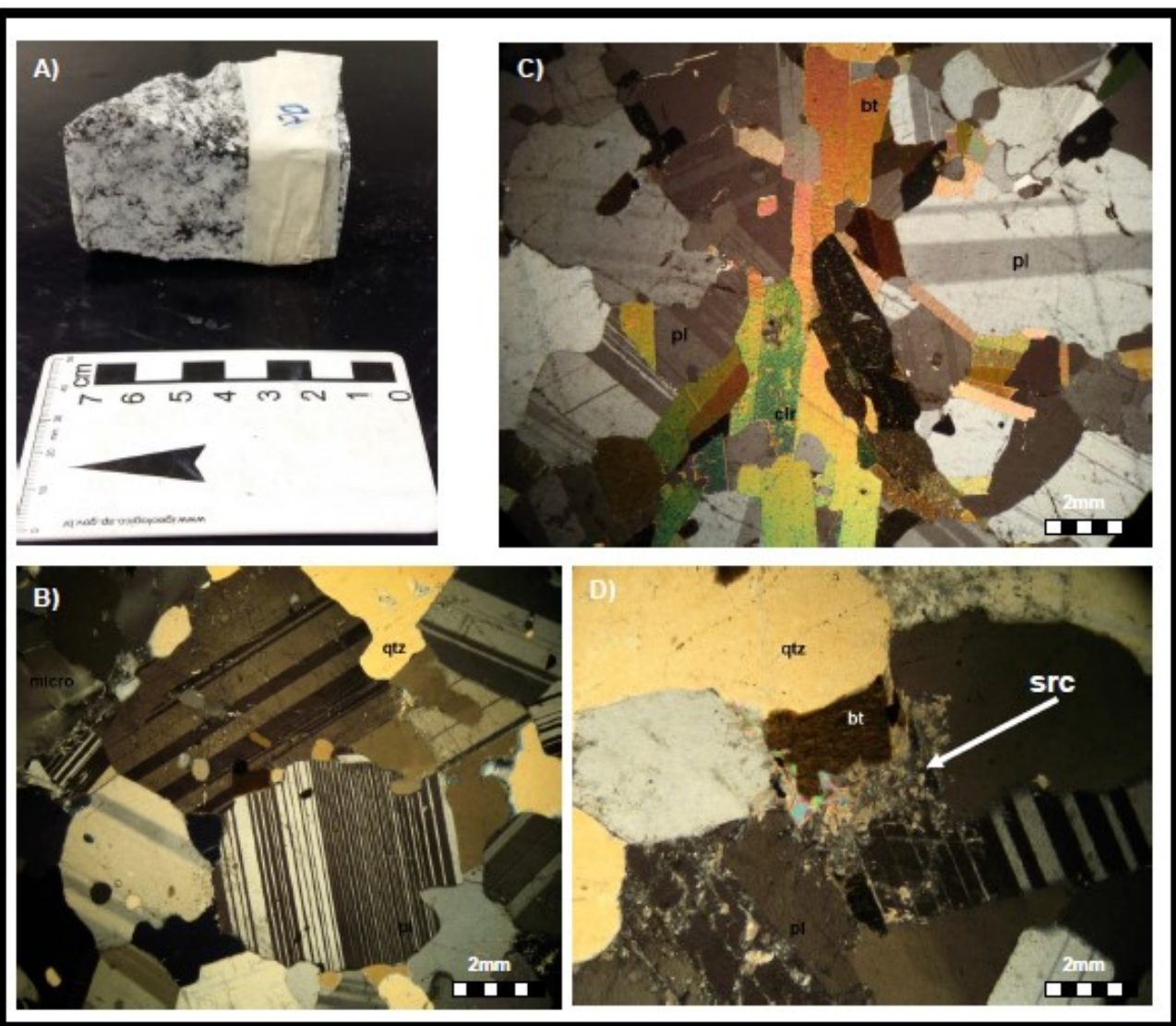

FIGURA 15 - Fotomicrografias da amostra 20. a) aspecto macroscópico do litotipo 20; b) aspecto geral da textura inequigranular, luz polarizada; c) grãos de biotita levemente transformados para clorita com padrão "birds eyes", luz polarizada; d) grãos de plagioclásio sausuritizados gerando sericita, epidoto e carbonato, luz polarizada. Legenda: Pl: plagioclásio; bt: biotita; micro: microclina; qtz: quartzo; clr: clorita. 


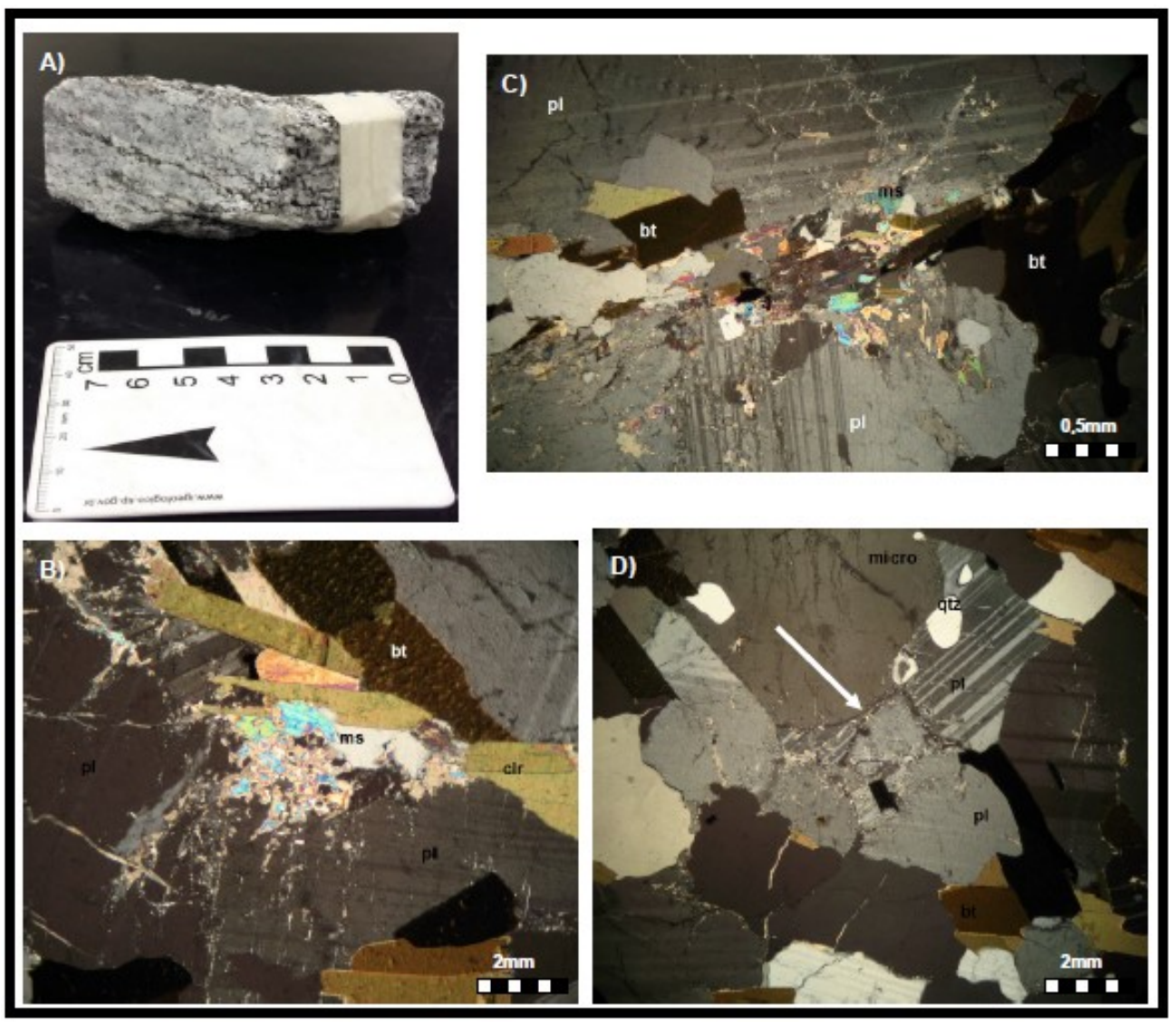

FIGURA 16 - Fotomicrografias da amostra 22. a) aspecto macroscópico do litotipo 22; b) megacristal de plagioclásio sausuritizado, grão de biotita se transformando em muscovita e clorita, biotita com padrão "birds eyes", luz polarizada; c) grãos de biotita transformados parcialmente em clorita e muscovita, grãos de plagioclásio levemente sausuritizados, luz polarizada; d) observar os contatos tríplices entre os grãos de plagioclásio, luz polarizada. Legenda: $\mathrm{Pl}$ : plagioclásio; bt: biotita; micro: microclina; qtz: quartzo; clr: clorita; ms: muscovita. 


\subsubsection{CONJUNTO 04 - Amostras Unidade Kinzigitica}

Três amostras foram examinadas para litotipo e de acordo com o aspecto tátil visual foram classificadas como rocha não alterada (01), rocha medianamente alterada (23) e rocha alterada (25). Abaixo segue a descrição detalhada das características das amostras.

\section{\#Granada biotita gnaisse 01}

\section{Microscopia}

A rocha é composta plagioclásio, quartzo, biotita e microclina, como minerais essenciais, apatita, zircão, granada e minerais opacos como acessórios principais, carbonato e muscovita como produtos de alteração secundária.

O plagioclásio em geral tem hábito prismático a granular com caráter poiquiloblástico com várias inclusões de apatita, quartzo, biotita, zircão e granada. A microclina apresenta hábito tabular a granular, textura hipidioblástica, alguns grãos possuem ex-solução de plagioclásio (pertita) e textura poquilitica com inclusões de quartzo, biotita e apatita. Por vezes se mostram intensamente fraturados no plano de foliação. O quartzo apresenta grãos hipidioblásticos a xenoblásticos em geral ocupando os espaços intersticiais e inclusos dentro de cristais de plagioclásio e microclina. A biotita ocorre emgeral pouco transformada com inclusões de apatita, quartzo e zircão. Os minerais opacos ocorrem nas bordas e nas clivagens da biotita e em grãos individualizados.

As fases secundárias foram identificadas pelas raras substituições da biotita por muscovita, provavelmente causadas por retrometamorfismo. Raros são os grãos de microclina e plagioclásio preenchido por carbonatos.

\section{\#Granada biotita gnaisse 23}

\section{Microscopia}

A rocha é composta por plagioclásio, quartzo, biotita e microclina como minerais essenciais, apatita, zircão, minerais opacos e granada, como acessórios principais, carbonato, muscovita, epidoto e argilominerais como produtos de alteração secundária. 
Os grãos de plagioclásio se mostram límpidos fora do plano de foliação, pouco alterados, com inclusões de apatita, quartzo e biotita. Já no plano de foliação eles estão fraturados, apresentando por vezes cores de interferência alta e zonada, provavelmente devido à ação da deformação/ ou cisalhamento sofrido. As substituições mineralógicas provocadas por ação hidrotermais mais visíveis são o crescimento de carbonato (sausuritização), muscovita (muscovitização) e epidoto (epidotização). A microclina ocorre em cristais muito fraturados, geminados segundo padrão "Tartan”, mas com geminação perdida em diversos grãos, por vezes fraturada devido a processos de intensa deformação e metamorfismo. As substituições mais visíveis nos grãos de biotita são o crescimento de muscovita nos seus planos de clivagens e em suas bordas. Os minerais opacos por vezes aparecem como produto de alteração hidrotermal da biotita gerando óxidos de ferro nos seus planos de clivagens e bordas.

As fases secundárias foram identificadas pelas raras substituições da biotita por muscovita que surge por ação hidrotermal. Raras vezes aparecem grãos de microclina e plagioclásio preenchido por carbonatos. A transformação de plagioclásio para epidoto ocorre em grãos fraturados, com cor de interferência amarelada. É possível identificar grãos de plagioclásio e microclina microfraturados possivelmente causados por planos que controlam estruturalmente as rochas da região do túnel, realçando a presença de zonas de cisalhamento nessa região.

\begin{tabular}{|c|c|c|}
\hline $\begin{array}{l}\text { Processo } \\
\text { Observado }\end{array}$ & Transformação Observada & $\begin{array}{l}\text { Grau de } \\
\text { Intensidade }\end{array}$ \\
\hline \multirow{5}{*}{ Hidrotermal } & $\begin{aligned} \text { Muscovitização: } & \text { Plagioclásio } \rightarrow \text { muscovita } \\
& \text { Biotita } \rightarrow \text { muscovita }\end{aligned}$ & $\begin{array}{l}\text { Fraco } \\
\text { Fraco }\end{array}$ \\
\hline & Epidotização: $\quad$ Plagioclásio $\rightarrow$ epidoto & Moderado \\
\hline & Plagioclásio $\rightarrow$ sericita & Fraco a Moderado \\
\hline & Carbonatização: Plagioclásio $\rightarrow$ carbonato & Moderado \\
\hline & Microclina $\rightarrow$ carbonato (preenchimento) & Fraco \\
\hline $\begin{array}{l}\text { Retro- } \\
\text { metamorfismo }\end{array}$ & $\begin{array}{lll}\text { Biotita } \rightarrow & \text { Muscovita } \\
\text { Plagioclásio } \rightarrow & \text { Sericita } \\
\text { Plagioclásio } \rightarrow & \text { Muscovita }\end{array}$ & $\begin{array}{l}\text { Fraco } \\
\text { Fraco a moderado } \\
\text { Fraco }\end{array}$ \\
\hline
\end{tabular}




\section{\#Granada biotita gnaisse 25}

\section{Microscopia}

A rocha apresenta um forte padrão de deformação e orientação de minerais planares, marcado por truncamentos do plano de foliação e embricamento de grãos. Sua composição é dada por plagioclásio, microclina, quartzoe biotita como minerais essenciais, apatita, zircão, granada e minerais opacos como acessórios principais, carbonato, muscovita, clorita, epidoto e argilominerais como produtos de alteração secundária.

O plagioclásio ocorre sob a forma de grãos xenoblásticos com rara preservação da geminação devido ao intenso processo de alteração de seus grãos. À grande maioria dos grãos estão sausuritizados em graus variados. Ocorrem substituições por muscovita, sericita e epidoto, por vezes substituindo totalmente o cristal restando apenas pseudomorfos. A microclina ocorre em cristais muito fraturados, não sendo possível identificar com clareza sua geminação, sendo ela ausente ou mal formada, principalmente os grãos xenoblásticos, por vezes fraturados devido a processos de intensa deformação. A biotita possui hábito tabular e "birds eyes" característico, com inúmeras inclusões de minerais opacos, sendo fruto do processo de alteração hidrotermal. Sua associação com a muscovita é evidente, sendo esta observada comumente crescendo a partir das clivagens e de suas bordas. Observa-se em grande parte o truncamento da foliação, com cristais de biotita sobrepostos. Os minerais opacos encontram-se associados principalmente a biotita, apresentando-se com hábito granular e tabular, contatos hipioblásticos a xenoblásticos.

As fases secundárias foram identificadas a partir de processos de substituição mineral no estado sólido, onde a fase predominante são as micas brancas (muscovita e sericita). Biotita sendo intensamente substituída por muscovita e clorita. Os grãos de plagioclásio alterando-se tanto para muscovita quanto para sericita, além de epidoto. $\mathrm{O}$ carbonato ocorre pelo processo de sausuritização, por intensa transformação do cristal de plagioclásio gerando grãos pseudomorfos e preenchendo microfraturas nos grãos de microclina. É possível identificar fases de intensa sausuritização do plagioclásio gerando fases de epidoto, sericita e argilominerais. 
A observação microestrutural mostrou um intenso controle imposto pela foliação, assim como a presença de cisalhamentos que induziram a penetração de fluídos que atuaram nos processos de transformação, tanto hidrotermal, quanto retrometamórficos.

\begin{tabular}{|c|c|c|c|}
\hline $\begin{array}{l}\text { Processo } \\
\text { Observado }\end{array}$ & \multicolumn{2}{|c|}{ Transformação Observada } & Grau de Intensidade \\
\hline Hidrotermal & $\begin{array}{l}\text { Muscovitização: } \\
\text { Sericitização: } \\
\text { Epidotização: } \\
\text { Carbonatização: } \\
\text { Cloritização: }\end{array}$ & $\begin{array}{l}\text { Plagioclásio } \rightarrow \text { Muscovita } \\
\text { Biotita } \rightarrow \text { Muscovita } \\
\text { Plagioclásio } \rightarrow \text { Sericita } \\
\text { Plagioclásio } \rightarrow \text { Epidoto } \\
\text { Plagioclásio } \rightarrow \text { Carbonato } \\
\text { Microclina } \rightarrow \text { Carbonato } \\
\text { Biotita } \rightarrow \text { Clorita }\end{array}$ & $\begin{array}{l}\text { Moderada } \\
\text { Intenso } \\
\text { Intenso } \\
\text { Moderada } \\
\text { Moderada a intenso } \\
\text { Moderada } \\
\text { Fraco a Moderada }\end{array}$ \\
\hline $\begin{array}{l}\text { Retro- } \\
\text { metamorfismo }\end{array}$ & $\begin{array}{l}\text { Biotita } \rightarrow \\
\text { Plagioclásio } \rightarrow \\
\text { Plagioclásio } \rightarrow \\
\text { Biotita } \rightarrow\end{array}$ & $\begin{array}{l}\text { Muscovita } \\
\text { Sericita } \\
\text { Muscovita } \\
\text { Clorita }\end{array}$ & $\begin{array}{l}\text { Intenso } \\
\text { Moderado } \\
\text { Moderada } \\
\text { Moderada }\end{array}$ \\
\hline
\end{tabular}



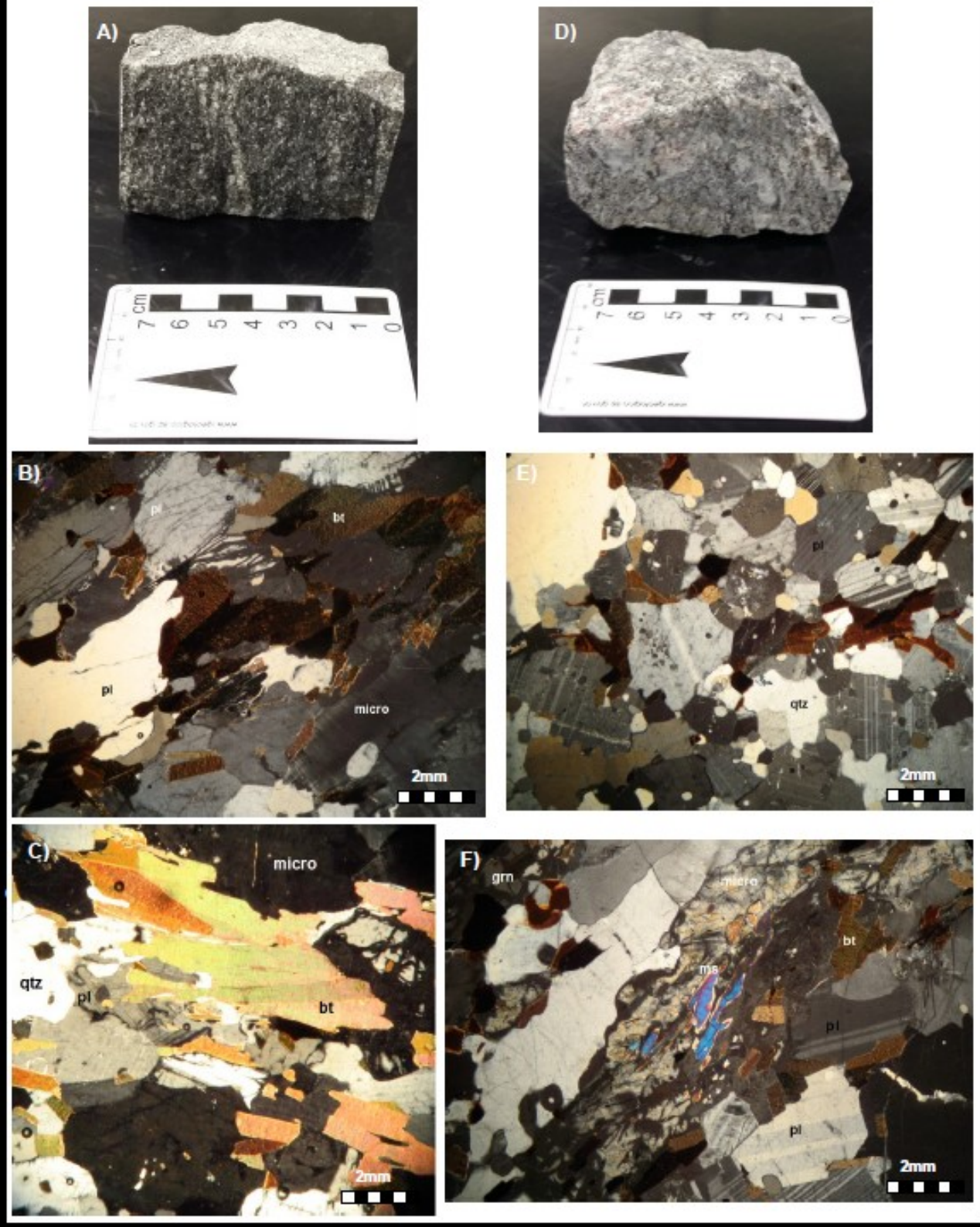

FIGURA 17- Fotomicrografias das amostras 01 e 23. a) aspecto macroscópico do litotipo 01 (rocha sã); b) biotita com padrão "birds eyes", feldspatos inalterados, luz polarizada; c) grão de biotita levemente alterado para clorita, luz polarizada; d) aspecto macroscópico do litotipo 23 (rocha medianamente alterada); e) aspecto da textura granoblástica com minerais inalterados; f) forte padrão de deformação e orientação de minerais planares, com minerais recristalizados e fraturados, luz polarizada. Legenda: pl: plagioclásio; ms: muscovita; hb/anf: hornblenda ou anfibólio; bt: biotita; micro: microclina; grn: granada. 


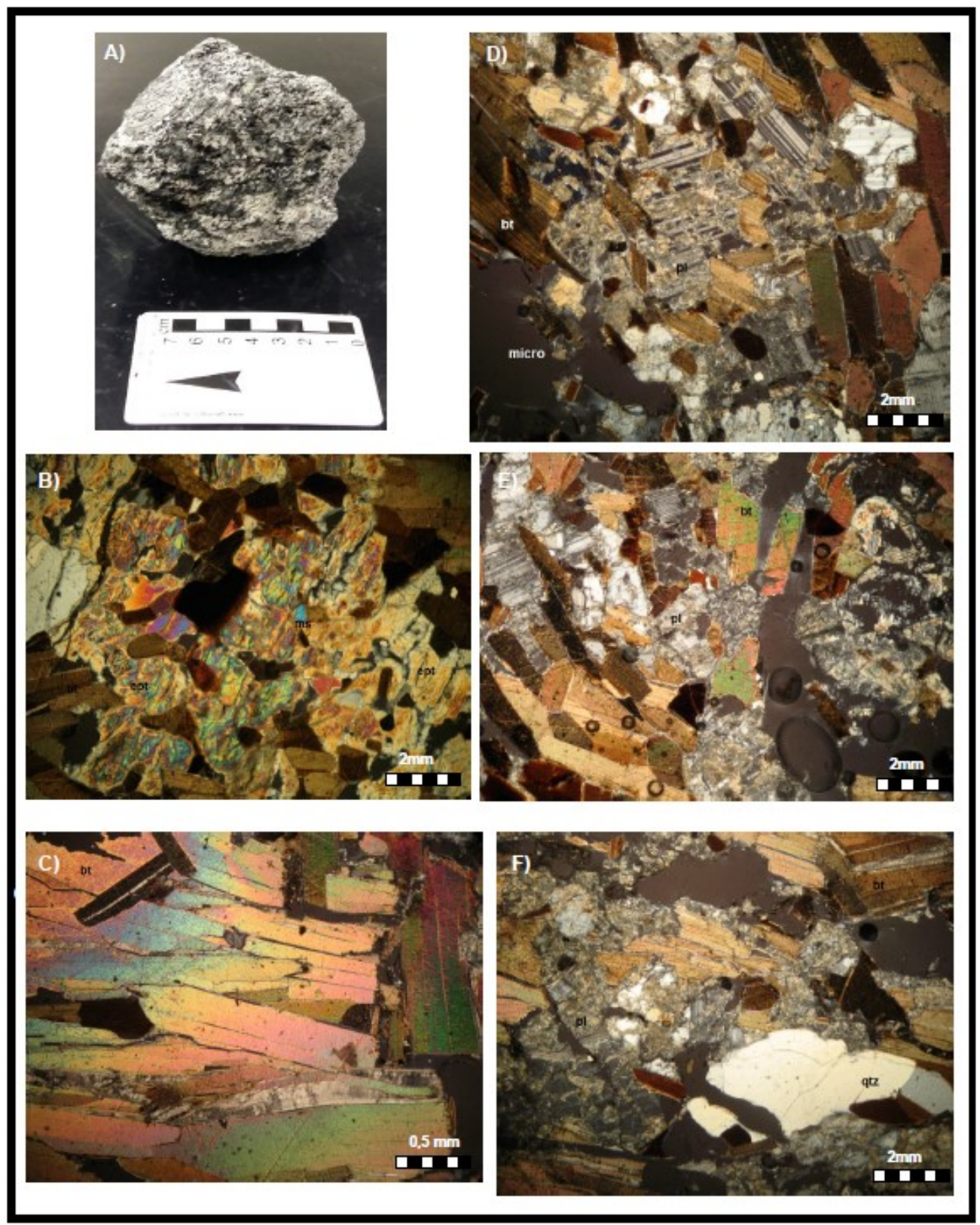

FIGURA 18 - Fotomicrografias da amostra 25. a) aspecto macroscópico do litotipo 25 (rocha alterada); b) forte hidrotermalização que atinge o plagioclásio (sausuritização), gerando epidoto, sericita e muscovita, luz polarizada; c) grãos pseudomorfos de muscovita formados pela substituição da biotita devido ao processo matamórfico ou hidrotermal, luz polarizada; d) grãos de biotita fraturados e plagioclásio intensamente sausuritizado, além de grão de biotita cloritizado, luz polarizada; e) grãos de plagioclásio fortemente alterados para saussurita, grãos de biotita cloritizados; f) plagioclásio sofrendo intenso processo de saussuritização gerando calcita, epidoto e sericita, grãos de biotita imbricados e fraturados evidenciando um intenso controle imposto pela foliação, luz polarizada. 
Legenda: pl: plagioclásio; ms: muscovita; bt: biotita; micro: microclina; ept: epidoto.

\subsubsection{CONJUNTO 05 - Amostras Unidade Granito Pedra Branca e Unidade Kinzigitica}

\section{\#Anfibolito 04}

\section{Microscopia}

A rocha é composta por hornblenda, plagioclásio, piroxênio, quartzo e biotita como minerais essenciais, apatita, zircão e minerais opacos como acessórios principais, carbonato, muscovita, clorita, epidoto e argilominerais como produtos de alteração secundária.

A hornblenda esta parcialmente substituída por biotita e em geral transformada em clorita, epidoto e raramente minerais opacos, sugerindo processos de caráter hidrotermal e retrometamórfico. O plagioclásio ocorre com rara preservação da geminação devido ao intenso processo de alteração e deformação de seus grãos. À maior parte dos seus grãos estão totalmente fraturados e sausuritizados em variados graus. Ocorrem substituições por muscovita, sericita e epidoto, por vezes substituindo totalmente o cristal restando apenas pseudomorfos. Parte dos grãos de piroxênio estão transformados em hornblenda, serpentina (serpentinização) e em alguns casos ocorre crescimento de biotita em suas bordas. A biotita ocorre em grãos alterados para clorita e muscovita. Sua associação com a muscovita é evidente, sendo esta observada comumente crescendo a partir das clivagens e de suas bordas, gerando na maioria das vezes grãos pseudomorfos. Os minerais opacos são raros e encontram-se associados principalmente a biotita, apresentando-se com hábito granular e granulometria fina.

As fases secundárias foram identificadas a partir de processos de substituição mineral no estado sólido, onde a fase predominante é a mica branca (muscovita e sericita). Os grãos de muscovita aparecem pela substituição do plagioclásio e biotita gerando grãos pseudomorfos. A transformação de biotita e hornblenda em clorita e plagioclásio sausuritizado gerando muscovita, sericita, 
epidoto e carbonato ocorre de forma intensa, perfazendo grande parte das transformações observadas.

\begin{tabular}{|c|c|c|}
\hline $\begin{array}{l}\text { Processo } \\
\text { Observado }\end{array}$ & Transformação Observada & Grau de Intensidade \\
\hline \multirow{6}{*}{ Hidrotermal } & $\begin{aligned} \text { Muscovitização: } & \text { Plagioclásio } \rightarrow \text { Muscovita } \\
& \text { Biotita } \rightarrow \text { Muscovita }\end{aligned}$ & $\begin{array}{l}\text { Moderada } \\
\text { Moderado }\end{array}$ \\
\hline & Sericitização: $\quad$ Plagioclásio $\rightarrow$ Sericita & Intenso \\
\hline & Epidotização: $\quad$ Plagioclásio $\rightarrow$ Epidoto & Moderada \\
\hline & Carbonatização: Plagioclásio $\rightarrow$ Carbonato & Moderada \\
\hline & $\begin{array}{ll}\text { Cloritização: } & \text { Biotita } \rightarrow \text { Clorita } \\
& \text { Hornblenda } \rightarrow \text { Clorita }\end{array}$ & $\begin{array}{l}\text { Moderada a intenso } \\
\text { Moderada a intenso }\end{array}$ \\
\hline & Serpentinização: Piroxênio $\rightarrow$ Serpentina & Moderado \\
\hline \multirow{4}{*}{$\begin{array}{l}\text { Retro- } \\
\text { metamorfismo }\end{array}$} & Biotita $\quad \rightarrow \quad$ Muscovita & Moderado \\
\hline & Plagioclásio $\rightarrow$ Sericita & Moderada \\
\hline & Plagioclásio $\rightarrow$ Muscovita & Moderada \\
\hline & Biotita $\quad \rightarrow \quad$ Clorita & Moderado \\
\hline
\end{tabular}

\#Granito 08

\section{Microscopia}

De acordo com a análise ao microscópio a rocha é composta por microclina, plagioclásio, biotita, quartzo como minerais essenciais, apatita, zircão, titanita e minerais opacos como minerais acessórios principais, carbonato, muscovita e argilominerais como produtos de alteração secundária, induzidos por ação hidrotermal e/ou deformação dinâmica.

O plagioclásio apresenta duas fases de cristalização, uma com grãos bem formados, de habito tabular a colunar, com granulação grossa, possuindo contatos retilíneos e não alterados, rico em inclusões, em geral, alterado por processos de transformação hidrotermal que não afetaram o plagioclásio. A segunda fase apresenta grãos subédricos a anédricos, com granulometría variando de fina a média, sausuritizados tanto no centro quanto em suas bordas, com inclusões de 
biotita alterada, zircão, apatita e quartzo. Foram observados grãos com texturas poiquilíticas onde se podem notar inclusões de quartzo e biotita.

A biotita mostra-se alterada, principalmente por clorita e muscovita. Podem-se notar vários grãos totalmente substituídos gerando grãos pseudomorfos. Os grãos de microclina em geral apresentam-se levemente microfraturados, sendo preenchidos por material sericítico e carbonático.

As fases secundárias formadas por processos de transformação mineral surgem a partir das raras transformações da biotita em muscovita e clorita, que crescem preferencialmente nos seus planos de clivagens. Algumas microfissuras nos grãos de microclina favorecem a percolação de fluídos alterando-os em poucos casos para sericita e carbonato. Poucos grãos de plagioclásio estão transformados por sausuritização. Portanto para a amostra estudada pode ser afirmado que se trata de um processo de baixa intensidade hidrotermal, visto que poucos grãos aparecem transformados mineralogicamente.

\begin{tabular}{|lr|c|}
\hline $\begin{array}{l}\text { Processo } \\
\text { Observado }\end{array}$ & \multicolumn{1}{c|}{ Transformação Observada } & Grau de Intensidade \\
\hline & Muscovitização: Plagioclásio $\rightarrow$ Muscovita \\
Biotita $\rightarrow$ Muscovita & Fraco \\
Fidrotermal & Fraco \\
& $\begin{array}{c}\text { Sericitização: } \quad \text { Plagioclásio } \rightarrow \text { Sericita } \\
\text { Carbonatização: Plagioclásio } \rightarrow \text { Carbonato }\end{array}$ & Fraco a moderado \\
& Microclina $\rightarrow$ carbonato (preenchimento) & Fraco \\
& Cloritização: Biotita $\rightarrow$ Clorita & Fraco \\
& & \\
\hline
\end{tabular}

\section{\# Biotita gnaisse 10}

\section{Microscopia}

A rocha apresenta um forte padrão de deformação e orientação de minerais planares, com minerais recristalizados e fraturados. Sua composição é dada por plagioclásio, quartzo, biotita, microclina como minerais essenciais, 
apatita, zircão e minerais opacos como acessórios principais, sericita, carbonato, muscovita, epidoto e argilominerais como produtos de alteração secundária.

O plagioclásio não apresenta geminação, devido ao intenso processo de alteração de seus grãos. Em geral os grãos estão totalmente sausuritizados, com inclusões de apatita, quartzo e biotita. Já no plano de foliação eles estão fraturados, apresentando por vezes cores de interferência alta e zonada, provavelmente devido à ação da alteração e deformação ou cisalhamento. As substituições mineralógicas provocadas por ação hidrotermais mais visíveis são o crescimento de carbonato (sausuritização), muscovita (muscovitização) e epidoto (epidotização). A microclina ocorre em cristais muito fraturados, de granulação fina $(<1 \mathrm{~mm})$, não apresenta geminação devido ao intenso processo de deformação, principalmente os grãos xenoblásticos. A biotita apresenta-se substituída por muscovita e minerais opacos tanto nos seus planos de clivagens quanto em suas bordas e parte de seus grãos estão transformados em clorita. Os minerais opacos por vezes aparecem como produto de alteração hidrotermal da biotita gerando óxidos de ferro nos seus planos de clivagens e bordas.

As fases secundárias foram identificadas pelas intensas substituições da biotita por muscovita que surge por ação hidrotermal e em parte por clorita. Grãos de plagioclásio intensamente sausuritizados e fraturados, levando ao aparecimento de fases de mica branca, carbonato e epidoto. Do ponto da análise microestrutural, são evidentes as ocorrências de planos de foliação determinados pelo arranjo planar de minerais máficos (biotita) e embricamento de grãos de plagioclásio e microclina. Há um intenso controle estrutural por parte da foliação e planos de cisalhamentos na percolação dos fluídos e consequentemente facilitando os processos de alteração.

\begin{tabular}{|lll|l|}
\hline $\begin{array}{l}\text { Processo } \\
\text { Observado }\end{array}$ & \multicolumn{2}{|c|}{ Transformação Observada } & Grau de Intensidade \\
\hline Muscovitização: & $\begin{array}{l}\text { Plagioclásio } \rightarrow \text { muscovita } \\
\text { Biotita } \rightarrow \text { muscovita }\end{array}$ & $\begin{array}{l}\text { Moderado } \\
\text { Intenso }\end{array}$ \\
& Epidotização: & Plagioclásio $\rightarrow$ Epidoto & Moderado \\
Hidrotermal & Sericitização: & $\begin{array}{l}\text { Plagioclásio } \rightarrow \text { sericita } \\
\text { Microclina } \rightarrow \text { sericita }\end{array}$ & $\begin{array}{l}\text { Moderado a intenso } \\
\text { Moderado a intenso }\end{array}$ \\
& Cloritização: & Biotita $\rightarrow$ Clorita & Fraco a moderado \\
\hline
\end{tabular}




\begin{tabular}{|l|l|l|}
\hline $\begin{array}{l}\text { Carbonatização: Plagioclásio } \rightarrow \text { carbonato } \\
\text { Microclina } \rightarrow \text { carbonato (preenchimento) }\end{array}$ & $\begin{array}{l}\text { Moderado a intenso } \\
\text { Moderado }\end{array}$ \\
\hline \multirow{2}{*}{$\begin{array}{l}\text { Retro- } \\
\text { metamorfismo }\end{array}$} & $\begin{array}{l}\text { Biotita } \rightarrow \text { Muscovita } \\
\text { Biotita } \rightarrow \text { Clorita } \\
\text { Plagioclásio } \rightarrow \text { Sericita }\end{array}$ & $\begin{array}{l}\text { Intenso } \\
\text { Praco } \\
\text { Poderado a intenso } \\
\text { Fraco a moderado }\end{array}$ \\
\hline
\end{tabular}




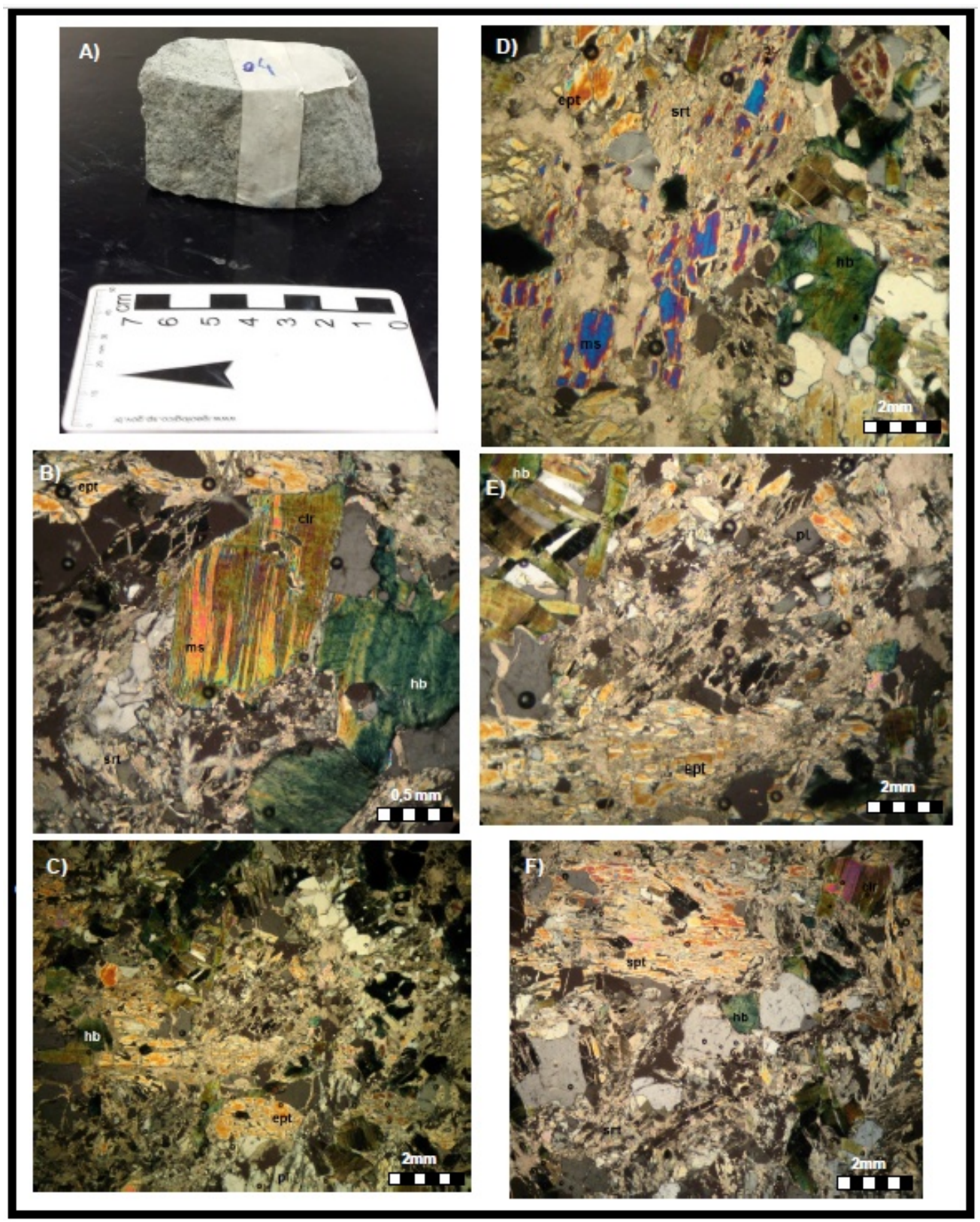

FIGURA 19 - Fotomicrografias da amostra 04. a) aspecto macroscópico do litotipo 04 (rocha alterada); b) pseudo grão de clorita transformado à partir da hornblenda e biotita, intensa saussuritização de grãos de plagioclásio gerando sericita, epidoto e carbonato, luz polarizada; c) grãos de epidoto formados pela transformação do plagioclásio; d) grão pseudomorfo de muscovita formado da substituição do plagioclásio, luz polarizada; e) grãos de serpentina formados pela transformação do piroxênio; f) forte hidrotermalização que atinge o plagioclásio, piroxênio, biotita e hornblenda, luz polarizada. Legenda: pl: plagioclásio; ms: muscovita; bt: biotita; hb: hornblenda; ept: epidoto; srt: sericita; spt: serpentina.; clr: clorita. 


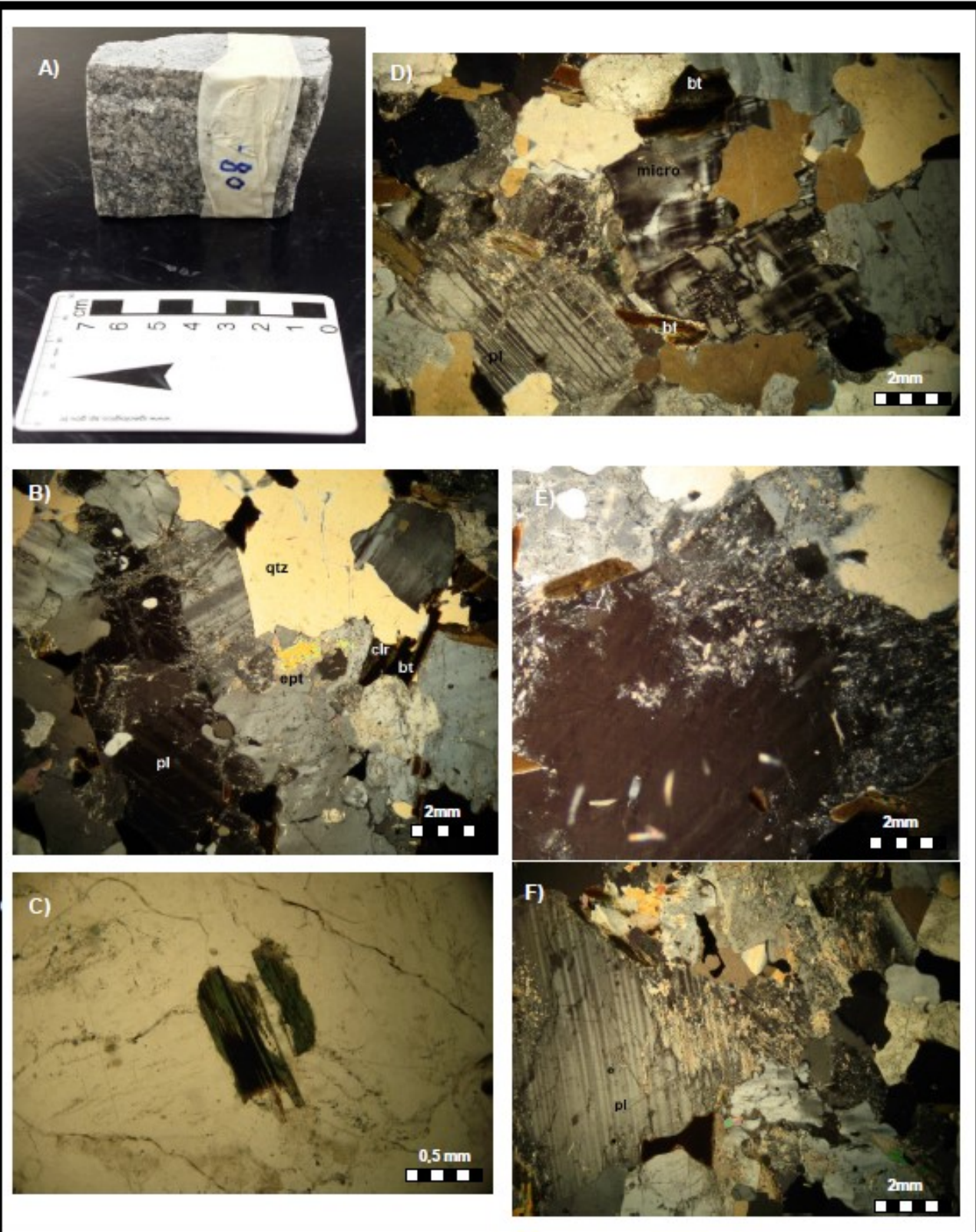

FIGURA 20 - Fotomicrografias da amostra 08. a) aspecto macroscópico do litotipo 08 (rocha sã); b) grão de plagioclásio levemente saussuritizado, biotita cloritizada, luz polarizada; c) biotita cloritizada, luz natural; d) grãos de plagioclásio alterados e grãos de muicroclina límpidos, luz polarizada; e) grãos de plagioclásio fortemente alterados para saussurita em suas bordas, rico em inclusões de apatita, luz polarizada; f) plagioclásio sofrendo intenso processo de saussuritização, luz polarizada. Legenda: pl: plagioclásio; ms: muscovita; bt: biotita; micro: microclina; ept: epidoto; qtz: quartzo. 


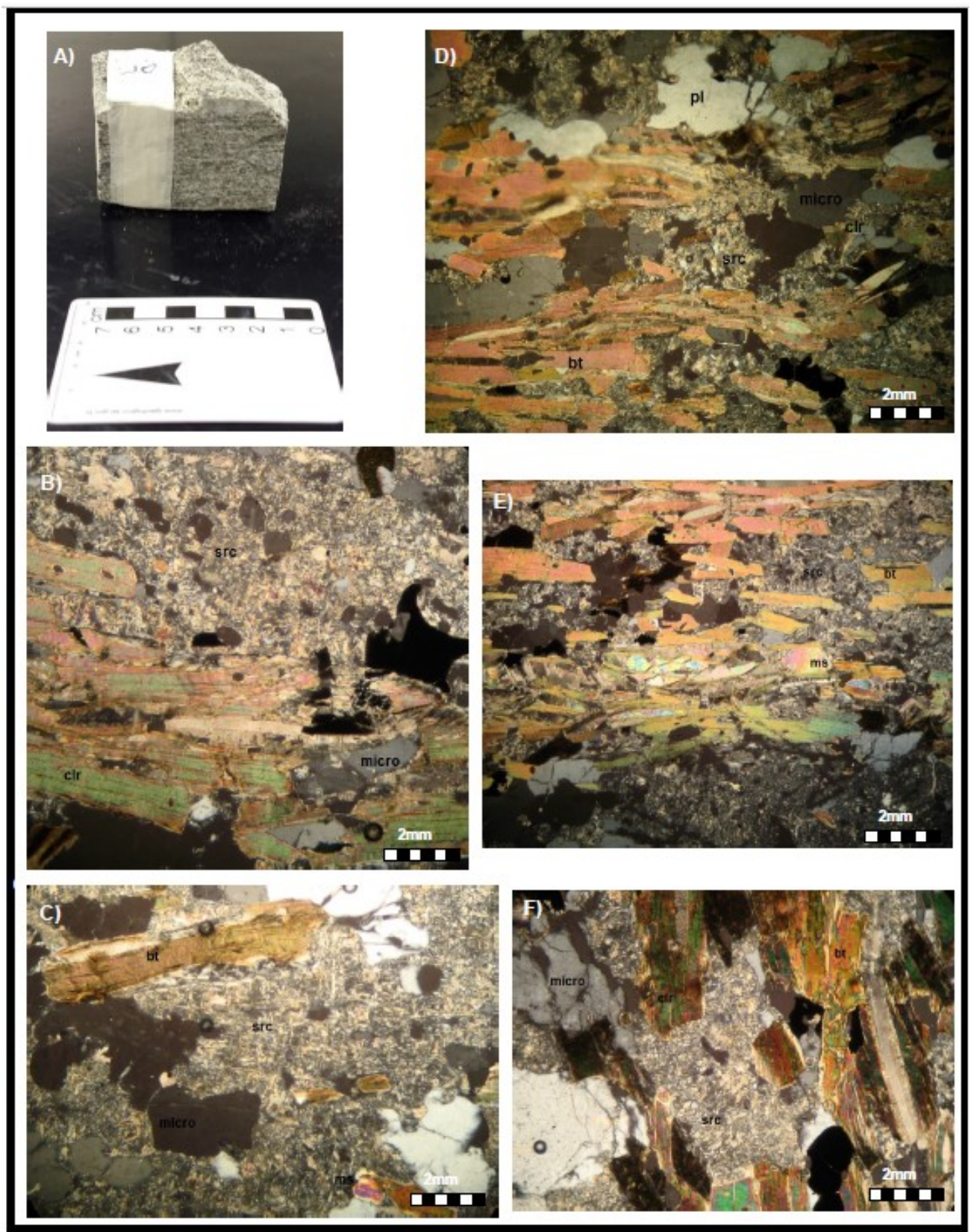

FIGURA 21- Fotomicrografias da amostra 10. a) aspecto macroscópico do litotipo 10 (rocha alterada); b) grãos de plagioclásio intensamente saussuritizados, biotita intensamente cloritizada, luz pola-rizada; c) grão de microclina limpido junto com grãos de plagioclásio intensamente alterados, luz natural; d) grãos de biotita transformados em muscovita, luz polarizada; e) grãos de biotita fortemente alterados para muscovita e grãos de plagioclásio sausuritizados, luz polarizada; f) plagioclásio sofrendo intenso processo de saussuritização, luz polarizada. Legenda: pl: plagioclásio; ms: muscovita; bt: biotita; micro: microclina; ept: epidoto; qtz: quartzo. 


\subsection{DIFRAÇÃO DE RAIOS X}

Para o estudo da mineralogia por difração de raios-x foram realizadas um total de 35 análises difratométricas, compreendendo a fração menor que 0,074 $\mathrm{mm}$, com os seus diversos tratamentos, dos quais, não foram todos incluídos por observar-se que a sua apresentação é dispensável.

As composições mineralógicas do conjunto de amostras são apresentadas na tabela 10. Através da petrografia pode-se demonstrar variados graus de alteração, entretanto somente com a difração de raios-x podem-se caracterizar as fases dos argilominerais.

TABELA 10 - Composição mineralógica das amostras analisadas.

\begin{tabular}{|c|c|c|c|}
\hline CONJUNTO & $\begin{array}{c}\text { Grau de } \\
\text { Alteração } \\
\text { (IPT, 1984) }\end{array}$ & $\begin{array}{l}\text { IDENTIFICA } \\
\text { ÇÃO DAS } \\
\text { AMOSTRAS }\end{array}$ & MINERALOGIA \\
\hline \multirow[t]{2}{*}{1} & Rocha sã & 02 & $\begin{array}{l}\text { Hornblenda, Muscovita, Biotita e } \\
\text { Quartzo }\end{array}$ \\
\hline & Rocha alterada & 24 & $\begin{array}{l}\text { Clorita, Biotita, Caulinita, Dolomita, } \\
\text { Quartzo }\end{array}$ \\
\hline \multirow{3}{*}{2} & Rocha sã & $\mathbf{0 3}$ & $\begin{array}{l}\text { Clorita, Ilita, Muscovita, Caulinita, } \\
\text { Plagioclásio, Augita, Quartzo }\end{array}$ \\
\hline & $\begin{array}{c}\text { Rocha } \\
\text { medianamente } \\
\text { alterada }\end{array}$ & 07 & $\begin{array}{l}\text { Clorita, Caulinita, Plagioclásio, Augita, } \\
\text { Quartzo }\end{array}$ \\
\hline & Rocha alterada & 11 & Caulinita, Quartzo \\
\hline \multirow{3}{*}{3} & Rocha sã & 21 & Muscovita, Biotita, Plagioclásio, Quartzo \\
\hline & $\begin{array}{c}\text { Rocha } \\
\text { medianamente } \\
\text { alterada }\end{array}$ & 20 & Muscovita, Biotita, Plagioclásio, Quartzo \\
\hline & Rocha alterada & 22 & Biotita, Plagioclásio, Microclina, Quartzo \\
\hline \multirow{3}{*}{4} & Rocha sã & 01 & Muscovita, Plagioclásio, Quartzo \\
\hline & $\begin{array}{c}\text { Rocha } \\
\text { medianamente } \\
\text { alterada }\end{array}$ & 23 & Biotita, Plagioclásio, Microclina, Quartzo \\
\hline & Rocha alterada & 25 & $\begin{array}{l}\text { Vermiculita ou Montmorilonita, Biotita, } \\
\text { Caulinita, Quartzo }\end{array}$ \\
\hline \multirow{3}{*}{5} & Rocha alterada & 04 & $\begin{array}{l}\text { Clorita, Muscovita, Caulinita, Talco, } \\
\text { Calcita, Hornblenda, Quartzo }\end{array}$ \\
\hline & Rocha sã & 08 & $\begin{array}{l}\text { Clorita, Caulinita, Biotita, Plagioclásio, } \\
\text { Microclina, Quartzo }\end{array}$ \\
\hline & Rocha alterada & 10 & $\begin{array}{l}\text { Vermiculita ou Montmorilonita, Clorita, } \\
\text { Caulinita, Biotita, Quartzo }\end{array}$ \\
\hline
\end{tabular}




\subsection{ENSAIO DE RESISTÊNCIA}

Os resultados obtidos na realização do ensaio de resistência a compressão puntiforme são demostrados na tabela 12 para os cinco conjuntos mencionados durante o trabalho.

$\mathrm{O}$ valor do fator " $\mathrm{C}$ " adotado na tabela 12 é proveniente da tabela 9, retirada da Norma da ASTM D5731-95, que relaciona o fator C com o diâmetro equivalente médio dos corpos de prova utilizados no ensaio.

TABELA 11 - Classificação proposta pela ISRM, que em função do grau de qualidade da rocha (ISRM, 1978).

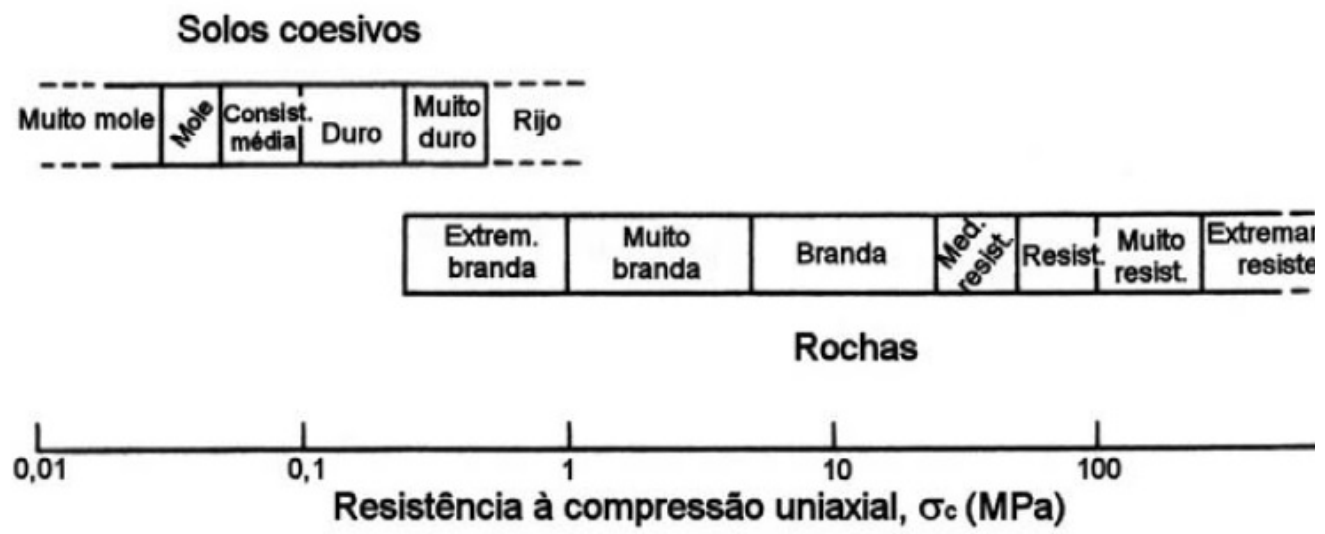

Com base na tabela 11 e nas análises de alteração propostas no tópico 4.1, procurou-se verificar uma relação entre a resistência da rocha com seus diferentes graus de alteração. 


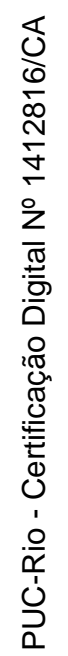

\begin{tabular}{|c|c|c|c|c|c|c|c|c|c|c|c|c|c|c|}
\hline 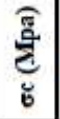 & $\begin{array}{l}10 \\
2 \\
7 \\
0 \\
07 \\
7\end{array}$ & 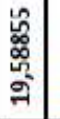 & 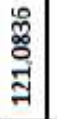 & 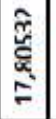 & 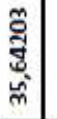 & 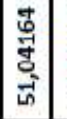 & 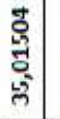 & 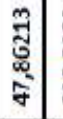 & 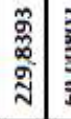 & 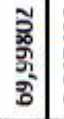 & 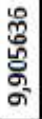 & 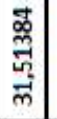 & $\begin{array}{l}\mathrm{c} \\
\vdots \\
\vdots\end{array}$ & 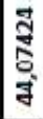 \\
\hline 0 & 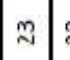 & $\approx$ & ב̃ & 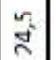 & $\begin{array}{l}0 \\
\text { वे }\end{array}$ & $\ddot{\sim}$ & $\vec{a}$ & 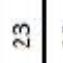 & m & 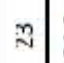 & 癸 & $\approx$ & $\cong$ & $\ddot{A}$ \\
\hline 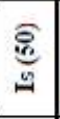 & 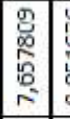 & 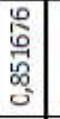 & 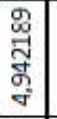 & 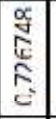 & 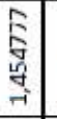 & 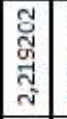 & 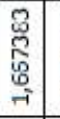 & 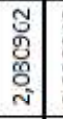 & 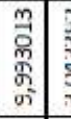 & 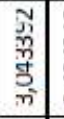 & 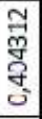 & 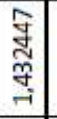 & $\begin{array}{l}\bar{E} \\
\frac{\omega}{\alpha} \\
\frac{\alpha}{\Sigma}\end{array}$ & 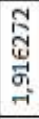 \\
\hline w & \begin{tabular}{|c|}
0 \\
0 \\
0 \\
$:$ \\
0 \\
$\stackrel{-}{-1}$ \\
\end{tabular} & $\begin{array}{l}0 \\
0 \\
0 \\
0 \\
0 \\
-1\end{array}$ & 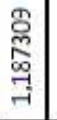 & 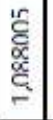 & 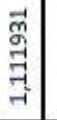 & \begin{tabular}{|l|}
0 \\
0 \\
$\circ$ \\
$:$ \\
\hdashline \\
-1
\end{tabular} & $\begin{array}{l}0 \\
0 \\
0 \\
0 \\
0 \\
0 \\
0\end{array}$ & 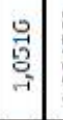 & 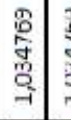 & 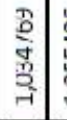 & 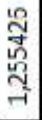 & $\begin{array}{l}\text { : } \\
\text { : } \\
\text { o. } \\
\text { o }\end{array}$ & 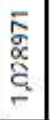 & $\begin{array}{l}10 \\
0 \\
0 \\
0 \\
0 \\
0\end{array}$ \\
\hline 产 & 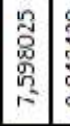 & 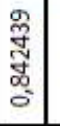 & 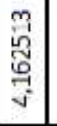 & 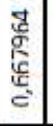 & 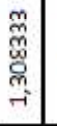 & 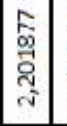 & 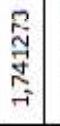 & $\begin{array}{l}\text { 落 } \\
0 \\
5 \\
- \\
-\end{array}$ & 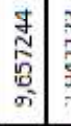 & 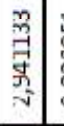 & 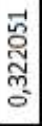 & 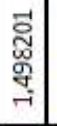 & 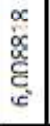 & 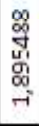 \\
\hline 的䒺 & \begin{tabular}{|l|}
0 \\
号 \\
-1
\end{tabular} & $\approx$ & \begin{tabular}{l}
00 \\
0 \\
0 \\
\hdashline
\end{tabular} & 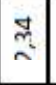 & in & \begin{tabular}{|c|} 
\\
0 \\
0 \\
in
\end{tabular} & : & \begin{tabular}{l|l} 
\\
0 \\
5 \\
5
\end{tabular} & 总: & 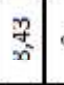 & $\sim$ & $\stackrel{m}{m}$ & $\begin{array}{l}\mathbb{Z} \\
\subseteq \\
\subseteq\end{array}$ & 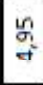 \\
\hline $\begin{array}{l}\text { 䚁 } \\
\text { 口 }\end{array}$ & 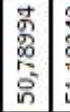 & 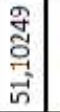 & 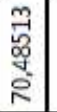 & 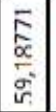 & $\begin{array}{l}\text { 志 } \\
\stackrel{9}{0} \\
\overrightarrow{0} \\
\overrightarrow{0}\end{array}$ & 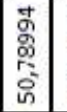 & 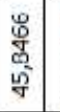 & 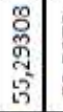 & 㝕 & 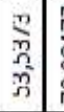 & 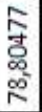 & 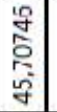 & 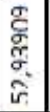 & 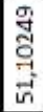 \\
\hline 气 慁 & 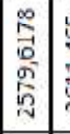 & 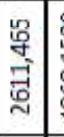 & 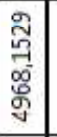 & 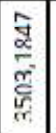 & 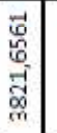 & 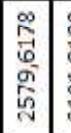 & 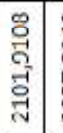 & 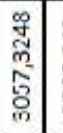 & 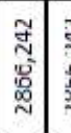 & 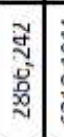 & 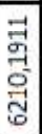 & 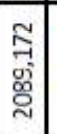 & 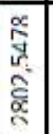 & 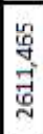 \\
\hline 䚋 & ڤิ & :̊ํํ & ষ্লি & 占 & ঃ్ & స్ำ & 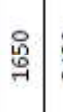 & 呆 & 品 & $\stackrel{B}{A}$ & 瓷 & 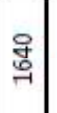 & 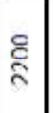 & 蒿 \\
\hline 息 & 8 & के & $\infty$ & $\tilde{\propto}$ & in & $\stackrel{-1}{8}$ & : & \& & ळి & 2 & ริ & 18 & $\bar{\propto}$ & क \\
\hline 重 & I8 & ถิ & 告 & | & in & 多 & 另 & 8 & กิ & है। & ฉ & F & ₹ & ถิ \\
\hline 产 & 年 & 7 & 8 & is & 8 & 年 & त) & f & 品 & $\begin{array}{ll}8 \\
\end{array}$ & 8 & $F$ & . & 7 \\
\hline 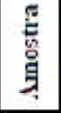 & $\checkmark$ & $\overrightarrow{a l}$ & 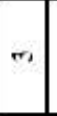 & $\therefore$ & $=1$ & ने & $\vec{A}$ & से & -12 & $\pi$ & in & + & $\propto$ & 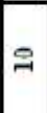 \\
\hline 善 & & & & N & & & $m$ & & & + & & & 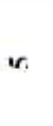 & \\
\hline
\end{tabular}

Tabela 12 - Resultados da resistência a compressão puntiforme. 


\section{DISCUSSÕES}

\subsection{CARACTERIZAÇÃO MINERALÓGICA}

\subsubsection{CONJUNTO 1}

As fases mineralógicas compostas por hornblenda, muscovita, biotita e quartzo são os principais constituintes do litotipo 02 (rocha sã). De acordo com a análise, o não aparecimento de fases minerais secundárias e o domínio de fases mineralógicas primárias apontam para a falta de mudanças em termos de transformações mineralógicas, mostrando que esse litotipo possui baixa intensidade de alteração, como foi dito na caracterização petrológica. No litotipo 24 (rocha alterada) os difratogramas revelam a presença de clorita, biotita, caulinita, dolomita e quartzo. O aparecimento dessas fases ocorre pela transformação de minerais primários em minerais secundários por alteração hidrotermal. Vale ressaltar a intensidade do pico da clorita, onde esse argilomineral surge como dominante, evidenciando talvez uma grande quantidade presente na amostra.
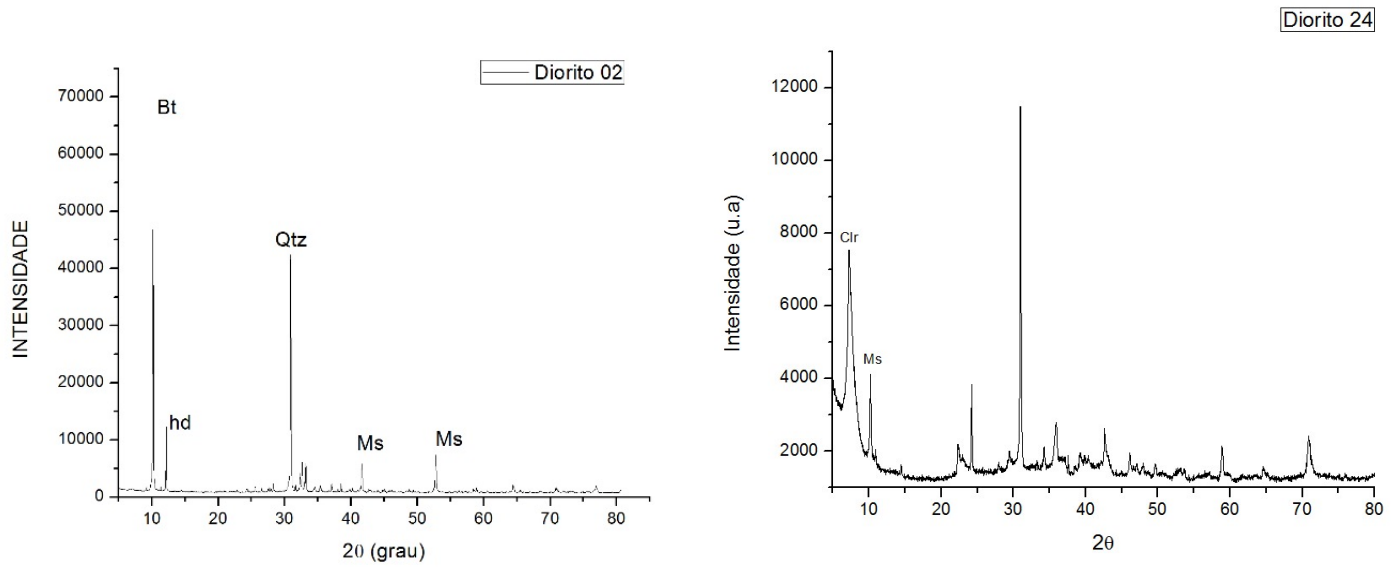

FIGURA 22- Difratogramas de Raios-X das amostras 02 e 24, indicando a presença de diversas fases de minerais secundários formados por hidrotermalismo. Legenda: bt: biotita; hd: hornblenda; qtz: quartzo; ms: muscovita; clr: clorita. 


\subsubsection{CONJUNTO 2}

O conjunto 2 são rochas formadas por diques de basalto e rocha alcalina. As fases mineralógicas compostas por clorita, ilita, muscovita, caulinita, plagioclásio, augita, quartzo são os principais constituintes do litotipo 03 (rocha sã), apesar de não estar aparentemente alterado esse tipo de rocha formada por magmas básicos e consolidados em zonas de fraturas e falhas tem grande tendência e facilidade de se alterar devido à maioria de seus minerais constituintes serem instáveis, como plagioclásios, piroxênios e anfibólios. No litotipo 07 (rocha medianamente alterada) as fases mineralógicas presente são compostas por clorita, caulinita, plagioclásio, augita, quartzo e no litotipo 11 (rocha alterada) por caulinita e quartzo. Nos litotipos 03 e 07 a difração mostra que alguns dos minerais primários permanecem no sistema constatando que o nível de alteração não é muito intenso, pois existe a presença de plagioclásio e k-feldspato. Sendo a presença de minerais de alteração hidrotermal formado restritamente por clorita (associada ao anfibólio e piroxênio) e caulinita (feldspato). Por se tratar de uma rocha alcalina alterada, o litotipo 11 é formado por caulinita como mineral dominante seguido de quartzo. Portanto independentemente do estado de alteração, os diques de basalto e traquito, devido a sua composição mineralógica, com grande quantidade de $\mathrm{Al}_{2} \mathrm{O}_{3}, \mathrm{~K}_{2} \mathrm{O}, \mathrm{Fe}_{2} \mathrm{O}_{3}, \mathrm{MgO}$ e $\mathrm{H}_{2} \mathrm{O}$ possuem maior facilidade de alteração.
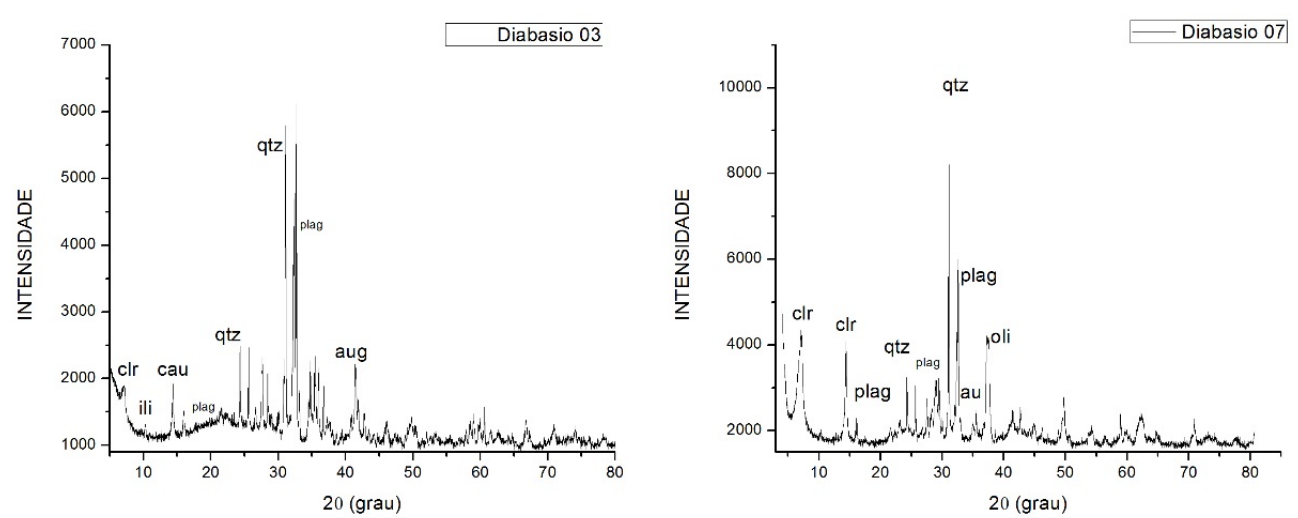
FIGURA 23- Difratogramas de Raios-X das amostras 03 e 07, indicando a presença de diversas fases de minerais secundários formados por hidrotermalismo. Radiação Co Ka (40 kV/40 mA). Legenda: clr: clorita; ili: ilita; cau: caulinita; qtz: quartzo; aug: augita; plag: plagioclásio.

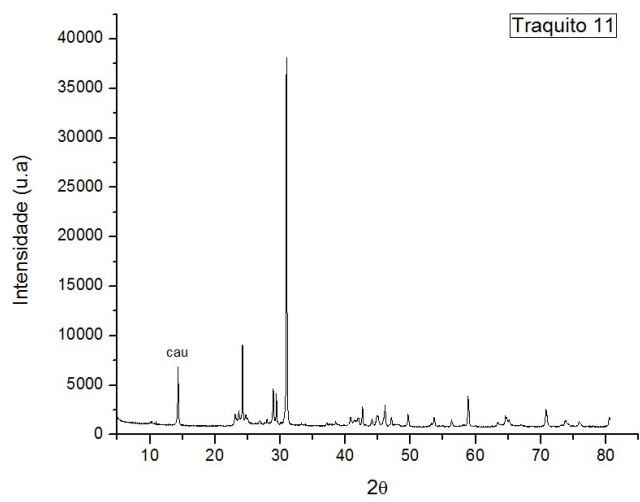

FIGURA 24- Difratograma de Raios-X da amostra 11, indicando a presença de caulinita e quartzo. Radiação Co Ka (40 kV/40 mA). Legenda: cau: caulinita.

\subsubsection{CONJUNTO 3}

O conjunto 3 formado pelos litotipos 20, 21 e 22 é composto por fases mineralógicas de muscovita, biotita, plagioclásio, quartzo e microclina. Esse conjunto não apresenta transformações significativas no que tange a alteração por hidrotermalismo. Sua paragênese é composta quase que exclusivamente por minerais primários, sendo mais resistente aos processos de alteração. A ausência de minerais secundários reforça a descrição petrográfica, mostrando que as transformações sofridas por esse litotipo são de baixa intensidade. 

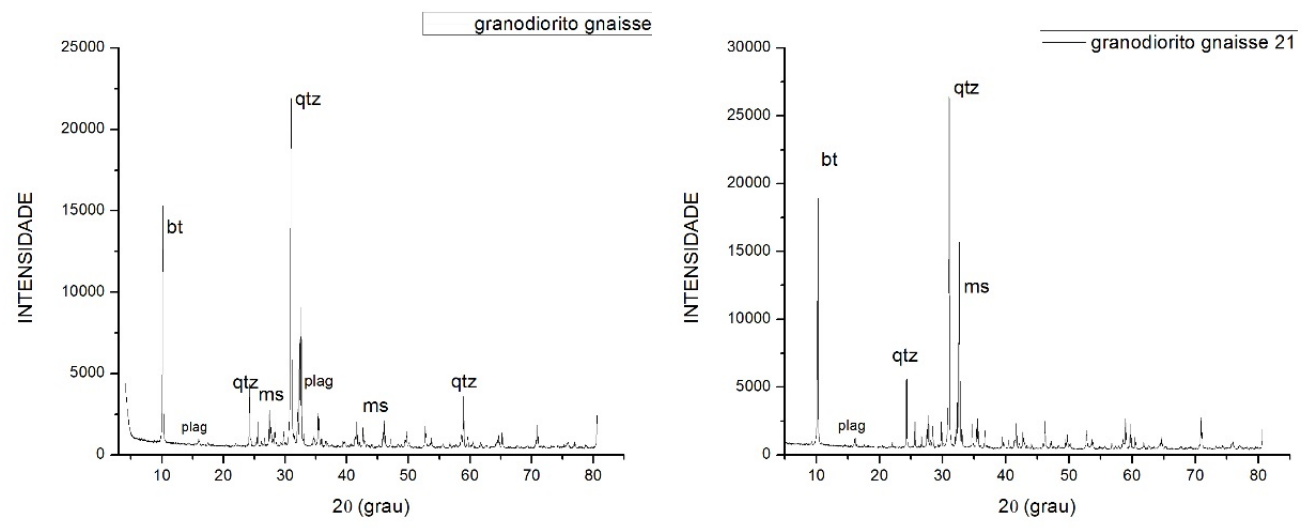

FIGURA 25- Difratogramas de Raios-X das amostras 20 e 21, indicando a presença somente de fases primárias. Radiação Co Ka $(40$ kV/40 mA). Legenda: bt: biotita; plag: plagioclásio; qtz: quartzo; ms: muscovita.

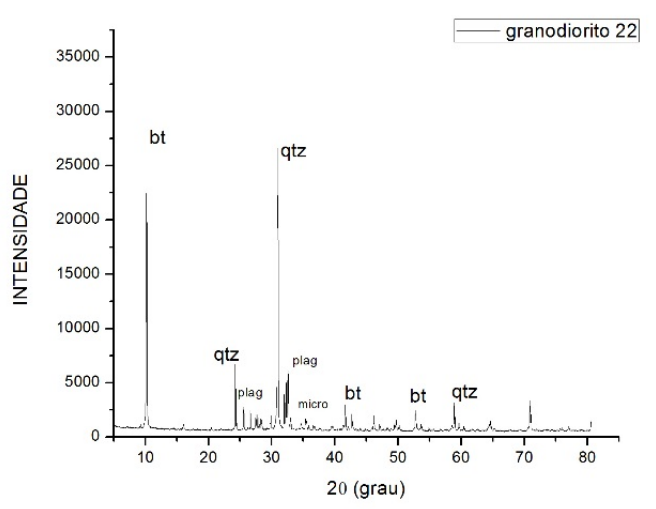

FIGURA 26- Difratograma de Raios-X da amostra 22, indicando a presença somente de fases primárias. Radiação Co Ka (40 kV/40 mA). Legenda: bt: biotita; plag: plagioclásio; qtz: quartzo; ms: muscovita; micro: microclina.

\subsubsection{CONJUNTO 4}

Os resultados obtidos do litotipo 01 (rocha sã) indicam a ocorrência de muscovita, plagioclásio e quartzo. Isso deixa claro que quando o maciço não é atacado por processos de alteração, sua mineralogia não muda, sendo sua composição mineralógica primária preservada. O litotipo 23 (medianamente alterado) é composto por biotita, plagioclásio, microclina e quartzo que também não apresenta mudanças significativas em sua estrutura primária, possuindo baixa intensidade de transformações ocorridas. Já o litotipo 25 (rocha alterada) 
composto por fases mineralógicas de vermiculita ou montmorilonita, biotita, caulinita e quartzo, mostra a forte transformação sofrida a partir do aumento do processo de alteração hidrotermal. A presença de minerais do grupo das esmectitas como resultado da alteração hidrotermal dos feldspatos, evidencia que as transformações hidrotermais foram intensas.
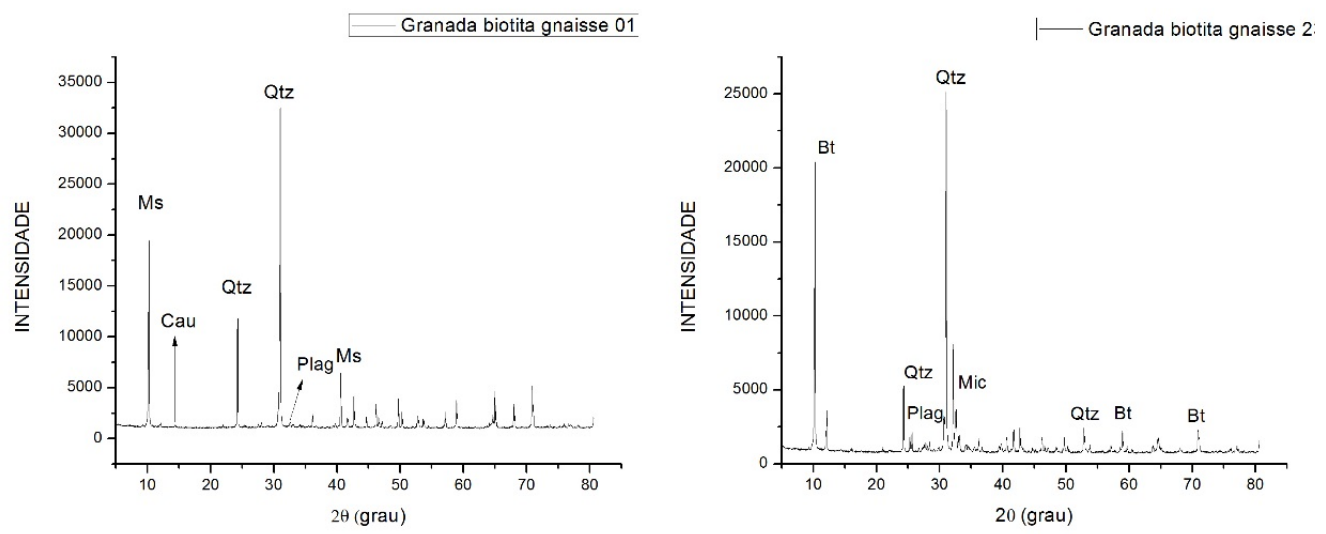

FIGURA 27- Difratogramas de Raios-X das amostras 01 e 23, indicando grande quantidade de fases primárias. Radiação Co Ka $(40 \mathrm{kV} / 40 \mathrm{~mA})$. Legenda: bt: biotita; plag: plagioclásio; qtz: quartzo; ms: muscovita; cau: caulinita; mic: microclina.

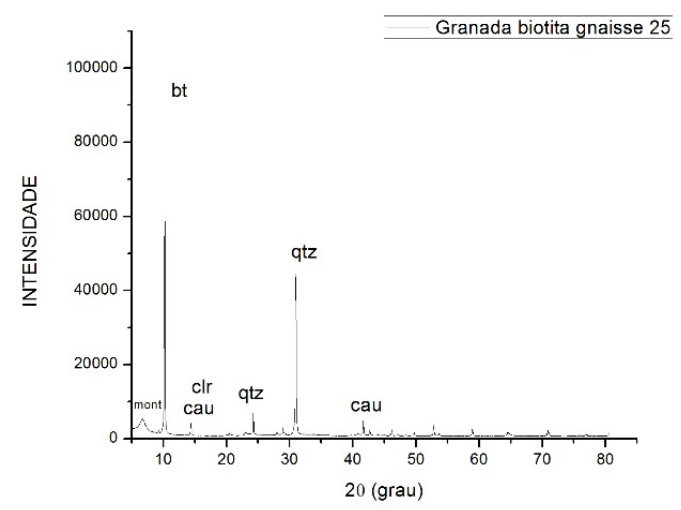

FIGURA 28- Difratograma de Raios-X da amostra 25, indicando a presença de minerais do grupo das montmorilonitas. Radiação Co Ka $(40$ kV/40 mA). Legenda: bt: biotita; clr: clorita; qtz: quartzo; cau: caulinita; mont: montmorilonita. 


\subsubsection{CONJUNTO 5}

Os resultados obtidos para o litotipo 04 (rocha alterada) indicam a ocorrência de clorita, muscovita, caulinita, talco, calcita, hornblenda, quartzo, confirmando o intenso processo de alteração hidrotermal descrito na petrografia. O aparecimento de diversas fases mineralógicas se explica pela alteração da hornblenda $\left(\mathrm{Ca}_{2}(\mathrm{Mg}, \mathrm{Fe})_{4} \mathrm{Al}\left[\mathrm{Si}_{7} \mathrm{AlO}_{22}\right](\mathrm{OH})_{2}\right)$, que é um mineral extremamente variado, com 6 ou 7 posições estruturais composto por diversos íons como $\mathrm{Ca}^{+2}$, $\mathrm{Fe}^{+2}, \mathrm{Mg}^{+2}, \mathrm{H}_{2} \mathrm{O}$, podendo se transformar em clorita $(\mathrm{Fe}, \mathrm{Mg})$, Sericita $\left(\mathrm{Na}^{+}\right)$, mica branca $\left(\mathrm{K}^{+}\right)$. O litotipo 08 formado por clorita, caulinita, biotita, plagioclásio, microclina e quartzo, apresenta grande quantidade de minerais primários, ocorre apenas clorita e caulinita que apresentam picos extremamente pequenos, evidenciando pouca quantidade desses argilominerais na amostra. O litotipo 10 é formado por vermiculita ou montmorilonita, clorita, caulinita, biotita e quartzo. A presença de minerais do grupo das esmectitas como resultado da alteração hidrotermal dos feldspatos, evidencia que as transformações hidrotermais foram intensas, assim como descritas na microscopia.
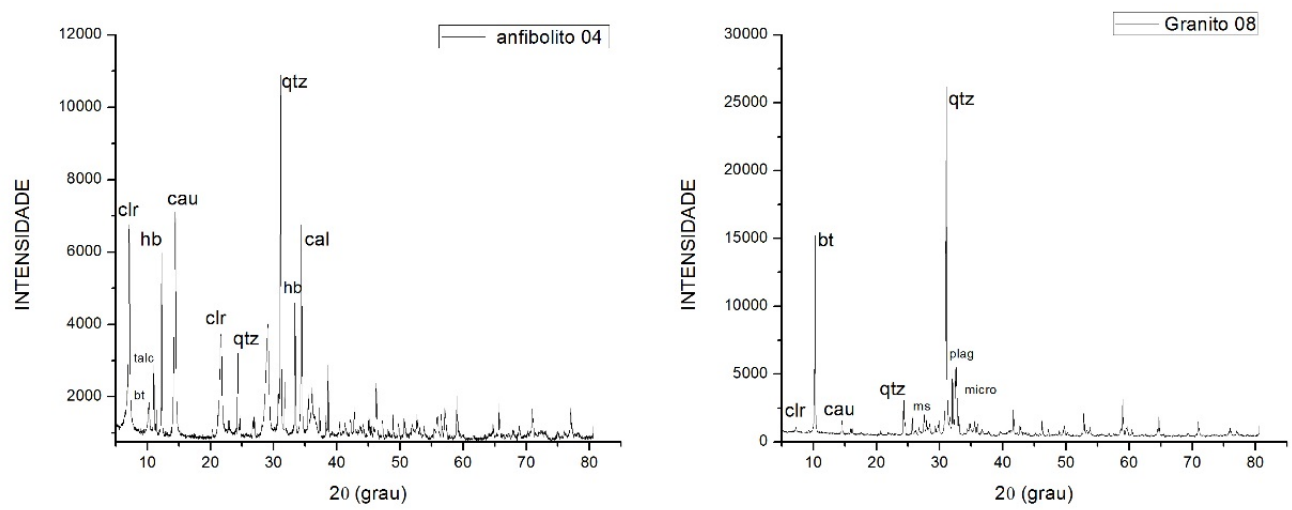


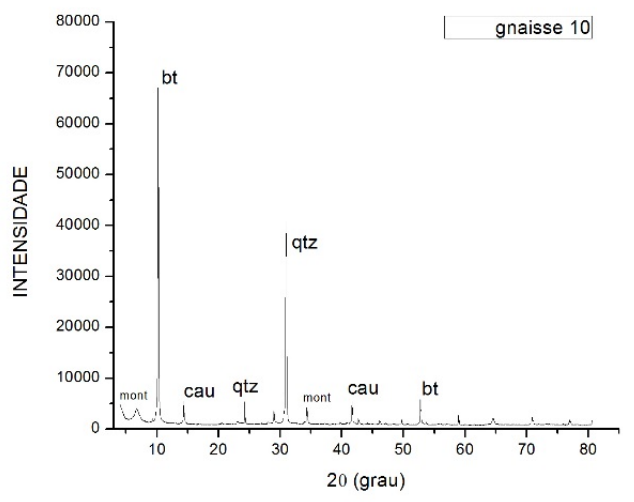

FIGURA 29- Difratogramas de Raios-X das amostras 04, 08 e 10, indicando a presença de diversas fases minerais. Radiação Co Ka $(40$ kV/40 mA). Legenda: bt: biotita; clr: clorita; qtz: quartzo; cau: caulinita; mont: montmorilonita; talc: talco; hb: hornblenda; micro: microclina.

\subsection{RESISTÊNCIA À COMPRESSÃO PUNTIFORME}

A amostra 01, de acordo com a tabela da ISRM, pode ser classificada como uma rocha muito resistente, pois apresenta um valor de resistência de 176 Mpa. A análise petrografia já havia demonstrado as poucas transformações de caráter químico-mineralógico que esse litotipo havia sofrido e como conseqüência à baixa relação minerais primários e secundários pouco afetou a trama da rocha. Entretanto a amostra 24 se mostrou branda, devido à intensa alteração mineralógica, onde fases minerais mais resistentes (feldspatos, hornblenda) foram substituídas por fases minerais menos resistentes (clorita, sericita, epidoto e calcita), refletindo na diminuição da resistência tanto no contato entre os grãos quanto na fraqueza de seus minerais.

TABELA 13 - Resistência das amostras do CONJUNTO 01

\begin{tabular}{|c|l|}
\hline AMOSTRA & $\begin{array}{l}\text { COMPRESSÃO UNIAXIAL }-\sigma c \\
(\mathrm{Mpa})\end{array}$ \\
\hline $\mathbf{0 1}$ & 176 \\
\hline $\mathbf{2 4}$ & 19,5 \\
\hline
\end{tabular}


De acordo com a tabela da ISRM, a amostra 03 pode ser classificada como uma rocha muito resistente, pois apresenta valor de resistência na ordem de $121 \mathrm{Mpa}$. $\mathrm{Na}$ análise petrografica essa rocha se mostrou pouco alterada, com poucas substituições mineralógicas, sendo a amostra maciça com poucas microfissuras preenchidas. A amostra 07 apresentava poucas substituições mineralógicas sendo as mais evidentes o aparecimento de fases de epidoto e serpentina, preservando suas características lito-estruturais, portanto seu baixo valor de resistência não está atribuído à alteração de seus minerais e sim a grande quantidade de microfraturas e microfissuras preenchidas por material amorfo de cor marrom amarelada. Já a amostra 11 se mostrou com uma resistência de 35 Mpa, sendo classificada como medianamente resistente. Por se tratar de rocha alcalina, a relação desses litotipos no campo é bastante complexa, sendo sua baixa resistência também atribuída às intensas fraturas preenchidas por material amorfo e grande quantidade de caulinita presente. Essas rochas vulcânicas apresentam em geral baixo valor de resistência, isso é devido a sua forma de ocorrência (diques subverticais) e menor espessura, facilitando a percolação de fluídos hidrotermais e diminuindo consideravelmente a sua resistência.

TABELA 14- Resistência das amostras do CONJUNTO 02

\begin{tabular}{|c|c|}
\hline AMOSTRA & $\begin{array}{c}\text { RESISTÊNCIA À COMPRESSÃO UNIAXIAL - } \sigma c \\
(\mathrm{Mpa})\end{array}$ \\
\hline $\mathbf{0 3}$ & 121 \\
\hline $\mathbf{0 7}$ & 17 \\
\hline $\mathbf{1 1}$ & 35 \\
\hline
\end{tabular}

As amostras 21, 20 e 22 são classificadas como medianamente resistentes. Tanto na descrição petrográfica quanto na análise por Difração de Raios X não foi apresentada nenhuma substituição intensa ou formação de fases de argilominerais que explicassem esse valor baixo de resistência, sendo essas amostras classificadas como rochas não alteradas pela microscopia. Como a análise petrográfica tem suas limitações, trabalhando na escala $2 \mathrm{D}$, acredita-se que a rocha apresente baixa pertinência das suas estruturas, sendo necessário fazer ensaios mais detalhados, afim de observar a real grade granular da amostra, que 
no microscópio se passa absolutamente imperceptível. Essa baixa pertinência pode estar relacionada a diversas cicatrizes na trama mineralógica nos estágios de sua formação.

TABELA 15- Resistência das amostras do CONJUNTO 03

\begin{tabular}{|c|l|}
\hline AMOSTRA & $\begin{array}{l}\text { RESISTÊNCIA À COMPRESSÃO UNIAXIAL - } \sigma \mathrm{c} \\
(\mathrm{Mpa})\end{array}$ \\
\hline $\mathbf{2 1}$ & 35 \\
\hline $\mathbf{2 0}$ & 51 \\
\hline $\mathbf{2 2}$ & 47 \\
\hline
\end{tabular}

A amostra 01 apresenta resistência de $229 \mathrm{Mpa}$, sendo classificada como extremamente resistente. Isso se deve, porque a rocha tem uma estrutura maciça, sem planos de fraturas e microfissuras e sem alterações mineralógicas pertinentes. A amostra 23 apesar de não apresentar mudanças significativas em sua estrutura primária e baixa intensidade de transformações mineralógicas, apresentou uma diminuição significativa da sua resistência, sendo classificada como medianamente resistente (69 Mpa). Esse resultado pode ser explicado, pelo fato, desse material apresentar um forte padrão de deformação e orientação de minerais planares com minerais recristalizados e fraturados, que faz com que sua resistência diminua significativamente. A amostra 25 além de possuir um forte padrão de deformação, devido a um intenso controle imposto pela foliação e presença de cisalhamentos que induziram a penetração de fluídos, apresenta intensas transformações hidrotermais (grupo das esmectitas ou vermiculita) e retrometamórficas, que diminuíram significativamente sua resistência, sendo classificada como rocha branda (9,9 Mpa).

TABELA 16 - Resistência das amostras do CONJUNTO 04

\begin{tabular}{|c|l|}
\hline AMOSTRA & $\begin{array}{l}\text { RESISTÊNCIA À COMPRESSÃO UNIAXIAL - } \sigma \mathrm{c} \\
(\mathrm{Mpa})\end{array}$ \\
\hline $\mathbf{0 1}$ & 229 \\
\hline $\mathbf{2 3}$ & 69 \\
\hline $\mathbf{2 5}$ & 9,9 \\
\hline
\end{tabular}


A amostra 04 pode ser classificada com medianamente resistente (31 Mpa), em grande parte a perda de resistência se deu a partir do aparecimento de fases secundárias como serpentina, caulinita, clorita, talco e calcita, que são minerais menos resistentes e modificam a trama da rocha. O litotipo 08 é classificado como uma rocha muito resistente (142 Mpa), suas características petrograficas mostram que é uma rocha com baixa intensidade de transformações mineralógicas, visto que poucos grãos aparecem transformados mineralogicamente. O litotipo 10 é uma rocha medianamente resistente, em grande parte pela sua anisotropia (trama microestrutural) e intensa alteração de seus minerais, onde ocorre o aparecimento de fases como montmorilonita ou vermiculita, caulinita, etc, que mudam a estrutura da rocha diminuindo assim sua resistência.

TABELA 17- Resistência das amostras do CONJUNTO 05

\begin{tabular}{|c|l|}
\hline AMOSTRA & $\begin{array}{l}\text { RESISTÊNCIA À COMPRESSÃO UNIAXIAL - } \sigma c \\
(\mathrm{Mpa})\end{array}$ \\
\hline $\mathbf{0 4}$ & 31 \\
\hline $\mathbf{0 8}$ & 142 \\
\hline $\mathbf{1 0}$ & 44 \\
\hline
\end{tabular}

\subsection{CONSIDERAÇÕES A RESPEITO DAS CLASSIFICAÇÕES GEOMECÂNICAS}

Levando em consideração as classificações geomecânicas de Bieniawski (1979) (Sitema RMR), e a de Barton et al. (1974) (Sistema Q), que determinam as propriedades do maciço rochoso, não existem motivos que impeçam ou dificultem sua utilização, a não ser um entendimento preciso dos parâmetros geológicos e geotécnico em questão.

No dimensionamento geotécnico, devido à variedade litológica do maciço, a avaliação das propriedades geotécnicas é o aspecto sobre o qual recai o maior grau de incerteza. Este fato decorre dos complexos processos geológicos envolvidos na formação dos maciços e das dificuldades da sua caracterização. No 
entanto, sem uma rigorosa caracterização dos parâmetros dos materiais envolvidos não é possível a obtenção de resultados relativamente confiáveis.

Segundo Bieniawski (1989), as classificações de maciços rochosos foram desenvolvidas para criar alguma ordem no caos que eram os procedimentos de investigação local e para fornecer ao projeto subsídios necessários. Elas não têm a intenção de substituir estudos analíticos, observações de campo e medições.

O fator principal no controle da resistência mecânica e deformabilidade é a presença de descontinuidades no maciço rochoso. Muitos autores notaram que a resistência de um maciço rochoso depende mais das descontinuidades presentes do que propriamenteda resistência da rocha intacta. Entretanto a resistência à compressão uniaxial é um parâmetro exigido nos sistemas de classificação "RMR" e "Q". Nas amostras do Conjunto 02, pode-se notar a influência das descontinuidades no resultado da resistência. Mesmo a rocha não apresentando alterações significativas que justificassem a baixa resistência, a existência de grande número de fraturas preenchidas colaborou com a sua diminuição. Entretanto, para os conjuntos 01, 04 e 05, a importância maior da queda de resistência se deu a partir dos variados graus de alteração hidrotermal e variedades na composição mineralógica, textural e estrutural. $\mathrm{O}$ conjunto 03 não apresentou alterações mineralógicas significativas e presenças de descontinuidades que justificassem a baixa resistência, sendo necessário fazer ensaios mais detalhados, a fim de observar o real comportamento reológico e mecânico da amostra.

No sistema RMR (Rock Mass Rating) o grau de alteração da rocha foi suprimido como índice básico de caracterização do maciço, uma vez que seus efeitos já se encontram embutidos nos valores de resistência a compressão simples, não sendo levado em consideração índices característicos da rocha como estrutura, grau de alteração e minerais expansivos. De certa maneira isso acontece, porém o que se tem notado é que processos de alteração hidrotermal têm contribuído para uma alterabilidade muito rápida dos maciços, onde rochas com aspecto de sã e propriedades reológicas de rochas intactas, evolue rapidamente para rochas com propriedades química, física e mineralógica de rocha alterada. Portanto o estudo da alteração hidrotermal, nesse caso, mostra-se pertinente, de modo que possa prever a intensidade dessa alteração e correlacionar com o potencial de alterabilidade do maciço. 
No sistema “Q” (Rock Tunnel Quality), Barton não leva em consideração parâmetros como a resistência da rocha intacta e espaçamento das juntas, mas leva em conta essas informações implicitamente, nos fatores RQD (índice de designação da qualidade da rocha - Rock Quality Designation) e $J_{n}$ (índice de influência do número de famílias das descontinuidades). Porém o índice que mais importa nesse trabalho é o SRF (índice de influência do estado de tensões no maciço - Stress Reduction Factor) que é a relação entre a resistência à compressão uniaxial do maciço e a tensão principal maior, procurando refletir o potencial de relaxação do maciço ao redor da escavação. Dessa maneira, Barton leva em consideração índices característicos como grau de alteração, minerais expansivos, associadosà resistência dos maciços. Apesar de levar em consideração esses parâmetros, segundo Hoek \& Brown (1980) os maciços constituídos de rochas brandas apresentam valores insatisfatórios quando aplicados o sistema "Q", enquanto que quando aplicados a maciços fraturados constituídos por rochas duras os resultados obtidos são melhores.

Devido às possíveis limitações destas classificações, as propriedades mais complexas como anisotropia e grau de alteração e o seu comportamento ao longo do tempo, não podem ser descritos por um só valor, não sendo considerado à interação entre rocha e suporte, logo se faz necessário uma abordagem muito mais detalhada dessas propriedades, por conta da incerteza sobre o real comportamento dos maciços rochosos como se demonstra nos resultados obtidos através da petrografia, mineralogia e resistência, conferindo a alteração hidrotermal um importante motivador de problemas geológicos, ligados a escavações subterrâneas, em especial a projeto de túneis. 
6

\section{CONCLUSÕES}

\subsection{CONCLUSÕES}

No que diz respeito às rochas, deve-se enfatizar que os estudos petrográficos, quando aplicados a geologia de engenharia, compreendem, além da determinação mineralógica e correta classificação da rocha, o fornecimento de informações detalhadas sobre sua granulometria tipo de alteração (hidrotermal ou intempérica) e sua intensidade na presença de minerais secundários, estado fissural, microtectonica, deformações intracristalinas, etc. Estes aspectos são importantes para o entendimento das características mecânicas e hidráulicas, visando à previsão do desempenho dos diferentes tipos rochosos sob as condições de uso a que serão submetidos.

No presente trabalho ficou demonstrado haver importantes evidências de alterações hidrotermais, por vezes intensivas nas rochas do túnel da região de Jacarepaguá. Além de ficar demonstrado que a alteração é condicionada por parâmetros ligados a gênese e história geológica dos litotipos.

A alteração hidrotermal influência tanto na mineralogia quanto na resistência dos maciços rochosos, sendo necessário um acompanhamento de forma permanente nas áreas onde ocorrem registros de alterações hidrotermais intensas, pois possuem alto potencial de alterabilidade, se tornando um desafio para as obras civis.

A petrografia indicou para os variados litotipos estudados, diversos graus de alteração, desencadeado por processos hidrotermais, apresentando mudanças na textura, mineralogia e estrutura, auxiliando no entendimento dos processos ocorridos. As mudanças mineralógicas e químicas ligadas à evolução da alteração, podem ser relacionadas a fases de substituição sucessivas que são reveladas pela textura como, por exemplo, a substituição inicial dos minerais primários de forma total ou parcial, ocorrida em todos os conjuntos estudados, pela formação de veios finos que cortam os fenocristais como visto na amostra 07 e veios mais espessos preenchidos por material amorfo (amostra 11). 
A caracterização mineralógica indicou a presença de diversas fases mineral frutos dos processos de alteração hidrotermal como montmorilonita, clorita, caulinita, muscovita, ilita, talco, além de fases minerais primárias como biotita, plagioclásio, hornblenda, microclina e quartzo. A presença de montmorilonita em duas amostras alteradas mostra a intensidade do processo de alteração hidrotermal, já que no clima tropical dificilmente se tem a formação desse mineral, evidenciando ainda mais a alteração por hidrotermalismo na região. Estudos que conduzam a localização de argilominerais expansivos de origem hidrotermal devem merecer cuidados especiais, devido a sua peculiaridade de ocorrência, já que podem trazer sérios problemas a obras de engenharia.

A resistência à compressão puntiforme mostrou que algumas amostras, classificadas à vista desarmada como rocha sã, apresentaram baixa resistência, sendo necessárias investigações petrográficas mais detalhadas. Verifica-se, portanto, uma relação estreita entre os resultados da quantificação dos processos de alteração e a resistência apresentada pelos litotipos. O fato de uma rocha se apresentar como sã a vista desarmada no campo, como por exemplo, as amostras do conjunto 3, segundo padrões geotécnicos, não quer dizer que ela esteja isenta de processos de desagregação e deslocamentos, pelo fato dela ter associada a sua gênese alguns fatores que podem desencadear uma série de problemas de caráter geotécnico.

Portanto, o projeto geotécnico, não deve ser a única ferramenta de trabalho confiável sem que seja realizada uma rigorosa caracterização dos parâmetros petrográficos, mineralógicos e geomecânicos dos materiais envolvidos. Devido à variabilidade dos maciços, a avaliação das propriedades geotécnicas é o aspecto sobre o qual recai o maior grau de incerteza, sendo necessário, tal como revelado pelas análises petrográficas e análises de resistência, uma abordagem geológica básica a fundo no entendimento dos processos geológicos a que esses maciços fazem parte.

Sendo as classificações geomecânicas um procedimento corriqueiro, à utilização em atividades geotécnicas com a finalidade de classificação de maciços rochosos, não antecipam eventuais problemas durante a obra ou até mesmo problemas pontuais. Devido a esses fatores se faz necessário, fundamentalmente, uma caracterização petrológica, mineralógica e de resistência, para real conhecimento do comportamento do maciço. 
Como apresentado nos resultados, à alteração mineralógica teve grande influência na queda de resistência do maciço rochoso. Sendo as amostras de diorito (24), Biotita granada gnaisse (25), Anfibólio (04) e biotita gnaisse (10), além dos diques, as rochas mais susceptíveis a alteração ao longo da vida útil do túnel. Desta forma pode-se concluir que pequenas abordagens geológicas podem minimizar diversos problemas de engenharia.

\subsection{SUGESTÕES PARA TRABALHOS FUTUROS}

No desenvolvimento desta dissertação, e no decorrer dos ensaios foram surgindo diferentes situações que exigiram a tomada de decisões sobre o avanço do cronograma.

Como contribuição para futuros estudos, apresentamos as seguintes sugestões:

- Verificar a partir de qual porcentagem de minerais secundários se começa a causar problemas às obras de engenharia.

- Ensaios de propriedades petrofísicas básicas, como por exemplo, densidade, porosidade e permeabilidade em condições de estresse ambiente. De modo que evidenciem a maneira como o fluído penetra no maciço, que são importantes para o entendimento do processo de alteração hidrotermal.

- Ensaios de alterabilidade para quantificar o quanto tempo levou para esse material se alterar na vida útil de uma obra. 
7

Referências bibliográficas

AIRES-BARROS, L. (1971). Alteração e alterabilidade de rochas ígneas. LNEC, Lisboa, 57p.

ASTM - Standard Test Method for Determination of the Point Load Strength Index of Rock. Designation: D 5731-95. Annual Book of ASTM Standard, 4: 494-500. 1995.

BARROSO, E. V. (1993). Estudos das características geológicas e do comportamento geotécnico de um perfil de intemperismo em leptinito. Dissertação de mestrado, Universidade Federal do Rio de Janeiro, instituto de geociências, Rio de Janeiro, Brasil. 251 p.

BARTON, N; LIEN, R \& LUNDE, J. (1974) - Engineering Classification of Rock Masses for The Design of The Tunnel Support. Rock Mechanics, Vol. 6, $\mathrm{n}^{\circ} 4$, pp. 189-236.

BIENIAWSKI, Z. T. (1975). The Point Load Test in Geotechnical Practice. Eng. Geol., Sept., 1975, pp. 1-11.

BIENIAWSKI, Z. T. (1979). The Geomechanics Classification in Rock Engineering Applications. Proc. 4th Int. Congress Rock Mechanics, ISRM, Montreux, Vol. 2, pp. 41-48.

BIENIAWSKI, Z. T. (1989). Engineering Rock Mass Classifications. A complete Manual for Engineers and Geologists in Mining, Civil and Petroleum Engineering. John Wiley \& Sons, 251p. 
BRITO, A. T. A. (1981). Estudo químico e mineralógico de um perfil de alteração de gnaisse migmatítico do campo experimental da PUC-RJ, gávea, Rio de Janeiro. Dissertação de Mestrado, DEC, PUC-Rio. 286 p.

BROCH, E. \& FRANKLIN, J. A. (1972). The point load strength test. International Journal of Rock Mechanics and Mining Science, 9, 669-697.

CAMPOS, D. J. P. (2007). Processos de alteração hidrotermal em rochas [ígneas e metamórficas e suas implicâncias geotécnicas: $O$ estudo do caso do túnel do Joá - Rio de Janeiro, RJ. Monografia - Departamento de Geociênciais da UFRRJ, Rio de Janeiro, RJ, p. 50.

CARVAlHO, J. B. Q. (1997). Fundamentos da Mecânica dos solos. $1^{\circ}$ ed., Campina Grande - Paraíba, Ed. Marcone. 310p.

CARVALHO, N. S. (1998). Os condicionantes geológico-geotécnicos na ocupação do espaço subterrâneo no município do Rio de Janeiro. Dissertação de mestrado, Universidade Federal do Rio de Janeiro, instituto de geologia, Rio de Janeiro, Brasil. 116 p.

COSTA, A. P. L. (2007). Alterabilidade e Caracterização Tecnológica dos Gnaisses Enderbíticos da Porção Norte do Estado do Ceará com Aplicação no Setor de Rochas Ornamental. Tese de doutorado, Instituto de geociências, Universidade Estadual Paulista, Rio Claro. 214p.

ESTEVES, A. DUARTE, B.P. \& PORTO JR. R. (2001) - Evolução Metamórfica dos Gnaisses da Parte Leste do Maciço da Pedra Branca, Rio de Janeiro, RJ. Simp. Geol. Sudeste. CD-ROM.

FARRAN, J.; THÉNOZ, B. (1965). L'alterabilité des roches, ses facteurs as prévision. Annales de L'Inst. Tech. Du Batim. et des Trav. Publ., Paris, no 215, pp.1534-1548. 
FRAZÃO, E. B., (2012). Alteração de rochas como critério de seleção de agregados $2^{\circ}$ edição. São Paulo. Associação Brasileira de Geologia de Engenharia e Ambiental. 2012. 123p.

FROLOVA, J. LADYGIN, V. Rychagov, S. ZUKHUBAYA, D. (2006). Effects of hydrothermal alterations on physical and mechanical properties of rocks in the Kuril-Kamchatka island arc. Engineering Geology 183: 80-95.

GEO-RIO (2001). Levantamento dos acidentes do Túnel do Joá. Relatório final.

GUIDICINI, G., NIEBLE, C. M. and CORNIDES, A. T., (1973). Analysis of point load test as a method for preliminary geotechnical classification of rocks. Bull. Int. Assoc. Eng. Geol., 7: 37-52.

GRIM, R. E. (1968). Clay Mineralogy. New York, McGraw Hill Book Company, $2^{\mathrm{a}}$ edição.

HASEGAWA, S., Yoshida, Y., Akagi, W. Tamura, E., Kanbara, D. (2006). Rock mass characterization for hidrotermal alteration and landsliding, IAEG, paper number 580 .

HOEK, E. e BROWN, E.T. (1980): Underground excavations in rock. Institution of Mining and Metallurgy, London 1980, 527 pp.

ICDD, International Centre for Diffraction Data. PDF-2 dataset, 2006.

ISRM. (1973). Suggested Method for Determining the point load strength index. ISRM Committee on laboratory test, Document 1, pp. 8-12.

ISRM (1978) - Suggested methods for the quantitative description of descontinuities in rock masses.Int. J. Rock Mechanics Min. Sci. Geomech.Abstr., Vol. 15, pp. 319-368. 
JUNIOR, M. S. D. (1983). Influência dos argilominerais na expansibilidade das rochas. Dissertação de Mestrado, DEC, PUC-Rio. 167p.

MAIA, P. C. A. (2001). Avaliação do comportamento geomecânico e de alterabilidade de enroncamentos. Dissertação de mestrado, departamento de Eng. Civil da PUC-Rio, Rio de Janeiro, Brasil 326p.

MITCHELL, J. K. (1976). Fundamentals of soil behavior. John Willey and sons.Berkeley, CA.

MINETTE, E. (1982). Quantificação geomecânica e de alterabilidade de um diorito. Dissertação de mestrado, departamento de Eng. Civil da PUC-Rio, Rio de Janeiro, Brasil 243 p.

MISAS, C. M. E. (2010). Evolução magmática, alteração hidrotermal e gênese da mineralização de ouro e cobre do Palito, Província Aurífera do Tapajós (PA). Dissertação de mestrado, Universidade de São Paulo, instituto de geociências, São Paulo, Brasil. 179 p.

NISHIMOTO, S., YOSHIDA, H. (2009). Hydrothermal alteration of Deep fractured granite: Effects of dissolution and precipitation. Lithos. Volume 115, Issues 1-4, pages 153-162.

OLIVEIRA, E. P. (2006). Caracterização bio-físico-quimico-mineralógica e micromorfológica de um perfil de alteração de granito-gnaisse de Curitiba, PR. Dissertação de Mestrado, DEC, PUC-Rio. 197p.

PIRAJNO, F. (1992). Hydrothermal Mineral Deposits, Principles and Fundamental Concepts For the Exploration Geologist. Spring-Verlag, New York. 709p.

POLIVANOV, H. (1998). Caracterização química, mineralógica, física e geotécnica de perfis de alteração desenvolvidos de gnaisse. Tese de Doutorado, 
Universidade Federal do Rio de Janeiro, instituto de geociências, Rio de Janeiro, Brasil. 387 p.

PORTO Jr., R. (2004). Petrogênese das Rochas do Maciço da Pedra Branca. Rio de Janeiro, RJ. Tese de Doutorado. IG/UFRJ. 231p.

REED, M. H. (1997). Hydrothermal alteration and its relationship to ore fluid composition. In: BARNES, H. L., ed. Geochemistry of hydrothermal ore deposits. 3 ed. New York: J. Wiley, 1997. P. 303-365.

ROSE, A. W.; BURT, D. M. Hydrothermal alteration. (1979). In: BARNES, H. L., ed. Geochemistry of hydrothermal ore deposits. 2 ed. New York: J, Wiley, 1979. P 173-235.

RUSNAK, J., MARK, C. (2000). Using the point load test to determine the uniaxial compressive strength of coal measure rock. In Proceedings of the 19th international conference on gorund control in mining. Morgantown, Wv: West Virginia University pp. 362-371.

SAUNDERS, M. K. and FOOKES, P. G. (1970). A review of the relationship of rock weathering and climate and its significance to foundation engineering. Eng. Gel. 4, 289-325.

SERRA JUNIOR, E.; OJIMA, L. M. (1998). Classificação de maciços rochosos. Geologia de Engenharia. São Paulo. ABGE. Ofina de Texto. P .15-38.

SERTÃ, H. B. C. (1986). Aspectos Geológicos e Geotécnicos do solo residual do campo experimental II da PUC-RJ. Dissertação de Mestrado, DEC, PUCRio. $185 p$.

SILVA, A. M. C. (1997). Caracteristicas químicas e mineralógicas de um perfil de intemperismo em leptinito. Dissertação de mestrado, Universidade Federal do Rio de Janeiro, instituto de geociências, Rio de Janeiro, Brasil. 177 p. 
SILVA, A. U. (2011). Caracterização e análise de resistência para as rochas dos emboques do túnel da grota funda - Rio de Janeiro, RJ. Monografia Departamento de Geociênciais da UFRRJ, Rio de Janeiro, RJ, p. 55.

SILVA, L.C. \& CUNHA, H.C. DA S. (2001). Geologia do Estado do Rio de Janeiro: texto explicativo do mapa do Estado do Rio de Janeiro, Brasília, CPRM.

TU, X. B., JIAN, B., WANG, S. J., BIAN, H. Y., WANG, J. \&“LI, S. G. (2005). Swelling bahavior induced by alteration in granite and its implications on underground excavation. Tunnelling and underground space technology 20 (4): 378-389.

THURO, K. and SCHOLZ, M. (2003). Deep weathering and alteration in granites-a product of coupled processes, in Proceedings of the International Conference on Coupled T-H-M-C Processes in Geosystems: Fundamentals, Modeling, Experiments and Applications (GeoProc 03). Royal Institute of Technology (KTH).

VALERIANO, C. M. et al. (2012). Geologia e recursos minerais da folha Baía de Guanabara SF.23-Z-B-IV, estado do Rio de Janeiro, escala 1:100.000. Belo Horizonte: CPRM, 2012. 156p.

VELDE, B. (1992). Introduction to clay minerals. Chemistry, origins, uses and environmental significance.Chapmen Hall, London.198p.

WERNICK, E. (2004). Rochas magmáticas: conceitos fundamentais e classificação modal, química, termodinâmica e tectônica. Ed. Unesp. São Paulo.

ZHANG, Y., GUO, C., QU, Y., SONG, Y. (2010). Engineering geological properties of altered rocks and implications for railway construction in the Sanjiang orogenic belt, Southwest China. Bulletin of engineering Geology and the Environment. Volume 70, Issue 1. Pages 143-152. 